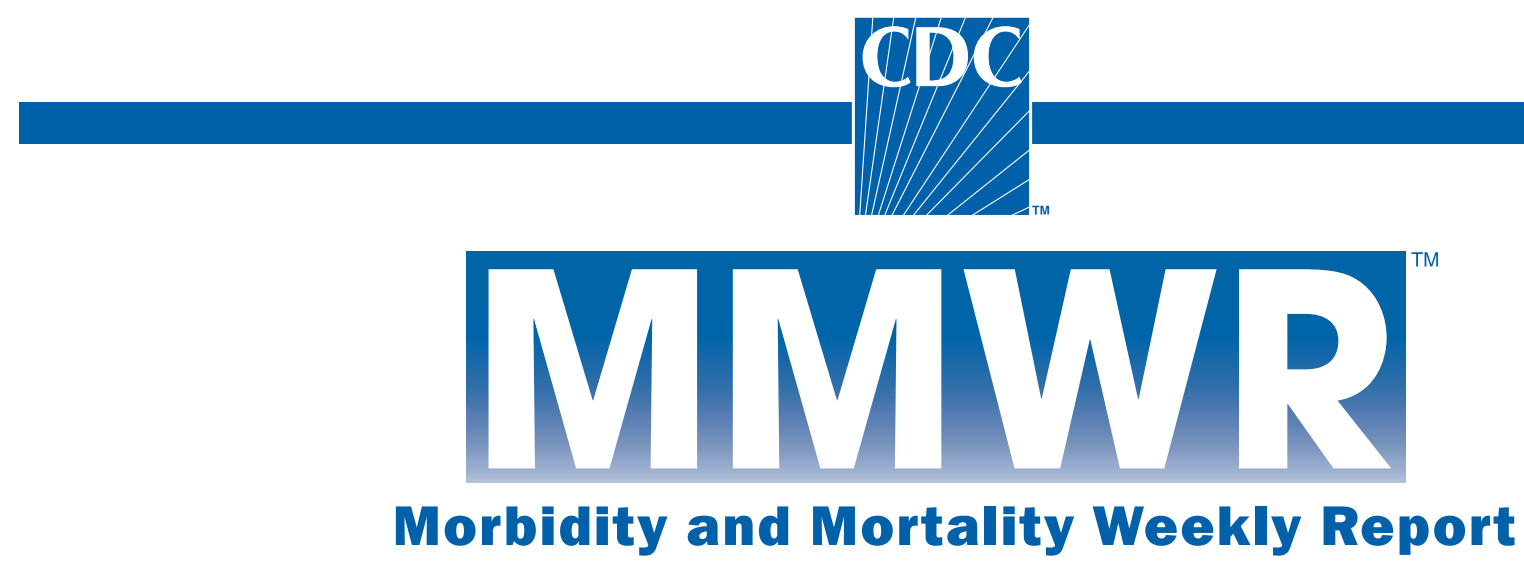

Weekly

April 7, 2006 / Vol. 55 / No. 13

\title{
Homicides Among Children and Young Adults - Puerto Rico, 1999-2003
}

Interpersonal violence causes substantial morbidity and mortality worldwide and poses a considerable economic burden, equivalent to $4 \%-5 \%$ of the gross national product in certain countries (1). The Commonwealth of Puerto Rico is a U.S. territory with a 2004 population of approximately 3.9 million (2). In Puerto Rico, homicides were the 12th leading cause of death overall in 2003, ranking fifth among males and 15 th among females (3). This report summarizes an analysis of death certificate data on violent deaths of children and young adults in Puerto Rico during 1999-2003, which determined that $93 \%$ of homicide victims aged $<30$ years were young males, the most common method of homicide was assault by firearm discharge, and the rate of homicide among males aged 2529 years increased during the period. To address this problem, the Puerto Rican government has initiated a comprehensive strategy that includes enhancing an integrated surveillance system for fatal and nonfatal assault, supporting research on interpersonal violence, and establishing local prevention programs (e.g., violence prevention curricula in selected schools).

The University of Puerto Rico Center for Hispanic Youth Violence Prevention obtained annual data from the Puerto Rico Health Department, Division of Statistics (3) on homicides among persons aged $<30$ years in Puerto Rico during 1999-2003 and examined the data by age group, sex, and method (e.g., assault by firearm discharge or assault by sharp object) for each year (4). Homicide was defined as death resulting from an injury purposefully inflicted by another person (including legal intervention) for which the underlying cause listed on the death certificate corresponded to codes X85-Y09, Y35, and
Y89.0* of the International Statistical Classification of Diseases and Related Health Problems, 10th Revision (5). Death rates were determined on the basis of the decedent's county of residence. Categorization of rural versus urban was based on application of codes developed by the U.S. Department of Agriculture to the 2000 U.S. Census population assessment. Intercensal population estimates for 1999-2003 obtained from the Census Office of the Puerto Rico Planning Board were used to calculate rates (G). Rates based on

\footnotetext{
*X85: assault (homicide) by drugs, medicaments, and biological substances; X86: assault (homicide) by corrosive substance; X87: assault (homicide) by pesticides; X88: assault (homicide) by gases and vapors; X89: assault (homicide) by other specified chemicals and noxious substances; $\mathrm{X} 90$ : assault (homicide) by unspecified chemical or noxious substance; X91: assault (homicide) by hanging, strangulation, and suffocation; X92: assault (homicide) by drowning and submersion; X93: assault (homicide) by handgun discharge; X94: assault (homicide) by rifle, shotgun, and larger firearm discharge; X95: assault (homicide) by other and unspecified firearm discharge; X96: assault (homicide) by explosive material; X97: assault (homicide) by smoke, fire, and flames; X98: assault (homicide) by steam, hot vapors, and hot objects; X99: assault (homicide) by sharp object; Y00: assault (homicide) by blunt object; Y01: assault (homicide) by pushing from high place; Y02: assault (homicide) by pushing or placing victim before moving object; Y03: assault (homicide) by crashing of motor vehicle; Y04: assault (homicide) by bodily force; Y05: sexual assault (homicide) by bodily force; Y06: neglect and abandonment; Y07: other maltreatment syndromes; Y08: assault (homicide) by other specified means; Y09: assault (homicide) by unspecified means; Y35: legal intervention; Y89.0: sequelae of legal intervention.
}

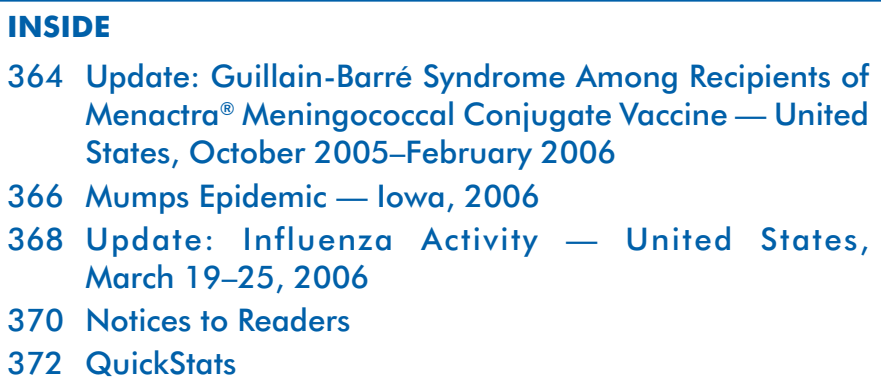
Menactra ${ }^{\circledR}$ Meningococcal Conjugate Vaccine - United States, October 2005-February 2006

366 Mumps Epidemic - lowa, 2006

368 Update: Influenza Activity - United States, March 19-25, 2006

370 Notices to Readers

372 QuickStats 
The MMWR series of publications is published by the Coordinating Center for Health Information and Service, Centers for Disease Control and Prevention (CDC), U.S. Department of Health and Human Services, Atlanta, GA 30333.

\section{SUGGESTED CITATION}

Centers for Disease Control and Prevention. [Article title]. MMWR 2006;55:[inclusive page numbers].

Centers for Disease Control and Prevention

Julie L. Gerberding, MD, MPH

Director

Dixie E. Snider, MD, MPH

Chief Science Officer

Tanja Popovic, MD, PhD

Associate Director for Science

\section{Coordinating Center for Health Information and Service}

Steven L. Solomon, MD Director

National Center for Health Marketing

Jay M. Bernhardt, PhD, MPH Director

Division of Scientific Communications Judith R. Aguilar (Acting) Director

Mary Lou Lindegren, MD Editor, MMWR Series

Suzanne M. Hewitt, MPA Managing Editor, MMWR Series

Douglas W. Weatherwax (Acting) Lead Technical Writer-Editor

Stephanie M. Neitzel Jude C. Rutledge Writers-Editors

Lynda G. Cupell

Malbea A. LaPete

Visual Information Specialists

Quang M. Doan, MBA

Erica R. Shaver Information Technology Specialists

Notifiable Disease Morbidity and 122 Cities Mortality Data Patsy A. Hall Deborah A. Adams Lenee Blanton fewer than 20 deaths or with a coefficient of variation of $>30 \%$ are considered unstable and should be interpreted with caution.

During 1999-2003, of 3,613 total homicides in Puerto Rico, $2,303(64 \%)$ occurred among persons aged $<30$ years. Of these homicides, 2,148 (93\%) were among males. The homicide rate for males was 14 times the rate for females ( 47.7 per 100,000 population versus 3.5 , respectively) (Table). For both males and females, the homicide rate was highest among persons aged 20-24 years (126.8 and 7.6, respectively).

Among both male and female homicide victims aged $<30$ years, firearms were the most common method $(90.1 \%$ of males, $65.4 \%$ of females), followed by assault with a sharp object ( $4.6 \%$ of males, $21.2 \%$ of females), and all other methods (5.3\% of males, $13.5 \%$ of females). Among persons aged 15-29 years, homicides were most common during July and August; $91.2 \%$ of homicides occurred in urban areas, although only $60.3 \%$ of homicide victims were urban residents.

Homicide rates varied by age group. Although homicide rates among persons aged 15-19 years declined slightly (from 36.3 per 100,000 in 1999 to 31.2 per 100,000 in 2003), rates among persons aged $25-29$ years increased $47.6 \%$ (from 45.0 to 66.4) (Figure), especially among males (from 82.9 to 129.8 , an increase of $56.7 \%)$.

Reported by: B Mirabal, MD, I Rodríguez, MS, CN Vélez, PhD, Univ of Puerto Rico Center for Hispanic Youth Violence Prevention, San Juan, Puerto Rico. A Crosby, MD, J Hoffman, PhD, Div of Violence Prevention, National Center for Injury Prevention and Control, CDC.

Editorial Note: Homicide rates among persons aged 15-29 years in the United States declined from 1993 to 2003 (from 21.6 per 100,000 to 13.4 per 100,000$)$ but remain the second leading cause of death in this age group (1). In Puerto Rico, however, homicides are the leading cause of death for the same age group, and the rate increased during 1999-2003 (from 49.8 in 1999 to 54.1 in 2003) (3). During 1999-2003, persons aged $<30$ years accounted for $43 \%$ of the population of Puerto Rico but approximately $64 \%$ of all homicide vic-

TABLE. Number and rate* of homicides among children and young adults, by sex and age group of victim - Puerto Rico, 1999-2003

\begin{tabular}{lrrrrrrrrr}
\hline & \multicolumn{3}{c}{ Male } & & \multicolumn{2}{c}{ Female } & & \multicolumn{2}{c}{ Total } \\
\cline { 2 - 3 } \cline { 8 - 9 } Age group (yrs) & No. & Rate & & No. & Rate & & No. & Rate \\
\hline $0-9$ & 19 & 1.3 & & 16 & 1.1 & & $\mathbf{3 5}$ & $\mathbf{1 . 1}$ \\
$10-14$ & 10 & 1.3 & & 6 & 0.8 & & $\mathbf{1 6}$ & $\mathbf{1 . 1}$ \\
$15-19$ & 455 & 57.9 & & 27 & 3.6 & & $\mathbf{4 8 2}$ & $\mathbf{3 1 . 2}$ \\
$20-24$ & 945 & 126.8 & & 57 & 7.6 & & $\mathbf{1 , 0 0 2}$ & $\mathbf{6 6 . 8}$ \\
$25-29$ & 719 & 106.8 & & 49 & 7.0 & & $\mathbf{7 6 8}$ & $\mathbf{5 5 . 8}$ \\
Total & $\mathbf{2 , 1 4 8}$ & $\mathbf{4 7 . 7}$ & & $\mathbf{1 5 5}$ & $\mathbf{3 . 5}$ & & $\mathbf{2 , 3 0 3}$ & $\mathbf{2 7 . 3}$ \\
\hline
\end{tabular}

${ }^{*}$ Per 100,000 population. Rates based on fewer than 20 deaths are considered unstable. 
FIGURE. Homicide rate* among persons aged 15-29 years, by age group of victim — Puerto Rico, 1999-2003

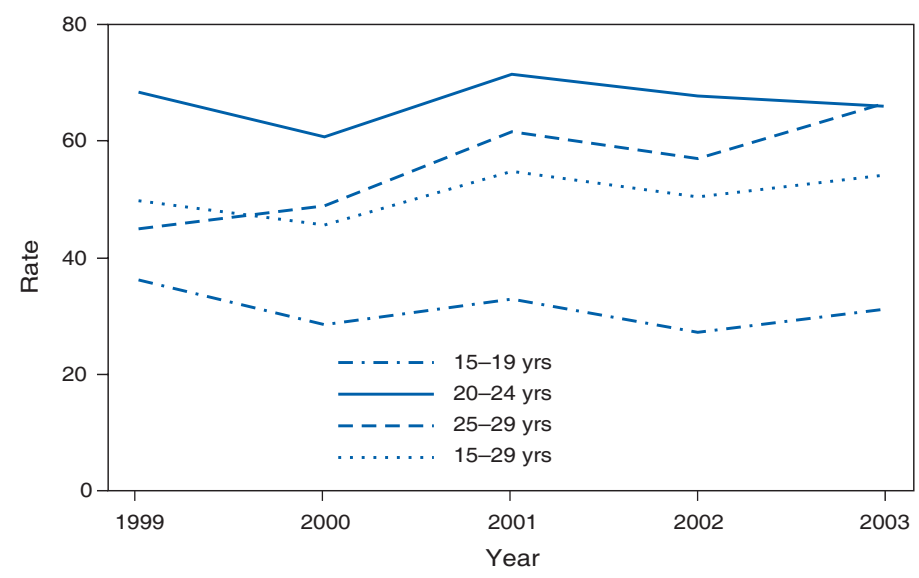

* Per 100,000 population.

tims. Homicides occurred predominantly among males and in urban areas, and by firearms. The persistence of high homicide rates among young persons in Puerto Rico indicates a critical need for addressing potential contributors to interpersonal violence.

The findings in this report are subject to at least three limitations. First, the data were obtained from death certificates, which lack information about the circumstances, perpetrator, and victim/perpetrator relationship. This limits the ability to describe certain types of homicides (e.g., child maltreatment versus peer assault) and their unique risk factors; age and sex distributions of homicides are likely to differ by type of homicide. Second, death certificates provide little or no information about socioeconomic status, an important risk factor for interpersonal violence (1). Finally, death certificates might misclassify some homicides as other causes of death (7).

Recent studies indicate that approximately $90 \%$ of the estimated 520,000 homicides worldwide in 2000 occurred in lowto middle-income countries, including in Central and South America and the Caribbean (1). In these regions, high levels of poverty and income inequality between communities are major contributors to social and family violence (7). A recent study of homicides in Puerto Rico during 1990-1999 concluded that the risk of dying from homicide in Puerto Rico was among the highest in the world (23.2 per 100,000, compared with a worldwide average of 10.7 per 100,000) $(1,8)$; homicide rates in Puerto Rico correlated directly with high population density (8).

Research on risk and protective factors has identified several potential contributors to youth interpersonal violence in Puerto Rico, including neighborhood environment, rapid urbanization, political violence, organized criminal activity, illegal drug use, and drug trafficking (7). Studies of violence in Central and South America also have demonstrated the influence of individual factors (e.g., age, sex, or exposure to aggression) and household factors (e.g., history of family violence or household beliefs that support violent solutions to conflict) on interpersonal violence ( 7 ). An understanding of these factors should aid in the development of violence prevention programs for Puerto Rican communities.

Multiple efforts have been initiated in Puerto Rico to address the problem of interpersonal violence. Since 2000, the Center for Hispanic Youth Violence Prevention has participated in the development, implementation, and evaluation of strategies to address violence among Hispanic youth from a public health perspective. Activities include conducting research on risk and protective factors, training health and education professionals in youth violence prevention competencies (e.g., recognizing at-risk youth), and adapting an evidence-based violence prevention curriculum for cultural appropriateness and evaluating its implementation with students in a high-risk community in San Juan (9).

The Puerto Rican government also has implemented several strategies to address the problem of violence, including distributing the World Report on Violence and Health (1) to community leaders and government health organizations, instituting increased police surveillance in high-crime neighborhoods, installing video equipment to monitor streets and alert law enforcement to criminal activity, and allocating resources to enhance forensic investigations. In addition, the governor-appointed Commission for Violence Prevention and the Puerto Rico Health Department are designing and implementing a pilot surveillance project that merges public health and criminal justice data on violent deaths, especially those among adolescents and young adults; the findings will be used to guide future public health initiatives to reduce and prevent violent deaths in Puerto Rico. These monitoring and data analysis activities will need to be integrated with comprehensive prevention strategies that include ongoing assessment of community needs, multisectoral collaboration, youth participation, and early intervention in the lives of at-risk youth to address risk and protective factors regarding interpersonal violence.

\section{References}

1. Krug ED, Dahlberg LL, Mercy JA, Zwi AB, Lozano R, eds. World report on violence and health. Geneva, Switzerland: World Health Organization; 2002.

2. US Census Bureau. 2004 population estimates, Census 2000. Available at http://www.census.gov.

3. Puerto Rico Health Department. Violent death rates by years, 1962 2003. San Juan, PR: Auxiliary Secretariat for Planning and Development, Division of Statistical Analysis; 2005.

4. Puerto Rico Health Department. Deaths by homicides, procedures, age group, and gender. San Juan, PR: Auxiliary Secretariat for Planning and Development, Division of Statistical Analysis; 2005. 
5. World Health Organization. International statistical classification of diseases and related health problems, 10th revision. Second ed. Geneva, Switzerland: World Health Organization; 2004.

6. Puerto Rico Health Department. Population by age and sex groups. San Juan, PR: Auxiliary Secretariat for Planning and Development, Division of Statistical Analysis; 2005.

7. Buvinic M, Morrison A, Shifter M. Violence in Latin America and the Caribbean: a framework for action. Washington, DC: InterAmerican Development Bank; 1999.

8. Rodríguez J, Irizarry A. El homicidio en Puerto Rico: características y nexos con la violencia [Homicides in Puerto Rico: characteristics and nexuses with violence]. San Juan, PR: Universidad Carlos Albizu; 2003.

9. Thornton TN, Craft CA, Dahlberg LL, Lynch BS, Baer K. Best practices of youth violence prevention: a sourcebook for community action. Atlanta, GA: US Department of Health and Human Services, CDC, National Center for Injury Prevention and Control; 2000.

\section{Update: Guillain-Barré Syndrome Among Recipients of Menactra ${ }^{\circledR}$ Meningococcal Conjugate Vaccine - United States, October 2005-February 2006}

In October 2005, a possible association between GuillainBarré Syndrome (GBS) and receipt of meningococcal conjugate vaccine (i.e., meningococcal polysaccharide diphtheria toxoid conjugate vaccine $\left[\right.$ Menactra $\left.\left.{ }^{\circledR}\right]\right)^{*}(\mathrm{MCV} 4)$ was reported (1). GBS is a serious neurologic disorder involving inflammatory demyelination of the peripheral nerves. At the time of the first report, five confirmed cases of GBS after receipt of MCV4 had been reported to the Vaccine Adverse Events Reporting System (VAERS). During the 4 months since, three additional confirmed cases of GBS have been reported. This report describes two of these recent cases and provides additional data collected through February 2006. Because available evidence neither proves nor disproves a causal relation between MCV4 and GBS, further monitoring and studies are ongoing within VAERS and the Vaccine Safety Datalink (VSD). CDC continues to recommend use of MCV4 for persons for whom vaccination is indicated (1); the additional reported cases have not resulted in any change to that recommendation.

\section{Case Reports}

Brief clinical and epidemiologic descriptions of two of the newly reported cases follow. The third case is undergoing detailed clinical investigation but meets the provisional case definition for GBS. ${ }^{\dagger}$

\footnotetext{
*Sanofi Pasteur (Swiftwater, Pennsylvania).

${ }^{\dagger}$ Available at http://www.cdc.gov/nip/vacsafe/concerns/gbs/gbs_case_defs.pdf.
}

Case 1. On August 8, 2005, a male aged 19 years from Arizona was vaccinated with MCV4. Approximately 25 days later, he experienced numbness and tingling in his hands and feet, followed by weakness in his legs, difficulty running, and decreased dexterity in his hands. In the month before neurologic symptom onset, he had no defined episode of respiratory or gastrointestinal illness. He had traveled to Mexico twice during the preceding 3 months. Electrophysiology studies revealed a diffuse neuropathic process with both demyelinating and axonal features, consistent with GBS. Testing for Epstein-Barr virus capsid IgG and IgM antibodies was negative. Testing for cytomegalovirus IgG and IgM antibodies also was negative, as were serologic studies for hepatitis $\mathrm{A}, \mathrm{B}$, and $\mathrm{C}$ to rule out other probable causes of GBS. The patient was treated with intravenous immunoglobulin. At follow-up examination 8 weeks after onset, he had fully recovered.

Case 2. On November 4, 2005, a male aged 17 years from Ohio received MCV4. Eleven days later, he experienced numbness and tingling in his right foot, followed by the same symptoms in the left foot, which progressed proximally during the next 5 days. He also described a neck hyperextension injury sustained while playing sports 2 days before the start of sensory symptoms and sore throat and congestion 1 day before sensory symptoms. He had no gastrointestinal illness during the 6 weeks before hospital admission, which occurred 6 days after symptom onset. Cervical spine radiographs revealed no fractures; magnetic resonance imaging (MRI) of the spine revealed mild enhancement along the surface of distal cord and lumbar nerve roots, consistent with GBS. Nerve conduction studies also were consistent with GBS. Polymerase chain reaction (PCR) assays for enterovirus were negative, as were tests for Mycoplasma pneumoniae IgG and IgM. The patient was treated with intravenous immunoglobulin. At follow-up examination 2 weeks after admission, he had completely recovered.

In the two cases described in this report, the period from MCV4 vaccination to symptom onset was less than 6 weeks. This is the time window of elevated risk noted for GBS after administration of certain other vaccines (2).

To determine whether the reporting rate of GBS after MCV4 vaccination was higher than the expected incidence rate of GBS for the appropriate age group population, the reporting rate was calculated by dividing the eight confirmed GBS cases with onset within 6 weeks of vaccination by the number of vaccine doses distributed as provided by the manufacturer (approximately 3.77 million doses of MCV4 were distributed during March 2005-February 2006). The eight cases were divided by the 3.77 million distributed doses to provide the reporting rate for GBS after MCV4. The expected incidence rate of GBS was estimated from a multistate hospital discharge 
database (Health Care Utilization Project). ${ }^{\S}$ For the years 2000-2003, the incidence rate of GBS among persons aged 11-19 years was estimated to be 1.4 per 100,000 population per year or 0.17 per 100,000 population during a 6-week period. Therefore, the ratio of the reporting rate of GBS after MCV4 vaccination to the expected incidence rate was 1.4 ( $95 \%$ confidence interval $=0.7-2.8)$, suggesting that the occurrence of eight cases of GBS within 6 weeks of MCV4 administration is similar to what might be expected to occur by chance alone.

As part of the investigation, other possible causes of GBS, such as Campylobacter jejuni, were assessed. C. jejuni is a leading cause of gastroenteritis globally and the most frequent antecedent pathogen in GBS (3). No evidence of $C$. jejuni was observed in any of the eight cases reported; however, many C. jejuni infections are asymptomatic. No serum samples from GBS cases reported after MCV4 vaccination were available for testing. To further assess the possibility that $C$. jejuni was a precipitating cause, unpublished data were collected and analyzed from all five state health departments involved in initial GBS case reports to VAERS (Arizona, New Jersey, New York, Ohio, and Pennsylvania). Despite an expected seasonal peak of GBS cases from June to October 2005 (CDC, unpublished data, 2005), none of the involved states reported outbreaks of C. jejuni during this period.

Reported by: Center for Biologics Evaluation and Research, Food and Drug Admin. Arizona State Health Dept. New Jersey Dept of Health and Senior Svcs. New York State Dept of Health. Columbus City Health Dept, Columbus, Ohio. Pennsylvania Dept Health. Immunization Safety Office, National Immunization Program; National Center for Infectious Diseases; F Soud, PhD, EIS Officer, CDC.

Editorial Note: In October 2005, CDC and the Food and Drug Administration (FDA) alerted health-care providers about a possible association between GBS and MCV4 and encouraged reporting of adverse events to VAERS (1). Since that time, three additional confirmed cases of GBS with onset within 6 weeks of MCV4 vaccination have been reported. However, even with these reported cases, the reported incidence remains similar to the expected incidence. In addition, three other cases of GBS have been reported, with symptom onsets at $>6$ weeks (107 days, 116 days, and 125 days) after vaccination with MCV4; these three cases were not included in calculation of GBS rates. Because VAERS is a voluntary reporting system, the completeness of reporting of GBS remains unknown. Only three cases were reported since October 2005, suggesting that MCV4 might not be causally related to GBS. The background incidence rate of GBS is one to two cases per 100,000 population. However, the timing of

\footnotetext{
${ }^{\$}$ Available at http://www.ahrq.gov/hcupnet.
}

onset of neurologic symptoms within 2-5 weeks of vaccination is still a concern.

Additional preliminary data from VSD, a collaborative project between CDC and eight managed care organizations in the United States, have not identified GBS cases in MCV4 recipients. However, VSD has a limited ability to detect rare health events such as GBS. To further evaluate any potential risk, additional controlled studies of GBS after MCV4 are being planned.

The case definition developed for the initial investigation has been refined by an extended working group of the Brighton Collaboration, ${ }^{* *}$ an international voluntary collaboration of scientists. The Clinical Immunization Safety Assessment Network, ${ }^{\dagger \dagger}$ in collaboration with CDC, continues to research and conduct standardized clinical evaluation of affected vaccinees to better understand the pathophysiology of select adverse events after vaccination, such as GBS. In response to the evaluation of the reported cases to VAERS, Sanofi Pasteur and FDA updated the Menactra vaccine package insert to list previous GBS as a contraindication and provide a warning of the temporal relation between GBS and MCV4 (4).

In October 2005, CDC recommended continuing use of MCV4 for persons for whom vaccination is recommended; the additional cases reported in this update do not affect that recommendation (1). In December 2005, the Global Advisory Committee on Vaccine Safety also recommended no change in MCV4 vaccination policies (5).

The Advisory Committee on Immunization Practices has recommended that persons with a history of GBS should not be vaccinated with MCV4 unless they are at elevated risk for meningococcal disease (6). Persons at elevated risk for meningococcal disease include first-year college students living in dormitories, military recruits, travelers to areas in which meningococcal disease is hyperendemic or epidemic, microbiologists who are routinely exposed to isolates of Neisseria meningitidis, patients with anatomic or functional asplenia, and patients with terminal complement deficiency. Information regarding the current investigation should be shared with adolescents and caregivers before MCV4 vaccination. A Vaccine Information Statement and fact sheet noting the information on the reported GBS cases is available at http://www. cdc.gov/nip/publications/vis/default.htm. An updated fact sheet for health-care workers is available at http://www. cdc.gov/nip/vacsafe/concerns/gbs/menactra.htm. CDC continues to recommend that health-care workers and any other persons aware of adverse events associated with MCV4 or any other vaccination report to VAERS cases of GBS or any other

\footnotetext{
${ }^{9}$ Available at http://www.cdc.gov/nip/vacsafe/vsd.

** Information available at http://www.brightoncollaboration.org.

$\dagger^{\dagger \dagger}$ Available at http://www.vaccinesafety.org/cisa/index.htm.
} 
clinically significant adverse events. Reports may be submitted securely online at http://www.vaers.hhs.gov or by fax at 877-721-0366. Reporting forms and additional information is available at telephone, 800-822-7967.

\section{References}

1. CDC. Guillain-Barré syndrome among recipients of Menactra ${ }^{\circledR}$ meningococcal conjugate vaccine-United States, June-July 2005. MMWR 2005;54:1023-5.

2. Schonberger LB, Bergman DJ, Sullivan-Bolyai JZ, et al. Guillain-Barré syndrome following vaccination in the National Influenza Immunization Program, United States, 1976-1977. Am J Epidemiol 1979;110: 105-23.

3. Takawashi M, Koga M, Yokoyama K, Yuki N. Epidemiology of Campylobactor jejuni isolated from patients with Guillain-Barré and Fisher syndrome in Japan. J Clin Microbiol 2005;43:335-9.

4. Food and Drug Administration. Meningococcal (sero groups A,C,Y, and W 135) polysaccharide toxoid conjugate vaccine, Menactra ${ }^{\circledR}$. Available at http://www.fda.gov/cber/label/mpdtave102105LB.pdf.

5. World Health Organization. Conjugate meningococcal vaccine and Guillain-Barré Syndrome. Wkly Epidemiol Rec 2006;2:13-20.

6. CDC. Prevention and control of meningococcal disease: recommendations of the Advisory Committee on Immunization Practices (ACIP). MMWR 2005;54(No. RR-7):1-21.

\section{Mumps Epidemic - lowa, 2006}

On March 30, this report was posted as an MMWR Dispatch on the MMWR website (http://www.cdc.gov/mmwr).

In the United States, since 2001, an average of 265 mumps cases (range: 231-293 cases) have been reported each year,* and in Iowa, an average of five cases have been reported annually since $1996 .{ }^{\dagger}$ However, in 2006, by March 28, a total of 219 mumps cases ${ }^{\S}$ had been reported in Iowa (Figure 1), and an additional 14 persons with clinically compatible symptoms were being investigated in three neighboring states (11 in Illinois, two in Nebraska, and one in Minnesota) in what has become the largest epidemic of mumps in the United States since 1988 (1). This report summarizes and characterizes the ongoing mumps epidemic in Iowa, the public health response, and recommendations for preventing further transmission.

\footnotetext{
*Data available at http://www.cdc.gov/mmwr/preview/mmwrhtml/mm5511 md.htm\#tab1.

$\dagger$ Data available at http://www.idph.state.ia.us/adper/common/pdf/cade/decades.pdf.

$\$$ Includes 150 confirmed, nine probable, and 60 suspect cases. Case definitions were modified from Council of State and Territorial Epidemiologists/CDC mumps case definitions for use in this outbreak. Confirmed: case that meets the clinical case definition (i.e., unilateral or bilateral tender, self-limited, swelling of the parotid or other salivary gland, lasting $>2$ days and without other apparent cause) and is laboratory confirmed (i.e., by a positive IgM test result or positive viral culture) or epidemiologically linked to a confirmed case. A confirmed case can be asymptomatic if a mumps viral culture is positive. Probable: case that meets the clinical case definition but has noncontributory or no serologic or virologic testing and is not epidemiologically linked to a confirmed or probable case. Suspect: case with a positive IgM test result but no confirmation of the clinical definition.
}

FIGURE 1. Number* of mumps cases, ${ }^{\dagger}$ by week of onset lowa, 2006

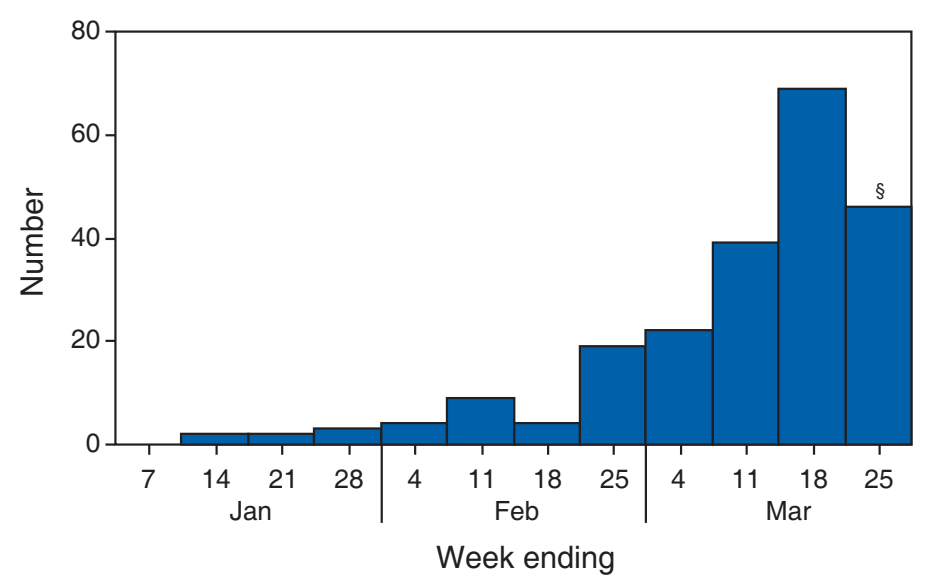

${ }^{*} \mathrm{~N}=219$.
Includes confirmed, probable, and suspect cases. Case definitions were
modified from Council of State and Territorial Epidemiologists/CDC mumps
case definitions for use in this outbreak. Confirmed: case that meets the
clinical case definition (i.e., unilateral or bilateral tender, self-limited, swell-
ing of the parotid or other salivary gland, lasting $>2$ days and without
other apparent cause) and is laboratory confirmed (i.e., by a positive IgM
test result or positive viral culture) or epidemiologically linked to a con-
firmed case. A confirmed case can be asymptomatic if a mumps viral
culture is positive. Probable: case that meets the clinical case definition
but has noncontributory or no serologic or virologic testing and is not
epidemiologically linked to a confirmed or probable case. Suspect: case
with a positive IgM test result but no confirmation of the clinical definition.
\$Provisional data; cases being assessed for the week ending March 25,2006 .

Mumps is an acute viral infection characterized by fever and nonsuppurative swelling of the salivary glands; an estimated $20 \%-30 \%$ of cases are asymptomatic. Complications can include inflammation of the testicles or ovaries, meningitis/ encephalitis, spontaneous abortion, and deafness. During the prevaccine era, nearly everyone in the United States experienced mumps, and $90 \%$ of cases occurred among children aged $<15$ years. In 1977, Iowa law mandated 1 dose of measles, mumps, and rubella (MMR) vaccine for entry to public schools; in 1991, the mandate became 2 doses. For the 2004-05 school year, $97 \%$ of children entering school in Iowa had received 2 doses of MMR vaccine (2).

The first reports to the Iowa Department of Public Health (IDPH) of mumps-like illness occurred in December 2005 at a university in eastern Iowa, where several students with glandular swelling were tested; two tested positive for mumpsspecific IgM antibodies. In mid-January 2006, an isolate from an unrelated patient was cultured and identified as mumps virus at the University Hygienic Laboratory (Iowa's state public health laboratory). Viral isolates were sent to CDC, and the mumps strain was identified as genotype G. By midFebruary, active surveillance had been initiated in seven geographic areas, including the campuses of the three largest universities in Iowa. 
Of the 219 cases reported in Iowa, the median patient age was 21 years (range: $3-85$ years), with $48 \%$ of patients aged 17-25 years (Figure 2); 30\% (34 of 114) were known to be college students. Of the 133 patients with investigated vaccine history, $87(65 \%)$ had documentation of receiving 2 doses, $19(14 \%) 1$ dose, and eight (6\%) no doses; vaccine status could not be documented in 19 (14\%) patients. Among the 114 patients for whom symptomatic information was available, the most common symptoms were parotitis in 94 (83\%) patients, submaxillary/sublingual gland swelling in $46(40 \%)$, fever in 41 (36\%), and sore throat in $36(32 \%)$; average duration of illness was 5.1 days. Six (5\%) patients reported complications (e.g., orchitis); one suspected case of encephalitis is being investigated. As of March 28, 2006, investigators had determined that only $36(16 \%)$ of the 219 cases were linked epidemiologically (i.e., a source of infection was identified), suggesting frequent unapparent transmission.

The source of the Iowa epidemic is unknown; however, the United Kingdom (UK) experienced a recent mumps epidemic that peaked during 2005 with approximately 56,000 cases and a high attack rate among young adults (3). The mumps strain in the UK epidemic also was identified as genotype $G$ (4), and the UK epidemic has been linked to a 2005 mumps outbreak in the United States (5).

To educate health-care professionals in Iowa regarding the epidemic and mumps, information has been distributed via Iowa's Health Alert Network (HAN), in weekly electronic newsletters, and via frequent conference calls. The IDPH website $^{\mathbf{I}}$ has provided biweekly updates, county case counts, fact sheets, and guidance to local health departments and health-care facilities on case investigations. IDPH recommendations include 1) requesting at least 5 days of isolation for all patients (quarantine is not being used), 2) ensuring that students and staff members on all Iowa college campuses have had 2 doses of MMR or are immune from mumps (6), 3) assessing vaccination status of all health-care professionals in Iowa and offering vaccination where appropriate (7), and 4) sending all specimens collected from possible cases to University Hygienic Laboratory for testing.

Despite control efforts and a highly vaccinated population, this epidemic has spread across Iowa and potentially to neighboring states. Ongoing investigations will focus on identifying actual vaccine coverage on college campuses, potential modes of mumps transmission, and the effectiveness of 1 or 2 doses of MMR.

Reported by: Local Iowa public health departments; University Hygienic Laboratory, Iowa City; P Quinlisk, MD, M Harris, MPH, T Thornton, Iowa Dept of Public Health. L Flamigni, MD, EIS Officer, CDC.

\section{References}

1. CDC. Mumps surveillance-United States, 1988-1993. In: Surveillance Summaries, August 11, 1995. MMWR 1995;44(No. SS-3).

2. Iowa Department of Public Health, Bureau of Disease Prevention and Immunization. Immunization audit 2004-2005 school year, K-12 summary report by county. Des Moines, IA: Iowa Department of Public Health.

3. CDC. Mumps epidemic-United Kingdom, 2004-2005. MMWR 2006;55:173-5.

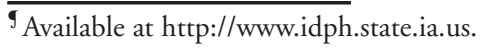

FIGURE 2. Number ${ }^{\star}$ of mumps cases, ${ }^{\dagger}$ by age of patient - lowa, 2006

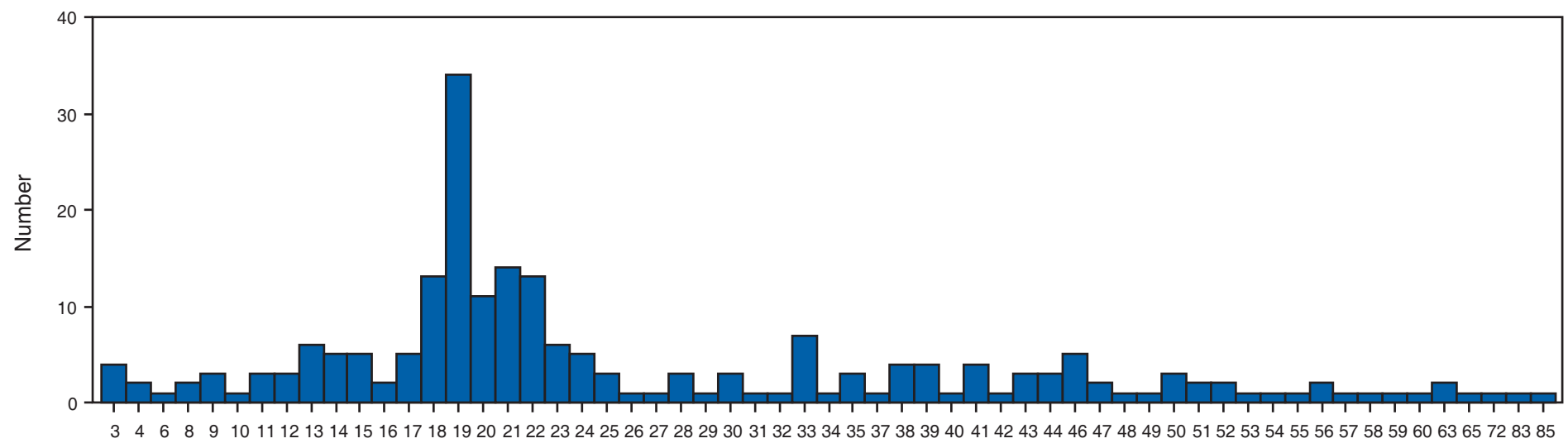

Age (yrs)

\footnotetext{
${ }^{*} \mathrm{~N}=215$; ages of four patients are unknown.

${ }^{\dagger}$ Includes confirmed, probable, and suspect cases. Case definitions were modified from Council of State and Territorial Epidemiologists/CDC mumps case definitions for use in this outbreak. Confirmed: case that meets the clinical case definition (i.e., unilateral or bilateral tender, self-limited, swelling of the parotid or other salivary gland, lasting $>2$ days and without other apparent cause) and is laboratory confirmed (i.e., by a positive lgM test result or positive viral culture) or epidemiologically linked to a confirmed case. A confirmed case can be asymptomatic if a mumps viral culture is positive. Probable: case that meets the clinical case definition but has noncontributory or no serologic or virologic testing and is not epidemiologically linked to a confirmed or probable case. Suspect: case with a positive IgM test result but no confirmation of the clinical definition.
} 
4. Jin L, Brown DW, Litton PA, White JM. Genetic diversity of mumps virus in oral fluid specimens: application to mumps epidemiological study. J Infect Dis 2004;189:1001-8.

5. CDC. Mumps outbreak at a summer camp-New York, 2005. MMWR 2006;55;175-7.

6. CDC. Measles, mumps, and rubella—vaccine use and strategies for elimination of measles, rubella, and congenital rubella syndrome and control of mumps: recommendations of the Advisory Committee on Immunization Practices (ACIP). MMWR 1998;47(No. RR-8).

7. CDC. Immunization of health-care workers: recommendations of the Advisory Committee on Immunization Practices (ACIP) and the Hospital Infection Control Practices Advisory Committee (HICPAC), 1997. MMWR 1997;46(No. RR-18).

\section{Update: Influenza Activity - United States, March 19-25, 2006}

During March 19-25, 2006, ${ }^{*}$ the number of states reporting widespread influenza activity ${ }^{\dagger}$ decreased to 16 . Sixteen states reported regional activity, 13 reported local activity, and five reported sporadic activity (Figure 1). ${ }^{\S}$

The percentage of specimens testing positive for influenza remained at the same level as recent weeks in the United States. During the preceding 3 weeks (weeks 10-12), the percentage of specimens testing positive for influenza ranged from $30.6 \%$ and $28.6 \%$ in the South Atlantic and East South Central regions, respectively, to $9.7 \%$ in the Pacific region. During this period, $60.3 \%$ of isolates from the Mountain region have been influenza B. Other regions reporting $>30.0 \%$ of recent isolates as influenza B include the East North Central, West North Central, West South Central, and Pacific regions. The percentage of outpatient visits for influenza-like illness (ILI) ${ }^{9}$ during the week ending March 25 remains above the national

\footnotetext{
* Provisional data reported as of March 24. Additional information about influenza activity is updated each Friday and is available from CDC at http://www.cdc.gov/flu. ${ }^{\dagger}$ Levels of activity are 1) widespread: outbreaks of influenza or increases in influenza-like illness (ILI) cases and recent laboratory-confirmed influenza in at least half the regions of a state; 2) regional: outbreaks of influenza or increases in ILI cases and recent laboratory-confirmed influenza in at least two but less than half the regions of a state; 3) local: outbreaks of influenza or increases in ILI cases and recent laboratory-confirmed influenza in a single region of a state; 4) sporadic: small numbers of laboratory-confirmed influenza cases or a single influenza outbreak reported but no increase in cases of ILI; and 5) no activity.

$\$$ Widespread: Arkansas, Connecticut, Delaware, Indiana, Kentucky, Maine, Maryland, Massachusetts, New York, North Dakota, Ohio, Rhode Island, South Carolina, Vermont, Virginia, and West Virginia; regional: Georgia, Hawaii, Illinois, Iowa, Michigan, Minnesota, Montana, Nebraska, New Hampshire, New Jersey, North Carolina, Pennsylvania, South Dakota, Tennessee, Texas, and Wisconsin; local: Alabama, Alaska, California, Colorado, Florida, Idaho, Kansas, Missouri, Nevada, Oklahoma, Oregon, Washington, and Wyoming; sporadic: Arizona, Louisiana, Mississippi, New Mexico, and Utah; no activity: none; no report: none.

Temperature of $>100.0^{\circ} \mathrm{F}\left(>37.8^{\circ} \mathrm{C}\right)$ and cough and/or sore throat in the absence of a known cause other than influenza.
}

FIGURE 1. Estimated influenza activity levels reported by state epidemiologists, by state and level of activity* - United States, March 19-25, 2006

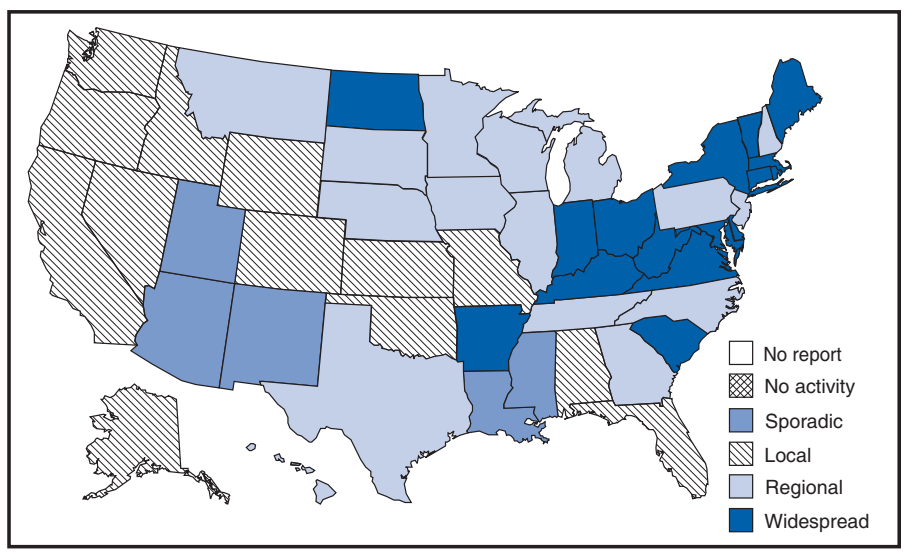

* Levels of activity are 1) widespread: outbreaks of influenza or increases in influenza-like illness (ILI) cases and recent laboratory-confirmed influenza in at least half the regions of a state; 2) regional: outbreaks of influenza or increases in ILI cases and recent laboratory-confirmed influenza in at least two but less than half the regions of a state; 3) local: outbreaks of influenza or increases in ILI cases and recent laboratory-confirmed influenza in a single region of a state; 4) sporadic: small numbers of laboratory-confirmed influenza cases or a single influenza outbreak reported but no increase in cases of ILI; and 5) no activity.

baseline. ${ }^{* *}$ The percentage of deaths attributed to pneumonia and influenza (P\&I) was below the epidemic threshold for the week ending March 25.

\section{Laboratory Surveillance}

During March 19-25, World Health Organization (WHO) collaborating laboratories and National Respiratory and Enteric Virus Surveillance System (NREVSS) laboratories in the United States reported testing 3,158 specimens for influenza viruses, of which 681 (21.6\%) were positive. Of these, 77 were influenza A (H3N2) viruses, 70 were influenza A $(\mathrm{H} 1 \mathrm{~N} 1)$ viruses, 347 were influenza $\mathrm{A}$ viruses that were not subtyped, and 187 were influenza B viruses.

Since October 2, 2005, WHO and NREVSS laboratories have tested 110,066 specimens for influenza viruses, of which $13,532(12.3 \%)$ were positive. Of these, $11,989(88.6 \%)$ were influenza A viruses, and 1,543 (11.4\%) were influenza B viruses. Of the 11,989 influenza A viruses, 4,875 (40.7\%) have been subtyped; 4,629 (95.0\%) were influenza A (H3N2) viruses, and $246(5.0 \%)$ were influenza $\mathrm{A}(\mathrm{H} 1 \mathrm{~N} 1)$ viruses.

\footnotetext{
** The national baseline was calculated as the mean percentage of visits for ILI during noninfluenza weeks for the preceding three seasons, plus two standard deviations. Noninfluenza weeks are those in which $<10 \%$ of laboratory specimens are positive for influenza. Wide variability in regional data precludes calculating region-specific baselines; therefore, applying the national baseline to regional data is inappropriate.
} 


\section{P\&I Mortality and ILI Surveillance}

During the week ending March 25, P\&I accounted for 7.7\% of all deaths reported through the 122 Cities Mortality Reporting System. This percentage is below the epidemic threshold ${ }^{\dagger \dagger}$ of $8.2 \%$ (Figure 2).

The percentage of patient visits for ILI was $2.5 \%$, which is above the national baseline of $2.2 \%$ (Figure 3). The percentage of patient visits for ILI ranged from $1.4 \%$ in the East South Central region to $3.5 \%$ in the West South Central region.

\section{Pediatric Deaths and Hospitalizations}

During October 2, 2005-March 25, 2006, CDC received reports of 19 influenza-associated deaths in U.S. residents aged $<18$ years. Sixteen of the deaths occurred during the current influenza season, and three occurred during the 2004-05 influenza season.

During October 1, 2005-March 18, 2006, the preliminary laboratory-confirmed influenza-associated hospitalization rate reported by the Emerging Infections Program ${ }^{\mathbb{S}}$ for children aged $0-17$ years was 0.79 per 10,000 . For children aged $0-4$ years and 5-17 years, the rate was 1.88 per 10,000 and 0.22 per 10,000, respectively. During October 30, 2005-March 18,2006 , the preliminary laboratory-confirmed influenzaassociated hospitalization rate for children aged $0-4$ years in the New Vaccine Surveillance Network ${ }^{\mathbf{9 9}}$ was 3.0 per 10,000 .

\section{Human Avian Influenza A (H5N1)}

No human avian influenza A (H5N1) virus infection has ever been identified in the United States. From December 2003 through April 4, 2006, a total of 191 laboratory-confirmed human avian influenza $\mathrm{A}(\mathrm{H} 5 \mathrm{~N} 1)$ infections were reported to WHO from Azerbaijan, Cambodia, China, Egypt, Indonesia, Iraq, Thailand, Turkey, and Vietnam.*** Of these, 108 (57\%) were fatal (Table). This represents an increase of one case and one death in Indonesia and four cases and two deaths in Egypt since March 24 and the first human infections with

\footnotetext{
${ }^{\dagger \dagger}$ The expected seasonal baseline proportion of P\&I deaths reported by the 122 Cities Mortality Reporting System is projected using a robust regression procedure in which a periodic regression model is applied to the observed percentage of deaths from P\&I that occurred during the preceding 5 years. The epidemic threshold is 1.645 standard deviations above the seasonal baseline.

$\$ \$$ The Emerging Infections Program Influenza Project conducts surveillance in 60 counties associated with 12 metropolitan areas: San Francisco, California; Denver, Colorado; New Haven, Connecticut; Atlanta, Georgia; Baltimore, Maryland; Minneapolis/St. Paul, Minnesota; Albuquerque, New Mexico; Las Cruces, New Mexico; Albany, New York; Rochester, New York; Portland, Oregon; and Nashville, Tennessee.

99 The New Vaccine Surveillance Network conducts surveillance in Monroe County, New York; Hamilton County, Ohio; and Davidson County, Tennessee.

*** Available at http://www.who.int/csr/disease/avian_influenza/en.
}

FIGURE 2. Percentage of deaths attributed to pneumonia and influenza (P\&I) reported by the 122 Cities Mortality Reporting System, by week and year — United States, 2002-2006

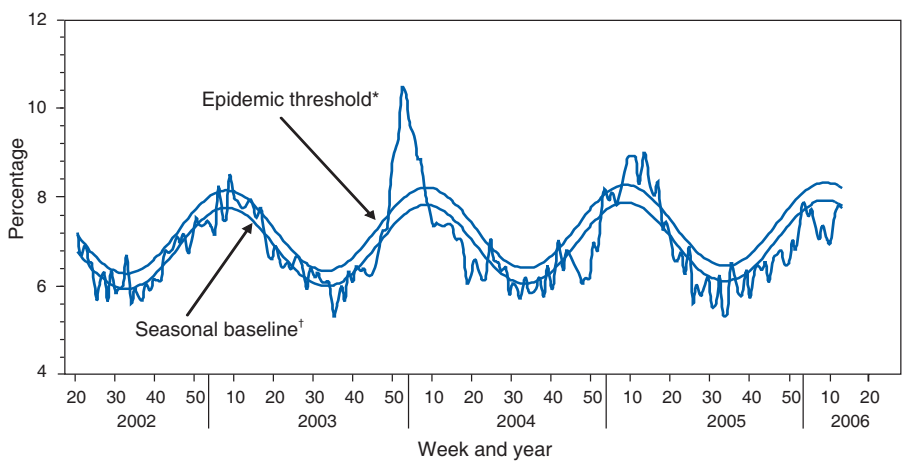

* The epidemic threshold is 1.645 standard deviations above the seasonal baseline.

The seasonal baseline is projected using a robust regression procedure that applies a periodic regression model to the observed percentage of deaths from P\&I during the preceding 5 years.

FIGURE 3. Percentage of visits for influenza-like illness (ILI) reported by the Sentinel Provider Surveillance Network, by week United States, 2003-04, 2004-05, and 2005-06 influenza seasons

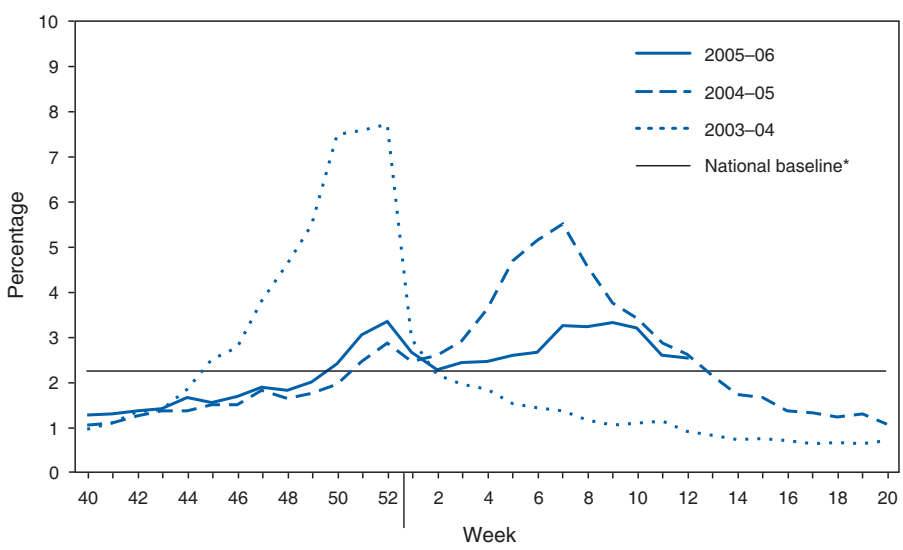

* The national baseline was calculated as the mean percentage of visits for ILI during noninfluenza weeks for the preceding three seasons, plus two standard deviations. Noninfluenza weeks are those in which $<10 \%$ of laboratory specimens are positive for influenza. Wide variability in regional data precludes calculating region-specific baselines; therefore, applying the national baseline to regional data is inappropriate.

avian influenza A (H5N1) reported in Egypt. The majority of infections appear to have been acquired from direct contact with infected poultry. No evidence of sustained human-tohuman transmission of $\mathrm{H} 5 \mathrm{~N} 1$ has been detected, although rare instances of human-to-human transmission likely have occurred (1).

\section{Reference}

1. Ungchusak K, Auewarakul P, Dowell SF, et al. Probable person-to-person transmission of avian influenza A (H5N1). N Engl J Med 2005;352:333-40. 
TABLE. Number of laboratory-confirmed human cases and deaths from avian influenza A (H5N1) infection reported to the World Health Organization, by country - worldwide, 2003-2006*

\begin{tabular}{|c|c|c|c|c|c|c|c|c|c|c|}
\hline \multirow[b]{3}{*}{ Country } & \multicolumn{10}{|c|}{ Year of onset } \\
\hline & \multicolumn{2}{|c|}{2003} & \multicolumn{2}{|c|}{2004} & \multicolumn{2}{|c|}{2005} & \multicolumn{2}{|c|}{2006} & \multicolumn{2}{|c|}{ Total } \\
\hline & $\begin{array}{l}\text { No. of } \\
\text { cases }\end{array}$ & Deaths & $\begin{array}{l}\text { No. of } \\
\text { cases }\end{array}$ & Deaths & $\begin{array}{l}\text { No. of } \\
\text { cases }\end{array}$ & Deaths & $\begin{array}{l}\text { No. of } \\
\text { cases }\end{array}$ & Deaths & $\begin{array}{l}\text { No. of } \\
\text { cases }\end{array}$ & Deaths \\
\hline Azerbaijan & 0 & 0 & 0 & 0 & 0 & 0 & 7 & 5 & 7 & 5 \\
\hline Cambodia & 0 & 0 & 0 & 0 & 4 & 4 & 1 & 1 & 5 & 5 \\
\hline China & 0 & 0 & 0 & 0 & 8 & 5 & 8 & 6 & 16 & 11 \\
\hline Egypt & 0 & 0 & 0 & 0 & 0 & 0 & 4 & 2 & 4 & 2 \\
\hline Indonesia & 0 & 0 & 0 & 0 & 17 & 11 & 13 & 12 & 30 & 23 \\
\hline Iraq & 0 & 0 & 0 & 0 & 0 & 0 & 2 & 2 & 2 & 2 \\
\hline Thailand & 0 & 0 & 17 & 12 & 5 & 2 & 0 & 0 & 22 & 14 \\
\hline Turkey & 0 & 0 & 0 & 0 & 0 & 0 & 12 & 4 & 12 & 4 \\
\hline Viet Nam & 3 & 3 & 29 & 20 & 61 & 19 & 0 & 0 & 93 & 42 \\
\hline Total & 3 & 3 & 46 & 32 & 95 & 41 & 47 & 32 & 191 & 108 \\
\hline
\end{tabular}

${ }^{*}$ As of April 4, 2006.

\section{Notice to Readers}

\section{Discontinuation of Spectinomycin}

In January 2006, CDC learned that Pfizer, Inc. (New York, New York) had discontinued U.S. distribution of spectinomycin (Trobicin ${ }^{\circledR}$ ) in November 2005; remaining inventory will expire in May 2006. No other pharmaceutical company manufactures or sells spectinomycin in the United States. Pfizer is continuing to distribute spectinomycin outside the United States for the international market. CDC and the Food and Drug Administration are working with Pfizer to make spectinomycin available again in the United States and will update this information as soon as possible.

Historically, spectinomycin has been used to treat persons infected with Neisseria gonorrhoeae who cannot receive one of the two first-line treatments (i.e., fluoroquinolones or thirdgeneration cephalosporins) currently recommended for treatment of uncomplicated gonococcal infection (1). Relatively few indications exist for which spectinomycin is the preferred treatment option for $N$. gonorrhoeae; these include 1) pregnant women with penicillin or cephalosporin allergy (fluoroquinolones are contraindicated during pregnancy), 2) persons with penicillin or cephalosporin allergies who reside in areas with a high prevalence of quinolone-resistant $N$. gonorrhoeae $(1,2)$, and 3 ) men with penicillin or cephalosporin allergies who have sex with men (3). No acceptable alternatives to spectinomycin therapy are currently available. Persons with penicillin or cephalosporin allergies who cannot receive fluoroquinolones can be desensitized to cephalosporins before treatment (4). Although 2 grams of azithromycin orally in a single dose is effective against uncomplicated gonococcal infection, no data are available to assess the safety and efficacy of this regimen in pregnant women. Moreover, concerns exist regarding the emergence of antimicrobial resistance if azithromycin is used widely in the treatment of $N$. gonorrhoeae.

\section{References}

1. CDC. Sexually transmitted diseases treatment guidelines 2002. MMWR 2002;51(No. RR-6).
2. CDC. Increases in fluoroquinolone-resistant Neisseria gonorrhoeaeHawaii and California, 2001. MMWR 2002;51:1041-4.

3. CDC. Increases in fluoroquinolone-resistant Neisseria gonorrhoede among men who have sex with men-United States, 2003, and revised recommendations for gonorrhea treatment, 2004. MMWR 2004;53:335-8.

4. Park Miguel A, Li JTC. Diagnosis and management of penicillin allergy. Mayo Clin Proc 2005;80:405-10.

\section{Notice to Readers}

\section{National Child Abuse Prevention Month - April 2006}

April is National Child Abuse Prevention Month (NCAPM). This year's theme is Safe Children and Healthy Families are a Shared Responsibility. Communities throughout the United States will be holding blue ribbon campaigns to promote healthy families, organizing educational fairs, and honoring parenting heroes.

Many cases of child maltreatment go unreported to authorities. However, approximately 906,000 children in the United States were confirmed by child protective services as being abused or neglected in 2003, a rate of 12.4 per 1,000 children (1). Of the reported cases, $5 \%$ involved emotional or psychological abuse, $10 \%$ involved sexual abuse, $9 \%$ involved physical abuse, and 61\% involved neglect (1).

Persistent stress resulting from child maltreatment can disrupt early brain development and impair development of the nervous and immune response systems (2). Children who experience maltreatment are at increased risk for adverse health effects throughout their lives (e.g., suicide, obesity, smoking, alcoholism, drug abuse, depression, eating disorders, sexual promiscuity, and certain chronic diseases) $(3,4)$. In addition, persons who are abused as children are twice as likely to be assaulted as adults (5).

NCAPM is an opportunity to raise awareness about child maltreatment and its devastating effects. Information about child maltreatment is available online from CDC at 
http://www.cdc.gov/injury. NCAPM materials are available online from the U.S. Department of Health and Human Services, Administration for Children and Families, at http://nccanch.acf.hhs.gov.

\section{References}

1. US Department of Health and Human Services, Administration for Children and Families. Child maltreatment 2003. Washington, DC: Government Printing Office; 2005. Available at http://www.acf.hhs.gov/ programs/cb/pubs/cm03/index.htm.

2. National Scientific Council on the Developing Child. Excessive stress disrupts the architecture of the developing brain. Working paper no. 3. Waltham, MA: National Scientific Council on the Developing Child; 2005. Available at http://www.developingchild.net/reports.shtml.

3. Felitti V, Anda R, Nordenberg D, et al. Relationship of childhood abuse and household dysfunction to many of the leading causes of death in adults. Am J Prev Med 1998;14:245-58.

4. Runyan D, Wattam C, Ikeda R, Hassan F, Ramiro L. Child abuse and neglect by parents and caregivers. In: Krug E, Dahlberg LL, Mercy JA, Zwi AB, Lozano R, eds. World report on violence and health. Geneva, Switzerland: World Health Organization; 2002:59-86.

5. Tjaden P, Thoennes N. Full report of the prevalence, incidence, and consequences of violence against women: findings from the National Violence Against Women Survey. Washington, DC: National Institute of Justice; 2000. Report no. NCJ 183781.

\section{Notice to Readers}

\section{Sexual Assault Awareness Month - April 2006}

April is Sexual Assault Awareness Month (SAAM). Throughout the month, CDC encourages communities to promote healthy relationships and to increase awareness about the devastating impact of sexual violence.

Sexual violence affects persons at all stages of life. In 2003, approximately two out of 1,000 children in the United States were confirmed by child protective services as having been sexually assaulted (1). Many sexually abused children, however, are not identified by child protective services. In 2003, approximately $9 \%$ of high school students reported having been forced to have sexual intercourse (2). At least one in six women and one in 33 men in the United States have been victims of rape or attempted rape in their lifetime (3).

The consequences of sexual violence can be severe. Survivors can suffer short-term physical injuries, including genital tearing, bruises, and broken bones (4). Long-term health consequences can include sexually transmitted diseases, irritable bowel syndrome, gastrointestinal problems, and chronic neck, back, and facial pain (5). In addition, survivors often face serious mental health problems, including post-traumatic stress disorder (4). Many survivors do not tell friends and family about the assault and consequently suffer the physical and psychological consequences alone (4). Those who do disclose their abuse might be stigmatized by their family, friends, and communities.
Communities are encouraged to plan activities in recognition of SAAM. A calendar of national, state, and local events is available at http://www.nsvrc.org. Information about sexual violence is available at http://www.cdc.gov/injury. SAAM materials are available from the National Sexual Violence Resource Center, 123 North Enola Drive, Enola, PA 17025; telephone 877-739-3895 and at http://www.nsvrc.org.

\section{References}

1. US Department of Health and Human Services, Administration on Children, Youth, and Families. Child maltreatment 2003. Washington, DC: Government Printing Office; 2005. Available at http://www. acf.hhs.gov/programs/cb/pubs/cm03/index.htm.

2. CDC. Youth Risk Behavior Surveillance-United States, 2003. MMWR 2004; 53(No. SS-2).

3. Tjaden P, Thoennes N. Full report of the prevalence, incidence, and consequences of violence against women: findings from the National Violence Against Women Survey. Washington, DC: National Institute of Justice; 2000. Report no. NCJ 183781.

4. Basile K. Sexual violence in the lives of girls and women. In: KendallTackett K, ed. Handbook of women, stress, and trauma. New York, NY: Brunner-Routledge; 2005:101-22.

5. Jewkes R, Sen P, Garcia-Moreno C. Sexual violence. In: Krug E, Dahlberg LL, Mercy JA, et al., eds. World report on violence and health. Geneva, Switzerland: World Health Organization; 2002:213-39.

\section{Notice to Readers}

\section{Autism Awareness Month - April 2006}

Autism spectrum disorders (ASDs) are lifelong developmental disabilities characterized by unusual social and communication development and the presence of unusual or repetitive behaviors and interests (1). These conditions affect an estimated 2-6 per 1,000 children (2), making autism a serious public health concern. Early identification and intervention can help children progress in their development and show improvements in their language, cognitive, social, motor, and other developmental skills (3).

April is Autism Awareness Month. In collaboration with partners, $\mathrm{CDC}$ is conducting a public awareness campaign to educate health-care and child-care providers regarding potential early warning signs of autism and other developmental disabilities. Additional information about autism and the CDC campaign are available at http://www.cdc.gov/autism and http://www.cdc.gov/actearly.

\section{References}

1. American Psychiatric Association. Criteria for the pervasive developmental disorders. Diagnostic and statistical manual of mental disorders, fourth edition, text revision. Washington, DC: American Psychiatric Association; 2000.

2. CDC. How common are Autism Spectrum Disorders (ASDs)? Atlanta, GA: CDC, National Center on Birth Defects and Developmental Disabilities; 2005. Available at http://www.cdc.gov/ncbddd/autism/ asd_common.htm.

3. National Research Council's Committee on Educational Interventions for Children with Autism. Educating children with autism. Washington, DC: National Academies Press; 2001. 


\section{Notice to Readers}

\section{Introduction of New Table IV Postponed}

Because of technical problems, introduction of the new quarterly Table IV with data from the National Notifiable Diseases Surveillance System has been postponed. Table IV presents quarterly data on cases of human immunodeficiency virus (HIV)/acquired immunodeficiency syndrome (AIDS), AIDS, and tuberculosis.

\section{QuickStats}

FROM THE NATIONAL CENTER FOR HEALTH STATISTICS

\section{Percentage of Hospital Emergency Departments (EDs) Having to Divert Ambulances, by Selected Characteristics - United States, 2003}

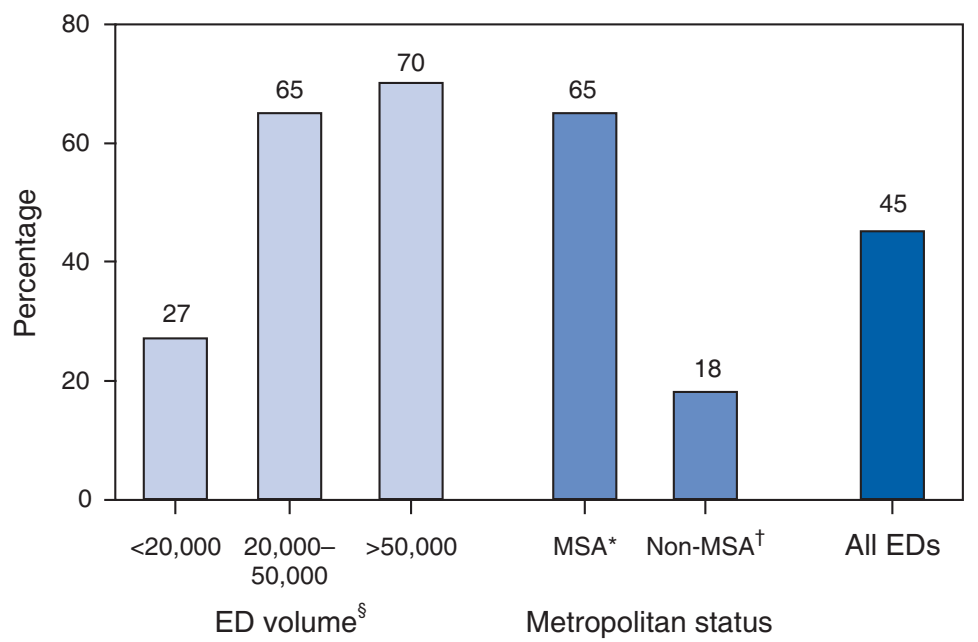

${ }^{*}$ MSA $=$ Metropolitan Statistical Area, defined by the U.S. Census Bureau.

$\dagger$ Estimate does not meet standard of reliability or precision because the relative standard error is $>30 \%$.

$\S$ Number of visits annually.

Ambulance diversion occurs when EDs are too crowded to handle any more critically ill or injured patients and request that ambulances bypass them for another hospital. In 2003 , an estimated $45 \%$ of hospital EDs were on diversion status at some time during the previous year. Ambulance diversions were more common in EDs with larger volumes of patients and those in metropolitan areas.

SOURCES: 2003 National Hospital Ambulatory Medical Care Survey. Available at http://www.cdc.gov/ nchs/about/major/ahcd/ahcd1.htm; Burt C, McCaig L, Valverde R. Analysis of ambulance transports and diversions among US emergency departments. Ann Emerg Med 2006;47:317-26. 
TABLE I. Provisional cases of infrequently reported notifiable diseases ( $<1,000$ cases reported during the preceding year) - United States, week ending April 1, 2006 (13th Week)*

\begin{tabular}{|c|c|c|c|c|c|c|c|c|c|}
\hline \multirow[b]{2}{*}{ Disease } & \multirow{2}{*}{$\begin{array}{l}\text { Current } \\
\text { week }\end{array}$} & \multirow{2}{*}{$\begin{array}{l}\text { Cum } \\
2006\end{array}$} & \multirow{2}{*}{$\begin{array}{c}\text { 5-year } \\
\text { weekly } \\
\text { average }^{\dagger}\end{array}$} & \multicolumn{5}{|c|}{ Total cases reported for previous years } & \multirow[b]{2}{*}{ States reporting cases during current week (No.) } \\
\hline & & & & 2005 & 2004 & 2003 & 2002 & 2001 & \\
\hline Anthrax & - & 1 & - & - & - & - & 2 & 23 & \\
\hline \multicolumn{10}{|l|}{ Botulism: } \\
\hline foodborne & - & - & 0 & 18 & 16 & 20 & 28 & 39 & \\
\hline infant & 1 & 16 & 1 & 90 & 87 & 76 & 69 & 97 & NY (1) \\
\hline other (wound \& unspecified) & 1 & 11 & 0 & 25 & 30 & 33 & 21 & 19 & CA (1) \\
\hline Brucellosis & - & 18 & 2 & 121 & 114 & 104 & 125 & 136 & \\
\hline Chancroid & 3 & 9 & 1 & 27 & 30 & 54 & 67 & 38 & $\mathrm{SC}(3)$ \\
\hline Cholera & - & - & 0 & 6 & 5 & 2 & 2 & 3 & \\
\hline Cyclosporiasis $\S$ & - & 11 & 2 & 737 & 171 & $7 \overline{5}$ & 156 & 147 & \\
\hline Diphtheria & - & - & - & - & - & 1 & 1 & 2 & \\
\hline \multicolumn{10}{|l|}{ Domestic arboviral diseases ${ }^{\S \uparrow}$} \\
\hline California serogroup & - & - & 0 & 77 & 112 & 108 & 164 & 128 & \\
\hline eastern equine & - & - & - & 21 & 6 & 14 & 10 & 9 & \\
\hline Powassan & - & - & - & 1 & 1 & - & 1 & $\mathrm{~N}$ & \\
\hline St. Louis & - & - & 0 & 10 & 12 & 41 & 28 & 79 & \\
\hline western equine & - & - & - & - & - & - & - & - & \\
\hline \multicolumn{10}{|l|}{ Ehrlichiosis§: } \\
\hline human granulocytic & - & 8 & 2 & 735 & 537 & 362 & 511 & 261 & \\
\hline human monocytic & 2 & 40 & 1 & 456 & 338 & 321 & 216 & 142 & $\mathrm{MD}(1), \mathrm{NC}(1)$ \\
\hline \multirow{2}{*}{\multicolumn{10}{|c|}{ Haemophilus influenzae, }} \\
\hline & & & & & & & & & \\
\hline $\begin{array}{l}\text { invasive disease (age }<5 \text { yrs): } \\
\text { serotype b }\end{array}$ & - & 2 & 0 & 8 & 19 & 32 & 34 & - & \\
\hline nonserotype b & 2 & 22 & 3 & 118 & 135 & 117 & $\begin{array}{r}34 \\
144\end{array}$ & - & $\mathrm{FL}(2)$ \\
\hline unknown serotype & 4 & 53 & 4 & 217 & 177 & 227 & 153 & - & $\mathrm{OH}(1), \mathrm{VA}(1), \mathrm{GA}(1), \mathrm{UT}(1)$ \\
\hline Hansen disease ${ }^{\S}$ & - & 10 & 2 & 85 & 105 & 95 & 96 & 79 & \\
\hline Hantavirus pulmonary syndrome $e^{\S}$ & 1 & 4 & 0 & 22 & 24 & 26 & 19 & 8 & $\mathrm{TX}(1)$ \\
\hline Hemolytic uremic syndrome, postdiarrheal $\$$ & 1 & 13 & 2 & 205 & 200 & 178 & 216 & 202 & $\mathrm{CO}(1)$ \\
\hline Hepatitis C viral, acute & 5 & 182 & 35 & 784 & 713 & 1,102 & 1,835 & 3,976 & NY (1), MI (1), MO (1), TX (1), CA (1) \\
\hline HIV infection, pediatric (age $<13 \mathrm{yrs})^{\S \dagger \dagger}$ & - & - & 5 & 382 & 436 & 504 & 420 & 543 & \\
\hline Influenza-associated pediatric mortality,§, গा & 1 & 13 & 1 & 51 & - & $\mathrm{N}$ & $\mathrm{N}$ & $\mathrm{N}$ & $\mathrm{RI}(1)$ \\
\hline Listeriosis & 6 & 110 & 9 & 870 & 753 & 696 & 665 & 613 & $\mathrm{OH}(2), \mathrm{IN}(2), \mathrm{NE}(1), \mathrm{AL}(1)$ \\
\hline Measles & - & $4^{\star * *}$ & 2 & 64 & 37 & 56 & 44 & 116 & \\
\hline \multicolumn{10}{|l|}{ Meningococcal disease, ${ }^{\mathrm{tt \dagger}}$ invasive: } \\
\hline$A, C, Y, \& W-135$ & 4 & 65 & 6 & 301 & - & - & - & - & $\mathrm{OH}(1), \mathrm{IN}(2), \mathrm{FL}(1)$ \\
\hline serogroup $B$ & 6 & 41 & 3 & 178 & - & - & - & - & $\mathrm{NY}(1), \mathrm{OH}(1), \mathrm{IN}(2), \mathrm{TX}(1), \mathrm{WA}(1)$ \\
\hline other serogroup & 1 & 6 & 1 & 25 & - & - & - & - & $\mathrm{OH}(1)$ \\
\hline Mumps & 11 & 246 & 5 & 298 & 258 & 231 & 270 & 266 & IA (3), KS (4), FL (1), WA (2), CA (1) \\
\hline Plague & - & 1 & - & 7 & 3 & 1 & 2 & 2 & \\
\hline Poliomyelitis, paralytic & - & - & - & 1 & - & - & - & - & \\
\hline Psittacosis $§$ & - & 1 & 0 & 23 & 12 & 12 & 18 & 25 & \\
\hline$Q$ fever ${ }^{\S}$ & 2 & 28 & 1 & 125 & 70 & 71 & 61 & 26 & $\mathrm{FL}(1), \mathrm{CA}(1)$ \\
\hline Rabies, human & - & - & 0 & 2 & 7 & 2 & 3 & 1 & \\
\hline Rubella & - & 1 & 0 & 10 & 10 & 7 & 18 & 23 & \\
\hline Rubella, congenital syndrome & - & - & 0 & 1 & - & 1 & 1 & 3 & \\
\hline SARS-CoV§§§ & - & - & 0 & - & - & 8 & $\mathrm{~N}$ & $\mathrm{~N}$ & \\
\hline Smallpox $\S$ & - & - & - & - & - & - & - & - & \\
\hline Streptococcal toxic-shock syndrome $§$ & 2 & 36 & 4 & 104 & 132 & 161 & 118 & 77 & $\mathrm{OH}(2)$ \\
\hline \multicolumn{10}{|l|}{ Streptococcus pneumoniae,,} \\
\hline invasive disease (age < 5 yrs) & 16 & 267 & 16 & 1,107 & 1,162 & 845 & 513 & 498 & MA (1), NY (6), PA (2), OH (2), IN (3), CO (1), AZ (1) \\
\hline Syphilis, congenital (age $<1$ yr) & - & 46 & 8 & 342 & 353 & 413 & 412 & 441 & \\
\hline Tetanus & - & 3 & 0 & 20 & 34 & 20 & 25 & 37 & \\
\hline Toxic-shock syndrome (other than streptococcal) ${ }^{\S}$ & l) $)^{\S} 6$ & 32 & 2 & 92 & 95 & 133 & 109 & 127 & $\mathrm{OH}(2), \mathrm{MI}(1), \mathrm{CA}(3)$ \\
\hline Trichinellosis & - & 2 & 0 & 21 & 5 & 6 & 14 & 22 & \\
\hline Tularemia ${ }^{\S}$ & - & 3 & 0 & 137 & 134 & 129 & 90 & 129 & \\
\hline Typhoid fever & 3 & 49 & 5 & 305 & 322 & 356 & 321 & 368 & CA (3) \\
\hline Vancomycin-intermediate Staphylococcus aureus & $u s^{\S}-$ & - & - & 2 & - & $\mathrm{N}$ & $\mathrm{N}$ & $\mathrm{N}$ & \\
\hline Vancomycin-resistant Staphylococcus aureus ${ }^{\S}$ & - & - & - & - & 1 & $\mathrm{~N}$ & $\mathrm{~N}$ & $\mathrm{~N}$ & \\
\hline Yellow fever & - & - & - & - & - & - & 1 & - & \\
\hline
\end{tabular}

-: No reported cases. N: Not notifiable. Cum: Cumulative year-to-date counts.

* Incidence data for reporting years 2004, 2005, and 2006 are provisional, whereas data for 2001, 2002, and 2003 are finalized.

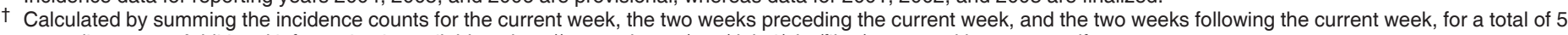
preceding years. Additional information is available at http://www.cdc.gov/epo/dphsi/phs/files/5yearweeklyaverage.pdf.

$\S$ Not notifiable in all states.

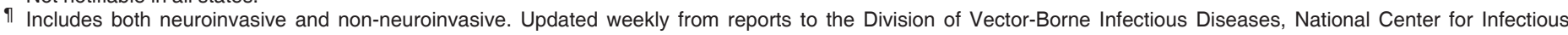
Diseases (ArboNET Surveillance).

** Data for $H$. influenzae (all ages, all serotypes) are available in Table II.

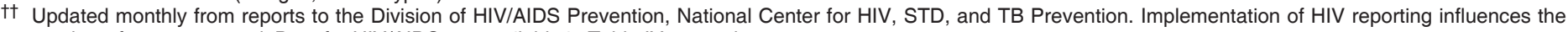
number of cases reported. Data for HIV/AIDS are available in Table IV quarterly.

$\S \S$ Updated weekly from reports to the Division of Viral and Rickettsial Diseases, National Center for Infectious Diseases.

१ๆ Of the 20 cases reported since October 2, 2005 (week 40), only 17 occurred during the current 2005-06 season.

*** No measles cases were reported for the current week.

t†† Data for meningococcal disease (all serogroups and unknown serogroups) are available in Table II. 
TABLE II. Provisional cases of selected notifiable diseases, United States, weeks ending April 1, 2006, and April 2, 2005 (13th Week)*

\begin{tabular}{|c|c|c|c|c|c|c|c|c|c|c|c|c|c|c|c|}
\hline \multirow[b]{3}{*}{ Reporting area } & \multicolumn{5}{|c|}{ Chlamydia $^{\dagger}$} & \multicolumn{5}{|c|}{ Coccidioidomycosis } & \multicolumn{5}{|c|}{ Cryptosporidiosis } \\
\hline & \multirow{2}{*}{$\begin{array}{c}\text { Current } \\
\text { week }\end{array}$} & \multicolumn{2}{|c|}{$\begin{array}{l}\text { Previous } \\
52 \text { weeks }\end{array}$} & \multirow{2}{*}{$\begin{array}{l}\text { Cum } \\
2006 \\
\end{array}$} & \multirow{2}{*}{$\begin{array}{l}\text { Cum } \\
2005\end{array}$} & \multirow{2}{*}{$\begin{array}{c}\text { Current } \\
\text { week }\end{array}$} & \multicolumn{2}{|c|}{$\begin{array}{l}\text { Previous } \\
52 \text { weeks }\end{array}$} & \multirow{2}{*}{$\begin{array}{l}\text { Cum } \\
2006\end{array}$} & \multirow{2}{*}{$\begin{array}{l}\text { Cum } \\
2005\end{array}$} & \multirow{2}{*}{$\begin{array}{c}\text { Current } \\
\text { week }\end{array}$} & \multicolumn{2}{|c|}{$\begin{array}{l}\text { Previous } \\
52 \text { weeks }\end{array}$} & \multirow{2}{*}{$\begin{array}{l}\text { Cum } \\
2006\end{array}$} & \multirow{2}{*}{$\begin{array}{l}\text { Cum } \\
2005 \\
\end{array}$} \\
\hline & & Med & Max & & & & Med & Max & & & & Med & $\operatorname{Max}$ & & \\
\hline United States & 12,484 & 18,452 & 25,241 & 204,070 & 236,883 & 195 & 107 & 1,203 & 2,221 & 1,059 & 27 & 70 & 852 & 532 & 448 \\
\hline $\begin{array}{l}\text { New England } \\
\text { Connecticut } \\
\text { Maine } \\
\text { Massachusetts } \\
\text { New Hampshire } \\
\text { Rhode Island } \\
\text { Vermont } \$\end{array}$ & $\begin{array}{r}467 \\
- \\
358 \\
19 \\
74 \\
16\end{array}$ & $\begin{array}{r}616 \\
156 \\
41 \\
277 \\
34 \\
64 \\
19\end{array}$ & $\begin{array}{r}1,536 \\
1,199 \\
74 \\
441 \\
64 \\
99 \\
43\end{array}$ & $\begin{array}{r}6,646 \\
913 \\
465 \\
3,708 \\
415 \\
828 \\
317\end{array}$ & $\begin{array}{r}6,643 \\
928 \\
562 \\
3,574 \\
474 \\
845 \\
260\end{array}$ & $\begin{array}{l}-\bar{N} \\
N \\
- \\
- \\
N\end{array}$ & $\begin{array}{l}0 \\
0 \\
0 \\
0 \\
0 \\
0 \\
0\end{array}$ & $\begin{array}{l}0 \\
0 \\
0 \\
0 \\
0 \\
0 \\
0\end{array}$ & $\begin{array}{l}\bar{N} \\
\mathrm{~N} \\
- \\
\mathrm{N}\end{array}$ & $\begin{array}{l}\bar{N} \\
\mathrm{~N} \\
- \\
- \\
\mathrm{N}\end{array}$ & $\begin{array}{l}- \\
- \\
- \\
-\end{array}$ & $\begin{array}{l}4 \\
0 \\
0 \\
2 \\
0 \\
0 \\
0\end{array}$ & $\begin{array}{r}34 \\
14 \\
3 \\
15 \\
3 \\
6 \\
5\end{array}$ & $\begin{array}{r}32 \\
4 \\
6 \\
15 \\
5 \\
-2\end{array}$ & $\begin{array}{r}24 \\
3 \\
3 \\
7 \\
4 \\
1 \\
6\end{array}$ \\
\hline $\begin{array}{l}\text { Mid. Atlantic } \\
\text { New Jersey } \\
\text { New York (Upstate) } \\
\text { New York City } \\
\text { Pennsylvania }\end{array}$ & $\begin{array}{r}1,771 \\
150 \\
521 \\
474 \\
626\end{array}$ & $\begin{array}{r}2,202 \\
356 \\
499 \\
631 \\
714\end{array}$ & $\begin{array}{r}3,702 \\
527 \\
1,715 \\
1,167 \\
1,084\end{array}$ & $\begin{array}{r}19,482 \\
3,016 \\
4,999 \\
2,308 \\
9,159\end{array}$ & $\begin{array}{r}28,353 \\
4,501 \\
4,907 \\
9,617 \\
9,328\end{array}$ & $\begin{array}{l}-\bar{N} \\
N \\
N \\
N\end{array}$ & $\begin{array}{l}0 \\
0 \\
0 \\
0 \\
0\end{array}$ & $\begin{array}{l}0 \\
0 \\
0 \\
0 \\
0\end{array}$ & $\begin{array}{l}- \\
N \\
N \\
N \\
N\end{array}$ & $\begin{array}{l}- \\
N \\
N \\
N \\
N\end{array}$ & $\begin{array}{l}\frac{5}{5} \\
- \\
-\end{array}$ & $\begin{array}{r}10 \\
0 \\
3 \\
2 \\
4\end{array}$ & $\begin{array}{r}598 \\
8 \\
562 \\
15 \\
21\end{array}$ & $\begin{array}{r}77 \\
22 \\
7 \\
48\end{array}$ & $\begin{array}{r}69 \\
5 \\
16 \\
22 \\
26\end{array}$ \\
\hline $\begin{array}{l}\text { E.N. Central } \\
\text { Illinois } \\
\text { Indiana } \\
\text { Michigan } \\
\text { Ohio } \\
\text { Wisconsin }\end{array}$ & $\begin{array}{r}2,136 \\
422 \\
319 \\
1,206 \\
97 \\
92\end{array}$ & $\begin{array}{r}3,193 \\
959 \\
393 \\
577 \\
812 \\
396\end{array}$ & $\begin{array}{r}4,146 \\
1,784 \\
558 \\
1,928 \\
1,445 \\
531\end{array}$ & $\begin{array}{r}40,777 \\
10,077 \\
5,061 \\
12,369 \\
8,464 \\
4,806\end{array}$ & $\begin{array}{r}38,332 \\
9,612 \\
5,117 \\
6,153 \\
12,284 \\
5,166\end{array}$ & $\begin{array}{l}- \\
\frac{\mathrm{N}}{\mathrm{N}} \\
\overline{\mathrm{N}}\end{array}$ & $\begin{array}{l}0 \\
0 \\
0 \\
0 \\
0 \\
0\end{array}$ & $\begin{array}{l}3 \\
0 \\
0 \\
3 \\
1 \\
0\end{array}$ & $\begin{array}{r}9 \\
\mathrm{~N} \\
5 \\
4 \\
\mathrm{~N}\end{array}$ & $\begin{array}{l}\frac{2}{\mathrm{~N}} \\
\frac{2}{\mathrm{~N}}\end{array}$ & $\begin{array}{l}13 \\
3 \\
3 \\
7 \\
-\end{array}$ & $\begin{array}{r}13 \\
1 \\
1 \\
2 \\
5 \\
4\end{array}$ & $\begin{array}{r}162 \\
16 \\
13 \\
7 \\
109 \\
38\end{array}$ & $\begin{array}{r}116 \\
8 \\
9 \\
23 \\
56 \\
20\end{array}$ & $\begin{array}{r}86 \\
13 \\
5 \\
12 \\
26 \\
30\end{array}$ \\
\hline $\begin{array}{l}\text { W.N. Central } \\
\text { lowa } \\
\text { Kansas } \\
\text { Minnesota } \\
\text { Missouri } \\
\text { Nebraska } \\
\text { North Dakota } \\
\text { South Dakota }\end{array}$ & $\begin{array}{r}766 \\
105 \\
216 \\
1 \\
208 \\
175 \\
-61\end{array}$ & $\begin{array}{r}1,119 \\
143 \\
151 \\
228 \\
435 \\
97 \\
32 \\
52\end{array}$ & $\begin{array}{r}1,449 \\
225 \\
269 \\
294 \\
525 \\
150 \\
50 \\
118\end{array}$ & $\begin{array}{r}13,649 \\
2,059 \\
2,102 \\
2,128 \\
5,049 \\
1,290 \\
362 \\
659\end{array}$ & $\begin{array}{r}14,883 \\
1,764 \\
1,882 \\
3,221 \\
5,675 \\
1,311 \\
337 \\
693\end{array}$ & $\begin{array}{l}- \\
N \\
N \\
- \\
N \\
N \\
N\end{array}$ & $\begin{array}{l}0 \\
0 \\
0 \\
0 \\
0 \\
0 \\
0 \\
0\end{array}$ & $\begin{array}{l}1 \\
0 \\
0 \\
0 \\
1 \\
1 \\
0 \\
0\end{array}$ & $\begin{array}{l}\bar{N} \\
N \\
- \\
N \\
N \\
N\end{array}$ & $\begin{array}{l}3 \\
N \\
N \\
3 \\
N \\
N \\
N\end{array}$ & $\begin{array}{l}- \\
- \\
- \\
- \\
-\end{array}$ & $\begin{array}{l}9 \\
1 \\
0 \\
2 \\
2 \\
0 \\
0 \\
0\end{array}$ & $\begin{array}{r}51 \\
11 \\
5 \\
10 \\
37 \\
2 \\
1 \\
4\end{array}$ & $\begin{array}{r}69 \\
5 \\
13 \\
30 \\
15 \\
3 \\
3\end{array}$ & $\begin{array}{r}61 \\
13 \\
7 \\
15 \\
24 \\
- \\
2\end{array}$ \\
\hline $\begin{array}{l}\text { S. Atlantic } \\
\text { Delaware } \\
\text { District of Columbia } \\
\text { Florida } \\
\text { Georgia } \\
\text { Maryland } \\
\text { North Carolina } \\
\text { South Carolina } \\
\text { Virginia§ } \\
\text { West Virginia }\end{array}$ & $\begin{array}{r}3,429 \\
84 \\
32 \\
674 \\
14 \\
195 \\
555 \\
1,306 \\
480 \\
89\end{array}$ & $\begin{array}{r}3,246 \\
69 \\
64 \\
868 \\
585 \\
364 \\
548 \\
312 \\
425 \\
48\end{array}$ & $\begin{array}{r}4,928 \\
92 \\
103 \\
1,032 \\
2,057 \\
525 \\
1,743 \\
1,418 \\
841 \\
353\end{array}$ & $\begin{array}{r}39,858 \\
948 \\
478 \\
11,254 \\
3,670 \\
4,367 \\
8,789 \\
4,013 \\
5,226 \\
1,113\end{array}$ & $\begin{array}{r}45,664 \\
777 \\
995 \\
11,024 \\
7,377 \\
4,371 \\
8,718 \\
5,673 \\
6,175 \\
554\end{array}$ & $\begin{array}{l}\bar{N} \\
\frac{N}{N} \\
\frac{N}{N} \\
\frac{N}{N}\end{array}$ & $\begin{array}{l}0 \\
0 \\
0 \\
0 \\
0 \\
0 \\
0 \\
0 \\
0 \\
0\end{array}$ & $\begin{array}{l}1 \\
0 \\
0 \\
0 \\
0 \\
1 \\
0 \\
0 \\
0 \\
0\end{array}$ & $\begin{array}{l}2 \\
\frac{\mathrm{N}}{\mathrm{N}} \\
\frac{\mathrm{N}}{2} \\
\mathrm{~N} \\
\mathrm{~N} \\
\mathrm{~N}\end{array}$ & $\begin{array}{l}\bar{N} \\
\frac{N}{-} \\
\frac{N}{N} \\
N\end{array}$ & $\begin{array}{l}6 \\
-\overline{6} \\
- \\
- \\
- \\
-\end{array}$ & $\begin{array}{r}14 \\
0 \\
0 \\
6 \\
3 \\
0 \\
1 \\
0 \\
1 \\
0\end{array}$ & $\begin{array}{r}53 \\
2 \\
3 \\
28 \\
12 \\
4 \\
10 \\
4 \\
8 \\
3\end{array}$ & $\begin{array}{r}164 \\
5 \\
62 \\
54 \\
7 \\
23 \\
3 \\
9 \\
1\end{array}$ & $\begin{array}{r}87 \\
1 \\
28 \\
25 \\
4 \\
12 \\
4 \\
9 \\
4\end{array}$ \\
\hline $\begin{array}{l}\text { E.S. Central } \\
\text { Alabama } \\
\text { Kentucky } \\
\text { Mississippi } \\
\text { Tennessee }^{\S}\end{array}$ & $\begin{array}{r}1,184 \\
398 \\
280 \\
- \\
506\end{array}$ & $\begin{array}{r}1,374 \\
351 \\
150 \\
381 \\
457\end{array}$ & $\begin{array}{r}2,188 \\
1,048 \\
323 \\
801 \\
624\end{array}$ & $\begin{array}{r}17,153 \\
4,925 \\
2,343 \\
3,524 \\
6,361\end{array}$ & $\begin{array}{r}17,022 \\
2,446 \\
3,087 \\
5,731 \\
5,758\end{array}$ & $\begin{array}{l}\bar{N} \\
\frac{N}{N}\end{array}$ & $\begin{array}{l}0 \\
0 \\
0 \\
0 \\
0\end{array}$ & $\begin{array}{l}0 \\
0 \\
0 \\
0 \\
0\end{array}$ & $\begin{array}{l}\bar{N} \\
\bar{N} \\
\bar{N}\end{array}$ & $\begin{array}{l}\bar{N} \\
\mathrm{~N} \\
\bar{N}\end{array}$ & $\begin{array}{r}1 \\
1 \\
- \\
-\end{array}$ & $\begin{array}{l}3 \\
0 \\
1 \\
0 \\
1\end{array}$ & $\begin{array}{r}21 \\
3 \\
20 \\
1 \\
4\end{array}$ & $\begin{array}{r}11 \\
5 \\
2 \\
4\end{array}$ & $\begin{array}{l}8 \\
4 \\
1 \\
1 \\
2\end{array}$ \\
\hline $\begin{array}{l}\text { W.S. Central } \\
\text { Arkansas } \\
\text { Louisiana } \\
\text { Oklahoma } \\
\text { Texas }\end{array}$ & $\begin{array}{r}592 \\
130 \\
267 \\
195 \\
-\end{array}$ & $\begin{array}{r}1,939 \\
170 \\
221 \\
226 \\
1,319\end{array}$ & $\begin{array}{r}3,373 \\
340 \\
760 \\
2,160 \\
1,699\end{array}$ & $\begin{array}{r}20,610 \\
1,967 \\
1,417 \\
2,527 \\
14,699\end{array}$ & $\begin{array}{r}29,134 \\
2,183 \\
4,500 \\
2,588 \\
19,863\end{array}$ & $\begin{array}{l}- \\
\mathrm{N} \\
\mathrm{N} \\
\mathrm{N}\end{array}$ & $\begin{array}{l}0 \\
0 \\
0 \\
0 \\
0\end{array}$ & $\begin{array}{l}1 \\
0 \\
1 \\
0 \\
0\end{array}$ & $\begin{array}{l}- \\
\mathrm{N} \\
\mathrm{N} \\
\mathrm{N}\end{array}$ & $\begin{array}{l}- \\
\mathrm{N} \\
\mathrm{N} \\
\mathrm{N}\end{array}$ & $\begin{array}{r}1 \\
1 \\
- \\
-\end{array}$ & $\begin{array}{l}3 \\
0 \\
0 \\
0 \\
1\end{array}$ & $\begin{array}{r}30 \\
1 \\
21 \\
10 \\
14\end{array}$ & $\begin{array}{r}27 \\
2 \\
4 \\
11 \\
10\end{array}$ & $\begin{array}{l}15 \\
3 \\
6 \\
6\end{array}$ \\
\hline $\begin{array}{l}\text { Mountain } \\
\text { Arizona } \\
\text { Colorado } \\
\text { Idaho } \\
\text { Montana } \\
\text { Nevada } \\
\text { New Mexico§ } \\
\text { Utah } \\
\text { Wyoming }\end{array}$ & $\begin{array}{r}355 \\
320 \\
\overline{-} \\
\overline{10} \\
\overline{-} \\
-\end{array}$ & $\begin{array}{r}1,098 \\
311 \\
273 \\
45 \\
42 \\
134 \\
149 \\
87 \\
23\end{array}$ & $\begin{array}{r}1,705 \\
536 \\
480 \\
235 \\
181 \\
448 \\
338 \\
138 \\
43\end{array}$ & $\begin{array}{r}9,980 \\
4,072 \\
1,396 \\
450 \\
283 \\
1,102 \\
1,766 \\
639 \\
272\end{array}$ & $\begin{array}{r}15,424 \\
5,475 \\
3,711 \\
413 \\
583 \\
1,869 \\
2,001 \\
1,096 \\
276\end{array}$ & $\begin{array}{r}185 \\
185 \\
N \\
N \\
N \\
- \\
- \\
-\end{array}$ & $\begin{array}{r}77 \\
76 \\
0 \\
0 \\
0 \\
1 \\
0 \\
0 \\
0\end{array}$ & $\begin{array}{r}229 \\
225 \\
0 \\
0 \\
0 \\
4 \\
2 \\
3 \\
2\end{array}$ & $\begin{array}{r}1,779 \\
1,755 \\
N \\
N \\
N \\
14 \\
8 \\
2\end{array}$ & $\begin{array}{r}626 \\
596 \\
N \\
N \\
N \\
23 \\
5 \\
2 \\
-\end{array}$ & $\begin{array}{l}- \\
- \\
- \\
- \\
-\end{array}$ & $\begin{array}{l}2 \\
0 \\
1 \\
0 \\
0 \\
0 \\
0 \\
0 \\
0\end{array}$ & $\begin{array}{l}9 \\
1 \\
3 \\
2 \\
3 \\
1 \\
3 \\
3 \\
1\end{array}$ & $\begin{array}{r}18 \\
2 \\
4 \\
1 \\
4 \\
1 \\
-6 \\
-\end{array}$ & $\begin{array}{r}31 \\
3 \\
8 \\
3 \\
5 \\
6 \\
4 \\
2\end{array}$ \\
\hline $\begin{array}{l}\text { Pacific } \\
\text { Alaska } \\
\text { California } \\
\text { Hawaii } \\
\text { Oregon }^{\S} \\
\text { Washington }\end{array}$ & $\begin{array}{r}1,784 \\
77 \\
1,137 \\
- \\
278 \\
292\end{array}$ & $\begin{array}{r}3,156 \\
77 \\
2,450 \\
106 \\
171 \\
359\end{array}$ & $\begin{array}{r}4,914 \\
121 \\
4,148 \\
134 \\
315 \\
604\end{array}$ & $\begin{array}{r}35,915 \\
859 \\
27,109 \\
1,282 \\
2,075 \\
4,590\end{array}$ & $\begin{array}{r}41,428 \\
947 \\
31,873 \\
1,352 \\
2,269 \\
4,987\end{array}$ & $\begin{array}{l}10 \\
10 \\
N \\
N \\
N\end{array}$ & $\begin{array}{r}27 \\
0 \\
27 \\
0 \\
0 \\
0\end{array}$ & $\begin{array}{r}1,114 \\
0 \\
1,114 \\
0 \\
0 \\
0\end{array}$ & $\begin{array}{r}431 \\
-731 \\
N \\
N \\
N\end{array}$ & $\begin{array}{r}428 \\
-728 \\
N \\
N \\
N\end{array}$ & $\begin{array}{l}\frac{1}{-} \\
\frac{1}{-}\end{array}$ & $\begin{array}{l}6 \\
0 \\
3 \\
0 \\
1 \\
0\end{array}$ & $\begin{array}{r}50 \\
2 \\
14 \\
1 \\
20 \\
36\end{array}$ & $\frac{18}{-}$ & $\begin{array}{l}\frac{67}{54} \\
\frac{8}{5}\end{array}$ \\
\hline $\begin{array}{l}\text { American Samoa } \\
\text { C.N.M.I. } \\
\text { Guam } \\
\text { Puerto Rico } \\
\text { U.S. Virgin Islands }\end{array}$ & $\frac{U}{\frac{U}{39}}$ & $\begin{array}{r}0 \\
0 \\
0 \\
79 \\
4\end{array}$ & $\begin{array}{r}0 \\
0 \\
0 \\
141 \\
8\end{array}$ & $\frac{U}{\frac{U}{1,185}}$ & $\begin{array}{r}U \\
U \\
64 \\
1,024 \\
105\end{array}$ & $\frac{U}{U} \frac{\mathrm{U}}{-}$ & $\begin{array}{l}0 \\
0 \\
0 \\
0 \\
0\end{array}$ & $\begin{array}{l}0 \\
0 \\
0 \\
0 \\
0\end{array}$ & $\frac{U}{U}$ & $\frac{U}{U}$ & $\frac{U}{\mathrm{U}}$ & $\begin{array}{l}0 \\
0 \\
0 \\
0 \\
0\end{array}$ & $\begin{array}{l}0 \\
0 \\
0 \\
0 \\
0\end{array}$ & $\begin{array}{l}U \\
\frac{U}{N} \\
-\end{array}$ & $\frac{U}{U}$ \\
\hline
\end{tabular}

C.N.M.I.: Commonwealth of Northern Mariana Islands.

U: Unavailable. - No reported cases. N: Not notifiable. Cum: Cumulative year-to-date counts.

Med: Median.

Max: Maximum.

* Incidence data for reporting years 2005 and 2006 are provisional.

Chlamydia refers to genital infections caused by Chlamydia trachomatis.

$\S$ Contains data reported through the National Electronic Disease Surveillance System (NEDSS). 
TABLE II. (Continued) Provisional cases of selected notifiable diseases, United States, weeks ending April 1, 2006, and April 2, 2005 (13th Week)*

\begin{tabular}{|c|c|c|c|c|c|c|c|c|c|c|c|c|c|c|c|}
\hline \multirow[b]{3}{*}{ Reporting area } & \multicolumn{5}{|c|}{ Giardiasis } & \multicolumn{5}{|c|}{ Gonorrhea } & \multicolumn{5}{|c|}{$\begin{array}{l}\text { Haemophilus influenzae, invasive } \\
\text { All ages, all serotypes }\end{array}$} \\
\hline & \multirow{2}{*}{$\begin{array}{c}\text { Current } \\
\text { week }\end{array}$} & \multicolumn{2}{|c|}{$\begin{array}{l}\text { Previous } \\
52 \text { weeks }\end{array}$} & \multirow{2}{*}{$\begin{array}{l}\text { Cum } \\
2006\end{array}$} & \multirow{2}{*}{$\begin{array}{l}\text { Cum } \\
2005\end{array}$} & \multirow{2}{*}{$\begin{array}{c}\text { Current } \\
\text { week }\end{array}$} & \multicolumn{2}{|c|}{$\begin{array}{l}\text { Previous } \\
52 \text { weeks }\end{array}$} & \multirow{2}{*}{$\begin{array}{l}\text { Cum } \\
2006 \\
\end{array}$} & \multirow{2}{*}{$\begin{array}{l}\text { Cum } \\
2005\end{array}$} & \multirow{2}{*}{$\begin{array}{c}\text { Current } \\
\text { week }\end{array}$} & \multicolumn{2}{|c|}{$\begin{array}{l}\text { Previous } \\
52 \text { weeks }\end{array}$} & \multirow{2}{*}{$\begin{array}{l}\text { Cum } \\
2006\end{array}$} & \multirow{2}{*}{$\begin{array}{l}\text { Cum } \\
2005 \\
\end{array}$} \\
\hline & & Med & Max & & & & Med & Max & & & & Med & Max & & \\
\hline United States & 212 & 320 & 770 & 3,014 & 3,817 & 4,344 & 6,255 & 8,242 & 71,833 & 79,343 & 32 & 37 & 97 & 507 & 645 \\
\hline $\begin{array}{l}\text { New England } \\
\text { Connecticut } \\
\text { Maine } \\
\text { Massachusetts } \\
\text { New Hampshire } \\
\text { Rhode Island } \\
\text { Vermont }^{\dagger}\end{array}$ & $\begin{array}{l}\frac{7}{-1} \\
1 \\
1 \\
4\end{array}$ & $\begin{array}{r}27 \\
1 \\
4 \\
11 \\
1 \\
0 \\
3\end{array}$ & $\begin{array}{r}90 \\
65 \\
11 \\
34 \\
7 \\
25 \\
9\end{array}$ & $\begin{array}{r}195 \\
23 \\
14 \\
103 \\
6 \\
13 \\
36\end{array}$ & $\begin{array}{r}273 \\
21 \\
39 \\
150 \\
11 \\
17 \\
35\end{array}$ & $\begin{array}{r}57 \\
- \\
46 \\
2 \\
7 \\
2\end{array}$ & $\begin{array}{r}105 \\
39 \\
2 \\
49 \\
4 \\
8 \\
1\end{array}$ & $\begin{array}{r}285 \\
238 \\
6 \\
78 \\
9 \\
25 \\
4\end{array}$ & $\begin{array}{r}1,086 \\
253 \\
31 \\
611 \\
59 \\
118 \\
14\end{array}$ & $\begin{array}{r}1,251 \\
319 \\
38 \\
715 \\
32 \\
138 \\
9\end{array}$ & $\begin{array}{l}\frac{1}{-} \\
\frac{1}{-} \\
-\end{array}$ & $\begin{array}{l}3 \\
0 \\
0 \\
1 \\
0 \\
0 \\
0\end{array}$ & $\begin{array}{r}12 \\
8 \\
1 \\
5 \\
3 \\
5 \\
1\end{array}$ & $\begin{array}{r}33 \\
8 \\
4 \\
4 \\
16 \\
2 \\
1 \\
2\end{array}$ & $\begin{array}{r}42 \\
14 \\
2 \\
18 \\
4 \\
4\end{array}$ \\
\hline $\begin{array}{l}\text { Mid. Atlantic } \\
\text { New Jersey } \\
\text { New York (Upstate) } \\
\text { New York City } \\
\text { Pennsylvania }\end{array}$ & $\begin{array}{r}32 \\
1 \\
22 \\
1 \\
8\end{array}$ & $\begin{array}{r}63 \\
7 \\
22 \\
15 \\
16\end{array}$ & $\begin{array}{r}242 \\
17 \\
216 \\
33 \\
29\end{array}$ & $\begin{array}{r}433 \\
3 \\
198 \\
69 \\
163\end{array}$ & $\begin{array}{l}743 \\
129 \\
211 \\
214 \\
189\end{array}$ & $\begin{array}{r}456 \\
51 \\
170 \\
111 \\
124\end{array}$ & $\begin{array}{l}632 \\
106 \\
122 \\
168 \\
214\end{array}$ & $\begin{array}{r}1,013 \\
150 \\
445 \\
405 \\
390\end{array}$ & $\begin{array}{r}5,777 \\
1,012 \\
1,397 \\
584 \\
2,784\end{array}$ & $\begin{array}{l}8,248 \\
1,432 \\
1,555 \\
2,504 \\
2,757\end{array}$ & $\frac{\frac{11}{9}}{2}$ & $\begin{array}{l}7 \\
1 \\
2 \\
1 \\
3\end{array}$ & $\begin{array}{r}28 \\
4 \\
25 \\
4 \\
8\end{array}$ & $\begin{array}{r}89 \\
1 \\
31 \\
8 \\
49\end{array}$ & $\begin{array}{r}110 \\
17 \\
33 \\
20 \\
40\end{array}$ \\
\hline $\begin{array}{l}\text { E.N. Central } \\
\text { Illinois } \\
\text { Indiana } \\
\text { Michigan } \\
\text { Ohio } \\
\text { Wisconsin }\end{array}$ & $\begin{array}{r}22 \\
N \\
1 \\
21 \\
-\end{array}$ & $\begin{array}{r}55 \\
13 \\
0 \\
15 \\
16 \\
12\end{array}$ & $\begin{array}{r}102 \\
32 \\
0 \\
29 \\
34 \\
33\end{array}$ & $\begin{array}{r}431 \\
24 \\
\mathrm{~N} \\
150 \\
190 \\
67\end{array}$ & $\begin{array}{r}608 \\
159 \\
\mathrm{~N} \\
171 \\
131 \\
147\end{array}$ & $\begin{array}{r}748 \\
149 \\
129 \\
383 \\
48 \\
39\end{array}$ & $\begin{array}{r}1,359 \\
393 \\
161 \\
258 \\
378 \\
119\end{array}$ & $\begin{array}{r}1,887 \\
761 \\
234 \\
822 \\
681 \\
171\end{array}$ & $\begin{array}{r}17,933 \\
3,938 \\
2,239 \\
6,268 \\
3,798 \\
1,690\end{array}$ & $\begin{array}{r}14,610 \\
3,635 \\
1,994 \\
2,028 \\
5,540 \\
1,413\end{array}$ & $\begin{array}{l}\frac{2}{-} \\
- \\
-\end{array}$ & $\begin{array}{l}6 \\
1 \\
1 \\
0 \\
2 \\
1\end{array}$ & $\begin{array}{r}14 \\
5 \\
6 \\
3 \\
6 \\
3\end{array}$ & $\begin{array}{r}65 \\
14 \\
12 \\
12 \\
21 \\
6\end{array}$ & $\begin{array}{r}105 \\
29 \\
18 \\
8 \\
40 \\
10\end{array}$ \\
\hline $\begin{array}{l}\text { W.N. Central } \\
\text { lowa } \\
\text { Kansas } \\
\text { Minnesota } \\
\text { Missouri } \\
\text { Nebraska }^{\dagger} \\
\text { North Dakota }^{\text {South Dakota }}\end{array}$ & $\begin{array}{l}11 \\
1 \\
2 \\
4 \\
4 \\
-\end{array}$ & $\begin{array}{r}34 \\
5 \\
4 \\
14 \\
10 \\
1 \\
0 \\
2\end{array}$ & $\begin{array}{r}142 \\
14 \\
9 \\
113 \\
32 \\
6 \\
3 \\
7\end{array}$ & $\begin{array}{r}307 \\
51 \\
37 \\
77 \\
104 \\
19 \\
2 \\
17\end{array}$ & $\begin{array}{r}460 \\
61 \\
42 \\
204 \\
103 \\
29 \\
1 \\
20\end{array}$ & $\begin{array}{r}212 \\
20 \\
55 \\
\frac{-}{95} \\
35 \\
\frac{7}{7}\end{array}$ & $\begin{array}{r}362 \\
31 \\
48 \\
63 \\
181 \\
21 \\
2 \\
6\end{array}$ & $\begin{array}{r}461 \\
54 \\
124 \\
89 \\
240 \\
55 \\
6 \\
15\end{array}$ & $\begin{array}{r}4,225 \\
410 \\
606 \\
527 \\
2,264 \\
307 \\
20 \\
91\end{array}$ & $\begin{array}{r}4,677 \\
383 \\
640 \\
892 \\
2,354 \\
305 \\
21 \\
82\end{array}$ & $\begin{array}{l}1 \\
- \\
- \\
- \\
- \\
-\end{array}$ & $\begin{array}{l}1 \\
0 \\
0 \\
0 \\
0 \\
0 \\
0 \\
0\end{array}$ & $\begin{array}{l}9 \\
0 \\
2 \\
9 \\
7 \\
1 \\
2 \\
0\end{array}$ & $\begin{array}{r}26 \\
3 \\
10 \\
11 \\
2 \\
- \\
-\end{array}$ & $\begin{array}{r}29 \\
1 \\
1 \\
13 \\
10 \\
3 \\
1 \\
-\end{array}$ \\
\hline $\begin{array}{l}\text { S. Atlantic } \\
\text { Delaware } \\
\text { District of Columbia } \\
\text { Florida } \\
\text { Georgia } \\
\text { Maryland } \\
\text { North Carolina }^{\text {South Carolina }}{ }^{\dagger} \\
\text { Virginia }^{\dagger} \\
\text { West Virginia }^{\text {Westa }}\end{array}$ & $\begin{array}{l}60 \\
\frac{-}{29} \\
\frac{31}{\mathrm{~N}} \\
\frac{-}{-}\end{array}$ & $\begin{array}{r}49 \\
1 \\
1 \\
19 \\
10 \\
4 \\
0 \\
1 \\
10 \\
0\end{array}$ & $\begin{array}{r}83 \\
3 \\
5 \\
40 \\
32 \\
11 \\
0 \\
9 \\
50 \\
6\end{array}$ & $\begin{array}{r}593 \\
5 \\
15 \\
230 \\
183 \\
46 \\
\mathrm{~N} \\
20 \\
92 \\
2\end{array}$ & $\begin{array}{r}580 \\
14 \\
12 \\
201 \\
159 \\
39 \\
\mathrm{~N} \\
29 \\
119 \\
7\end{array}$ & $\begin{array}{r}1,674 \\
28 \\
30 \\
310 \\
10 \\
29 \\
385 \\
704 \\
149 \\
29\end{array}$ & $\begin{array}{r}1,439 \\
19 \\
40 \\
399 \\
262 \\
135 \\
272 \\
131 \\
148 \\
14\end{array}$ & $\begin{array}{r}2,281 \\
44 \\
67 \\
513 \\
913 \\
242 \\
766 \\
783 \\
289 \\
34\end{array}$ & $\begin{array}{r}16,802 \\
374 \\
361 \\
5,132 \\
1,628 \\
1,710 \\
4,108 \\
1,752 \\
1,488 \\
249\end{array}$ & $\begin{array}{r}19,785 \\
190 \\
534 \\
4,772 \\
3,265 \\
1,713 \\
4,444 \\
2,448 \\
2,249 \\
170\end{array}$ & $\begin{array}{l}10 \\
- \\
4 \\
1 \\
1 \\
- \\
-2 \\
2\end{array}$ & $\begin{array}{l}9 \\
0 \\
0 \\
3 \\
1 \\
1 \\
0 \\
1 \\
1 \\
0\end{array}$ & $\begin{array}{r}25 \\
0 \\
0 \\
12 \\
6 \\
5 \\
11 \\
3 \\
8 \\
4\end{array}$ & $\begin{array}{r}135 \\
- \\
46 \\
27 \\
17 \\
14 \\
10 \\
15 \\
6\end{array}$ & $\begin{array}{r}161 \\
- \\
34 \\
44 \\
24 \\
24 \\
6 \\
17 \\
12\end{array}$ \\
\hline $\begin{array}{l}\text { E.S. Central } \\
\text { Alabama }^{\dagger} \\
\text { Kentucky } \\
\text { Mississippi } \\
\text { Tennessee }^{\dagger}\end{array}$ & $\begin{array}{r}5 \\
3 \\
\mathrm{~N} \\
2\end{array}$ & $\begin{array}{l}8 \\
4 \\
0 \\
0 \\
4\end{array}$ & $\begin{array}{r}19 \\
13 \\
0 \\
0 \\
11\end{array}$ & $\begin{array}{r}89 \\
42 \\
N \\
47\end{array}$ & $\begin{array}{r}95 \\
48 \\
\mathrm{~N} \\
47\end{array}$ & $\begin{array}{r}429 \\
181 \\
89 \\
159\end{array}$ & $\begin{array}{r}536 \\
183 \\
51 \\
133 \\
173\end{array}$ & $\begin{array}{l}868 \\
491 \\
107 \\
225 \\
284\end{array}$ & $\begin{array}{r}6,714 \\
2,249 \\
824 \\
1,351 \\
2,290\end{array}$ & $\begin{array}{r}6,279 \\
1,498 \\
942 \\
1,709 \\
2,130\end{array}$ & $\begin{array}{r}2 \\
1 \\
- \\
1\end{array}$ & $\begin{array}{l}2 \\
0 \\
0 \\
0 \\
2\end{array}$ & $\begin{array}{l}8 \\
4 \\
3 \\
0 \\
5\end{array}$ & $\begin{array}{l}33 \\
10 \\
- \\
23\end{array}$ & $\begin{array}{r}30 \\
5 \\
1 \\
24\end{array}$ \\
\hline $\begin{array}{l}\text { W.S. Central } \\
\text { Arkansas } \\
\text { Louisiana } \\
\text { Oklahoma } \\
\text { Texas }^{\dagger}\end{array}$ & $\begin{array}{l}- \\
\bar{E} \\
\bar{N}\end{array}$ & $\begin{array}{l}6 \\
2 \\
1 \\
3 \\
0\end{array}$ & $\begin{array}{r}23 \\
5 \\
6 \\
16 \\
0\end{array}$ & $\begin{array}{r}53 \\
18 \\
15 \\
20 \\
\mathrm{~N}\end{array}$ & $\begin{array}{r}58 \\
19 \\
8 \\
31 \\
\mathrm{~N}\end{array}$ & $\begin{array}{r}335 \\
77 \\
177 \\
81 \\
-\end{array}$ & $\begin{array}{r}775 \\
87 \\
122 \\
83 \\
485\end{array}$ & $\begin{array}{r}1,304 \\
187 \\
461 \\
763 \\
629\end{array}$ & $\begin{array}{r}8,247 \\
1,136 \\
945 \\
833 \\
5,333\end{array}$ & $\begin{array}{r}11,466 \\
1,116 \\
2,420 \\
1,168 \\
6,762\end{array}$ & $\begin{array}{l}- \\
- \\
-\end{array}$ & $\begin{array}{l}2 \\
0 \\
0 \\
1 \\
0\end{array}$ & $\begin{array}{l}6 \\
2 \\
3 \\
4 \\
1\end{array}$ & $\begin{array}{r}27 \\
2 \\
4 \\
21 \\
-\end{array}$ & $\begin{array}{l}39 \\
20 \\
19 \\
-\end{array}$ \\
\hline $\begin{array}{l}\text { Mountain } \\
\text { Arizona } \\
\text { Colorado } \\
\text { Idaho }^{\dagger} \\
\text { Montana } \\
\text { Nevada }^{\dagger} \\
\text { New Mexico } \\
\text { Utah } \\
\text { Wyoming }\end{array}$ & $\begin{array}{r}20 \\
1 \\
11 \\
- \\
- \\
-6 \\
-\end{array}$ & $\begin{array}{r}27 \\
2 \\
9 \\
2 \\
1 \\
2 \\
1 \\
7 \\
1\end{array}$ & $\begin{array}{r}58 \\
12 \\
33 \\
12 \\
7 \\
6 \\
6 \\
20 \\
2\end{array}$ & $\begin{array}{r}291 \\
35 \\
111 \\
19 \\
17 \\
9 \\
7 \\
88 \\
5\end{array}$ & $\begin{array}{r}289 \\
49 \\
97 \\
30 \\
9 \\
19 \\
13 \\
69 \\
3\end{array}$ & $\begin{array}{l}73 \\
68 \\
- \\
- \\
- \\
- \\
- \\
-\end{array}$ & $\begin{array}{r}228 \\
69 \\
61 \\
1 \\
2 \\
53 \\
28 \\
15 \\
2\end{array}$ & $\begin{array}{r}519 \\
166 \\
90 \\
10 \\
13 \\
195 \\
64 \\
22 \\
6\end{array}$ & $\begin{array}{r}2,357 \\
942 \\
434 \\
25 \\
18 \\
433 \\
320 \\
144 \\
41\end{array}$ & $\begin{array}{r}3,234 \\
1,166 \\
749 \\
19 \\
41 \\
706 \\
361 \\
177 \\
15\end{array}$ & $\begin{array}{l}4 \\
- \\
- \\
- \\
- \\
-\end{array}$ & $\begin{array}{l}4 \\
1 \\
1 \\
0 \\
0 \\
0 \\
0 \\
0 \\
0\end{array}$ & $\begin{array}{r}10 \\
9 \\
5 \\
1 \\
0 \\
1 \\
3 \\
2 \\
2\end{array}$ & $\begin{array}{r}70 \\
28 \\
22 \\
1 \\
- \\
10 \\
8 \\
1\end{array}$ & $\begin{array}{r}84 \\
35 \\
20 \\
2 \\
10 \\
11 \\
5 \\
1\end{array}$ \\
\hline $\begin{array}{l}\text { Pacific } \\
\text { Alaska } \\
\text { California } \\
\text { Hawaii } \\
\text { Oregon }^{\dagger} \\
\text { Washington }^{+}\end{array}$ & $\begin{array}{r}55 \\
1 \\
38 \\
1 \\
6 \\
9\end{array}$ & $\begin{array}{r}61 \\
2 \\
43 \\
1 \\
8 \\
6\end{array}$ & $\begin{array}{r}189 \\
6 \\
95 \\
6 \\
21 \\
88\end{array}$ & $\begin{array}{r}622 \\
5 \\
465 \\
13 \\
95 \\
44\end{array}$ & $\begin{array}{r}711 \\
13 \\
570 \\
19 \\
73 \\
36\end{array}$ & $\begin{array}{r}360 \\
5 \\
254 \\
-22 \\
79\end{array}$ & $\begin{array}{r}784 \\
10 \\
649 \\
19 \\
28 \\
72\end{array}$ & $\begin{array}{r}938 \\
23 \\
804 \\
36 \\
58 \\
142\end{array}$ & $\begin{array}{r}8,692 \\
107 \\
7,057 \\
228 \\
280 \\
1,020\end{array}$ & $\begin{array}{r}9,793 \\
121 \\
8,145 \\
249 \\
405 \\
873\end{array}$ & $\frac{1}{-}$ & $\begin{array}{l}3 \\
0 \\
1 \\
0 \\
2 \\
0\end{array}$ & $\begin{array}{r}20 \\
19 \\
8 \\
2 \\
8 \\
4\end{array}$ & $\begin{array}{r}29 \\
2 \\
3 \\
3 \\
20 \\
1\end{array}$ & $\begin{array}{r}45 \\
2 \\
12 \\
1 \\
30 \\
-\end{array}$ \\
\hline $\begin{array}{l}\text { American Samoa } \\
\text { C.N.M.I. } \\
\text { Guam } \\
\text { Puerto Rico } \\
\text { U.S. Virgin Islands }\end{array}$ & $\frac{U}{U} \frac{U}{-}$ & $\begin{array}{l}0 \\
0 \\
0 \\
3 \\
0\end{array}$ & $\begin{array}{r}0 \\
0 \\
0 \\
14 \\
0\end{array}$ & $\frac{U}{\frac{U}{3}}$ & $\frac{U}{U}$ & $\begin{array}{l}U \\
\frac{U}{1} \\
-\end{array}$ & $\begin{array}{l}0 \\
0 \\
0 \\
6 \\
0\end{array}$ & $\begin{array}{r}0 \\
0 \\
0 \\
16 \\
4\end{array}$ & $\begin{array}{l}U \\
\frac{U}{92} \\
\end{array}$ & $\begin{array}{r}U \\
U \\
1 \\
108 \\
35\end{array}$ & $\begin{array}{l}U \\
U \\
- \\
-\end{array}$ & $\begin{array}{l}0 \\
0 \\
0 \\
0 \\
0\end{array}$ & $\begin{array}{l}0 \\
0 \\
0 \\
1 \\
0\end{array}$ & $\begin{array}{l}U \\
U \\
- \\
-\end{array}$ & $\begin{array}{l}U \\
U \\
- \\
-\end{array}$ \\
\hline
\end{tabular}

C.N.M.I.: Commonwealth of Northern Mariana Islands

$\mathrm{U}$ : Unavailable. $\quad-$ : No reported cases. N: Not notifiable.

Cum: Cumulative year-to-date counts.

Med: Median

Max: Maximum.

Contains data reported through the National Electronic Disease Surveillance System (NEDSS). 
TABLE II. (Continued) Provisional cases of selected notifiable diseases, United States, weeks ending April 1, 2006, and April 2, 2005 (13th Week)*

\begin{tabular}{|c|c|c|c|c|c|c|c|c|c|c|c|c|c|c|c|}
\hline \multirow[b]{4}{*}{ Reporting area } & \multicolumn{10}{|c|}{ Hepatitis (viral, acute), by type } & \multirow{2}{*}{\multicolumn{5}{|c|}{ Legionellosis }} \\
\hline & \multicolumn{5}{|c|}{$\mathbf{A}$} & \multicolumn{5}{|c|}{ B } & & & & & \\
\hline & \multirow{2}{*}{$\begin{array}{c}\text { Current } \\
\text { week }\end{array}$} & \multicolumn{2}{|c|}{$\begin{array}{l}\text { Previous } \\
52 \text { weeks }\end{array}$} & \multirow{2}{*}{$\begin{array}{l}\text { Cum } \\
2006 \\
\end{array}$} & \multirow{2}{*}{$\begin{array}{l}\text { Cum } \\
2005 \\
\end{array}$} & \multirow{2}{*}{$\begin{array}{c}\text { Current } \\
\text { week }\end{array}$} & \multicolumn{2}{|c|}{$\begin{array}{l}\text { Previous } \\
52 \text { weeks } \\
\end{array}$} & \multirow{2}{*}{$\begin{array}{l}\text { Cum } \\
2006 \\
\end{array}$} & \multirow{2}{*}{$\begin{array}{l}\text { Cum } \\
2005\end{array}$} & \multirow{2}{*}{$\begin{array}{c}\text { Current } \\
\text { week }\end{array}$} & \multicolumn{2}{|c|}{$\begin{array}{l}\text { Previous } \\
52 \text { weeks } \\
\end{array}$} & \multirow{2}{*}{$\begin{array}{l}\text { Cum } \\
2006 \\
\end{array}$} & \multirow{2}{*}{$\begin{array}{l}\text { Cum } \\
2005 \\
\end{array}$} \\
\hline & & Med & $\operatorname{Max}$ & & & & Med & Max & & & & Med & Max & & \\
\hline United States & 52 & 79 & 216 & 860 & 1,018 & 41 & 96 & 469 & 945 & 1,329 & 16 & 40 & 112 & 268 & 270 \\
\hline $\begin{array}{l}\text { New England } \\
\text { Connecticut } \\
\text { Maine } \\
\text { Massachusetts } \\
\text { New Hampshire } \\
\text { Rhode Island } \\
\text { Vermont }^{\dagger}\end{array}$ & $\begin{array}{l}- \\
- \\
- \\
-\end{array}$ & $\begin{array}{l}7 \\
1 \\
0 \\
5 \\
1 \\
0 \\
0\end{array}$ & $\begin{array}{r}23 \\
3 \\
2 \\
14 \\
12 \\
4 \\
2\end{array}$ & $\begin{array}{r}54 \\
8 \\
2 \\
28 \\
10 \\
1 \\
5\end{array}$ & $\begin{array}{r}128 \\
16 \\
93 \\
14 \\
5 \\
-\end{array}$ & $\begin{array}{l}- \\
- \\
- \\
-\end{array}$ & $\begin{array}{l}4 \\
0 \\
0 \\
3 \\
0 \\
0 \\
0\end{array}$ & $\begin{array}{r}11 \\
5 \\
2 \\
10 \\
3 \\
2 \\
1\end{array}$ & $\begin{array}{r}38 \\
1 \\
32 \\
4 \\
1 \\
-\end{array}$ & $\begin{array}{r}69 \\
15 \\
4 \\
46 \\
3 \\
1\end{array}$ & $\begin{array}{l}- \\
- \\
- \\
-\end{array}$ & $\begin{array}{l}2 \\
0 \\
0 \\
1 \\
0 \\
0 \\
0\end{array}$ & $\begin{array}{r}11 \\
8 \\
1 \\
5 \\
1 \\
10 \\
3\end{array}$ & $\begin{array}{r}12 \\
4 \\
1 \\
5 \\
1 \\
-1\end{array}$ & $\begin{array}{r}12 \\
2 \\
1 \\
7 \\
2 \\
- \\
-\end{array}$ \\
\hline $\begin{array}{l}\text { Mid. Atlantic } \\
\text { New Jersey } \\
\text { New York (Upstate) } \\
\text { New York City } \\
\text { Pennsylvania }\end{array}$ & $\begin{array}{l}- \\
- \\
-\end{array}$ & $\begin{array}{r}11 \\
3 \\
1 \\
4 \\
1\end{array}$ & $\begin{array}{r}23 \\
11 \\
22 \\
12 \\
6\end{array}$ & $\begin{array}{r}38 \\
10 \\
11 \\
5 \\
12\end{array}$ & $\begin{array}{r}185 \\
35 \\
24 \\
95 \\
31\end{array}$ & $\frac{6}{\frac{6}{3}}$ & $\begin{array}{r}10 \\
2 \\
1 \\
2 \\
3\end{array}$ & $\begin{array}{r}25 \\
7 \\
14 \\
7 \\
9\end{array}$ & $\begin{array}{r}82 \\
24 \\
13 \\
5 \\
40\end{array}$ & $\begin{array}{r}175 \\
39 \\
26 \\
42 \\
68\end{array}$ & $\frac{4}{\frac{1}{3}}$ & $\begin{array}{r}11 \\
1 \\
4 \\
1 \\
5\end{array}$ & $\begin{array}{l}53 \\
12 \\
28 \\
20 \\
17\end{array}$ & $\begin{array}{r}73 \\
5 \\
31 \\
2 \\
35\end{array}$ & $\begin{array}{r}77 \\
11 \\
19 \\
7 \\
40\end{array}$ \\
\hline $\begin{array}{l}\text { E.N. Central } \\
\text { Illinois } \\
\text { Indiana } \\
\text { Michigan } \\
\text { Ohio } \\
\text { Wisconsin }\end{array}$ & $\begin{array}{l}\frac{5}{-} \\
\frac{5}{-}\end{array}$ & $\begin{array}{l}7 \\
1 \\
1 \\
2 \\
1 \\
0\end{array}$ & $\begin{array}{r}17 \\
9 \\
10 \\
11 \\
4 \\
5\end{array}$ & $\begin{array}{r}64 \\
11 \\
3 \\
29 \\
20 \\
1\end{array}$ & $\begin{array}{r}107 \\
38 \\
5 \\
28 \\
22 \\
14\end{array}$ & $\begin{array}{l}5 \\
1 \\
1 \\
3 \\
-\end{array}$ & $\begin{array}{l}9 \\
2 \\
0 \\
3 \\
2 \\
0\end{array}$ & $\begin{array}{r}25 \\
7 \\
15 \\
7 \\
8 \\
6\end{array}$ & $\begin{array}{r}75 \\
5 \\
40 \\
28 \\
2\end{array}$ & $\begin{array}{r}140 \\
40 \\
5 \\
49 \\
39 \\
7\end{array}$ & $\begin{array}{l}- \\
- \\
- \\
-\end{array}$ & $\begin{array}{l}7 \\
1 \\
0 \\
2 \\
3 \\
0\end{array}$ & $\begin{array}{r}26 \\
5 \\
6 \\
6 \\
19 \\
2\end{array}$ & $\begin{array}{r}41 \\
7 \\
2 \\
11 \\
21 \\
-\end{array}$ & $\begin{array}{r}64 \\
10 \\
4 \\
17 \\
27 \\
6\end{array}$ \\
\hline $\begin{array}{l}\text { W.N. Central } \\
\text { lowa } \\
\text { Kansas } \\
\text { Minnesota } \\
\text { Missouri } \\
\text { Nebraska }^{\dagger} \\
\text { North Dakota } \\
\text { South Dakota }\end{array}$ & $\begin{array}{l}- \\
- \\
- \\
- \\
-\end{array}$ & $\begin{array}{l}2 \\
0 \\
0 \\
0 \\
0 \\
0 \\
0 \\
0\end{array}$ & $\begin{array}{r}31 \\
2 \\
5 \\
31 \\
4 \\
3 \\
0 \\
1\end{array}$ & $\begin{array}{r}29 \\
2 \\
15 \\
1 \\
6 \\
3 \\
2\end{array}$ & $\begin{array}{r}33 \\
6 \\
4 \\
3 \\
18 \\
2 \\
- \\
-\end{array}$ & $\begin{array}{l}- \\
- \\
- \\
- \\
-\end{array}$ & $\begin{array}{l}4 \\
0 \\
0 \\
0 \\
3 \\
0 \\
0 \\
0\end{array}$ & $\begin{array}{r}13 \\
2 \\
3 \\
6 \\
7 \\
2 \\
0 \\
1\end{array}$ & $\begin{array}{r}21 \\
1 \\
2 \\
1 \\
17 \\
- \\
- \\
\end{array}$ & $\begin{array}{r}59 \\
3 \\
7 \\
39 \\
9 \\
1\end{array}$ & $\begin{array}{l}- \\
- \\
- \\
- \\
-\end{array}$ & $\begin{array}{l}1 \\
0 \\
0 \\
0 \\
0 \\
0 \\
0 \\
0\end{array}$ & $\begin{array}{r}12 \\
1 \\
1 \\
10 \\
3 \\
2 \\
1 \\
6\end{array}$ & $\begin{array}{l}7 \\
- \\
- \\
5 \\
2 \\
-\end{array}$ & $\begin{array}{l}9 \\
1 \\
1 \\
6 \\
-1 \\
-\end{array}$ \\
\hline $\begin{array}{l}\text { S. Atlantic } \\
\text { Delaware } \\
\text { District of Columbia } \\
\text { Florida } \\
\text { Georgia } \\
\text { Maryland } \\
\text { North Carolina }^{\text {South Carolina }}{ }^{\dagger} \\
\text { Virginia }^{\dagger} \\
\text { West Virginia }^{\text {Weln }}\end{array}$ & $\begin{array}{l}6 \\
- \\
-5 \\
- \\
- \\
-\end{array}$ & $\begin{array}{r}13 \\
0 \\
0 \\
5 \\
1 \\
2 \\
0 \\
1 \\
1 \\
0\end{array}$ & $\begin{array}{r}33 \\
1 \\
2 \\
18 \\
6 \\
7 \\
20 \\
3 \\
11 \\
2\end{array}$ & $\begin{array}{r}144 \\
3 \\
1 \\
54 \\
11 \\
23 \\
34 \\
5 \\
13 \\
-\end{array}$ & $\begin{array}{r}140 \\
2 \\
1 \\
53 \\
24 \\
12 \\
24 \\
4 \\
20 \\
-\end{array}$ & $\begin{array}{l}\frac{10}{-} \\
\frac{8}{1} \\
-1 \\
- \\
-\end{array}$ & $\begin{array}{r}23 \\
0 \\
0 \\
9 \\
2 \\
2 \\
0 \\
2 \\
2 \\
0\end{array}$ & $\begin{array}{r}60 \\
4 \\
4 \\
21 \\
7 \\
7 \\
8 \\
23 \\
9 \\
18 \\
14\end{array}$ & $\begin{array}{r}244 \\
4 \\
4 \\
105 \\
20 \\
39 \\
49 \\
13 \\
6 \\
4\end{array}$ & $\begin{array}{r}396 \\
11 \\
136 \\
68 \\
47 \\
42 \\
37 \\
48 \\
7\end{array}$ & $\begin{array}{r}9 \\
- \\
\overline{8} \\
-1 \\
- \\
- \\
-\end{array}$ & $\begin{array}{l}9 \\
0 \\
0 \\
2 \\
0 \\
2 \\
0 \\
0 \\
1 \\
0\end{array}$ & $\begin{array}{r}21 \\
4 \\
2 \\
6 \\
3 \\
9 \\
3 \\
2 \\
8 \\
3\end{array}$ & $\begin{array}{r}76 \\
1 \\
1 \\
35 \\
3 \\
18 \\
9 \\
1 \\
7 \\
1\end{array}$ & $\begin{array}{r}58 \\
1 \\
1 \\
21 \\
4 \\
17 \\
7 \\
4 \\
3\end{array}$ \\
\hline $\begin{array}{l}\text { E.S. Central } \\
\text { Alabama }^{\dagger} \\
\text { Kentucky } \\
\text { Mississippi } \\
\text { Tennessee }^{\dagger}\end{array}$ & $\begin{array}{l}- \\
- \\
-\end{array}$ & $\begin{array}{l}4 \\
0 \\
0 \\
0 \\
2\end{array}$ & $\begin{array}{r}16 \\
6 \\
4 \\
2 \\
13\end{array}$ & $\begin{array}{r}31 \\
2 \\
13 \\
1 \\
15\end{array}$ & $\begin{array}{r}38 \\
5 \\
3 \\
8 \\
22\end{array}$ & $\begin{array}{r}2 \\
1 \\
- \\
1\end{array}$ & $\begin{array}{l}6 \\
1 \\
1 \\
1 \\
2\end{array}$ & $\begin{array}{r}20 \\
7 \\
5 \\
4 \\
12\end{array}$ & $\begin{array}{r}63 \\
19 \\
15 \\
4 \\
25\end{array}$ & $\begin{array}{r}101 \\
21 \\
24 \\
21 \\
35\end{array}$ & $\begin{array}{l}- \\
- \\
-\end{array}$ & $\begin{array}{l}1 \\
0 \\
0 \\
0 \\
1\end{array}$ & $\begin{array}{l}6 \\
2 \\
4 \\
1 \\
4\end{array}$ & $\begin{array}{r}7 \\
-1 \\
-\end{array}$ & $\begin{array}{r}7 \\
5 \\
1 \\
1\end{array}$ \\
\hline $\begin{array}{l}\text { W.S. Central } \\
\text { Arkansas } \\
\text { Louisiana } \\
\text { Oklahoma } \\
\text { Texas }^{\dagger}\end{array}$ & $\begin{array}{r}5 \\
5 \\
- \\
- \\
-\end{array}$ & $\begin{array}{l}9 \\
0 \\
1 \\
0 \\
6\end{array}$ & $\begin{array}{r}52 \\
7 \\
5 \\
2 \\
49\end{array}$ & $\begin{array}{r}60 \\
15 \\
2 \\
4 \\
39\end{array}$ & $\begin{array}{r}80 \\
2 \\
18 \\
1 \\
59\end{array}$ & $\frac{3}{-}$ & $\begin{array}{r}14 \\
1 \\
1 \\
0 \\
12\end{array}$ & $\begin{array}{r}268 \\
3 \\
6 \\
5 \\
266\end{array}$ & $\begin{array}{r}264 \\
4 \\
6 \\
1 \\
253\end{array}$ & $\begin{array}{r}115 \\
17 \\
22 \\
13 \\
63\end{array}$ & $\frac{1}{-}$ & $\begin{array}{l}1 \\
0 \\
0 \\
0 \\
0\end{array}$ & $\begin{array}{r}26 \\
1 \\
2 \\
3 \\
26\end{array}$ & $\begin{array}{l}8 \\
4 \\
1 \\
3\end{array}$ & $\begin{array}{l}2 \\
1 \\
- \\
1\end{array}$ \\
\hline $\begin{array}{l}\text { Mountain } \\
\text { Arizona } \\
\text { Colorado } \\
\text { Idaho }^{\dagger} \\
\text { Montana } \\
\text { Nevada }^{\dagger} \\
\text { New Mexico }^{\dagger} \\
\text { Utah } \\
\text { Wyoming }\end{array}$ & $\begin{array}{l}2 \\
1 \\
1 \\
- \\
- \\
- \\
- \\
-\end{array}$ & $\begin{array}{l}6 \\
3 \\
1 \\
0 \\
0 \\
0 \\
0 \\
0 \\
0\end{array}$ & $\begin{array}{r}21 \\
20 \\
4 \\
3 \\
1 \\
2 \\
3 \\
3 \\
0\end{array}$ & $\begin{array}{r}88 \\
58 \\
15 \\
3 \\
1 \\
3 \\
5 \\
3 \\
-\end{array}$ & $\begin{array}{r}97 \\
53 \\
8 \\
10 \\
6 \\
5 \\
5 \\
9 \\
1\end{array}$ & $\begin{array}{l}3 \\
2 \\
1 \\
- \\
- \\
- \\
- \\
-\end{array}$ & $\begin{array}{l}8 \\
5 \\
1 \\
0 \\
0 \\
1 \\
0 \\
0 \\
0\end{array}$ & $\begin{array}{r}39 \\
34 \\
5 \\
2 \\
7 \\
4 \\
3 \\
5 \\
1\end{array}$ & $\begin{array}{r}60 \\
34 \\
9 \\
4 \\
-9 \\
1 \\
3 \\
\end{array}$ & $\begin{array}{r}117 \\
72 \\
10 \\
3 \\
-10 \\
7 \\
15 \\
-\end{array}$ & $\begin{array}{l}1 \\
1 \\
- \\
- \\
- \\
- \\
- \\
-\end{array}$ & $\begin{array}{l}2 \\
0 \\
0 \\
0 \\
0 \\
0 \\
0 \\
0 \\
0\end{array}$ & $\begin{array}{l}8 \\
3 \\
3 \\
2 \\
1 \\
2 \\
1 \\
2 \\
1\end{array}$ & $\begin{array}{r}13 \\
6 \\
1 \\
- \\
-3 \\
-3 \\
-\end{array}$ & $\begin{array}{r}22 \\
4 \\
4 \\
1 \\
1 \\
5 \\
2 \\
3 \\
2\end{array}$ \\
\hline $\begin{array}{l}\text { Pacific } \\
\text { Alaska } \\
\text { California } \\
\text { Hawaii } \\
\text { Oregon }{ }^{\dagger} \\
\text { Washington }\end{array}$ & $\frac{34}{\frac{33}{-}}$ & $\begin{array}{r}15 \\
0 \\
13 \\
0 \\
1 \\
1\end{array}$ & $\begin{array}{r}150 \\
1 \\
149 \\
2 \\
5 \\
5 \\
11\end{array}$ & $\begin{array}{r}352 \\
-\overline{329} \\
5 \\
10 \\
8\end{array}$ & $\begin{array}{r}210 \\
3 \\
176 \\
5 \\
11 \\
15\end{array}$ & $\begin{array}{l}\frac{12}{12} \\
- \\
-\end{array}$ & $\begin{array}{r}10 \\
0 \\
6 \\
0 \\
2 \\
0\end{array}$ & $\begin{array}{r}56 \\
2 \\
39 \\
1 \\
6 \\
13\end{array}$ & $\begin{array}{r}98 \\
1 \\
76 \\
1 \\
12 \\
8\end{array}$ & $\begin{array}{r}157 \\
1 \\
112 \\
1 \\
31 \\
12\end{array}$ & $\begin{array}{l}\frac{1}{1} \\
\frac{N}{-}\end{array}$ & $\begin{array}{l}1 \\
0 \\
1 \\
0 \\
0 \\
0\end{array}$ & $\begin{array}{l}9 \\
1 \\
9 \\
1 \\
0 \\
0\end{array}$ & $\frac{31}{\frac{31}{N}}$ & $\frac{\frac{19}{19}}{\frac{N}{-}}$ \\
\hline $\begin{array}{l}\text { American Samoa } \\
\text { C.N.M.I. } \\
\text { Guam } \\
\text { Puerto Rico } \\
\text { U.S. Virgin Islands }\end{array}$ & $\begin{array}{l}U \\
\\
- \\
-\end{array}$ & $\begin{array}{l}0 \\
0 \\
0 \\
0 \\
0\end{array}$ & $\begin{array}{l}1 \\
0 \\
0 \\
6 \\
0\end{array}$ & $\frac{U}{U}$ & $\frac{\bar{U}}{\frac{16}{-}}$ & $\begin{array}{l}U \\
U \\
- \\
-\end{array}$ & $\begin{array}{l}0 \\
0 \\
0 \\
1 \\
0\end{array}$ & $\begin{array}{l}0 \\
0 \\
0 \\
6 \\
0\end{array}$ & $\begin{array}{l}U \\
\frac{U}{3} \\
-\end{array}$ & $\frac{\bar{U}}{\frac{4}{-}}$ & $\begin{array}{l}U \\
U \\
- \\
-\end{array}$ & $\begin{array}{l}0 \\
0 \\
0 \\
0 \\
0\end{array}$ & $\begin{array}{l}0 \\
0 \\
0 \\
0 \\
0\end{array}$ & $\begin{array}{l}U \\
U \\
- \\
-\end{array}$ & $\begin{array}{l}U \\
U \\
- \\
-\end{array}$ \\
\hline
\end{tabular}

C.N.M.I.: Commonwealth of Northern Mariana Islands.

$\mathrm{U}:$ Unavailable. $\quad$-: No reported cases. N: Not notifiable.

Cum: Cumulative year-to-date counts.

Med: Median

Max: Maximum.

* Incidence data for reporting years 2005 and 2006 are provisional.

Contains data reported through the National Electronic Disease Surveillance System (NEDSS). 
TABLE II. (Continued) Provisional cases of selected notifiable diseases, United States, weeks ending April 1, 2006, and April 2, 2005 (13th Week)*

\begin{tabular}{|c|c|c|c|c|c|c|c|c|c|c|}
\hline \multirow[b]{4}{*}{ Reporting area } & \multicolumn{5}{|c|}{ Lyme disease } & \multicolumn{5}{|c|}{ Malaria } \\
\hline & \multirow{3}{*}{$\begin{array}{c}\text { Current } \\
\text { week }\end{array}$} & \multirow{2}{*}{\multicolumn{2}{|c|}{$\begin{array}{l}\text { Previous } \\
52 \text { weeks }\end{array}$}} & \multirow{3}{*}{$\begin{array}{l}\text { Cum } \\
2006 \\
\end{array}$} & \multirow{3}{*}{$\begin{array}{l}\text { Cum } \\
2005 \\
\end{array}$} & \multirow{3}{*}{$\begin{array}{c}\text { Current } \\
\text { week }\end{array}$} & & & & \\
\hline & & & & & & & & & Cum & Cum \\
\hline & & Med & Max & & & & Med & Max & 2006 & 2005 \\
\hline United States & 62 & 300 & 1,336 & 1,046 & 1,649 & 8 & 24 & 59 & 208 & 276 \\
\hline New England & - & 50 & 232 & 54 & 137 & - & 1 & 12 & 7 & 8 \\
\hline Connecticut & - & 9 & 154 & 31 & 6 & - & 0 & 10 & 1 & - \\
\hline Maine & - & 2 & 26 & 7 & 9 & - & 0 & 1 & - & - \\
\hline Massachusetts & - & 18 & 164 & 1 & 105 & - & 0 & 4 & 5 & 6 \\
\hline New Hampshire & - & 3 & 17 & 14 & 15 & - & 0 & 1 & - & 2 \\
\hline Rhode Island & - & 0 & 12 & - & 1 & - & 0 & 2 & - & - \\
\hline Vermont $^{\dagger}$ & - & 0 & 5 & 1 & 1 & - & 0 & 2 & 1 & - \\
\hline Mid. Atlantic & 57 & 180 & 915 & 693 & 1,075 & - & 5 & 15 & 26 & 69 \\
\hline New Jersey & - & 27 & 309 & 109 & 362 & - & 0 & 7 & - & 16 \\
\hline New York (Upstate) & 53 & 66 & 821 & 342 & 181 & - & 1 & 10 & 7 & 13 \\
\hline New York City & - & 0 & 0 & - & - & - & 3 & 8 & 11 & 33 \\
\hline Pennsylvania & 4 & 61 & 464 & 242 & 532 & - & 1 & 2 & 8 & 7 \\
\hline E.N. Central & - & 13 & 157 & 29 & 70 & 1 & 2 & 6 & 27 & 24 \\
\hline Illinois & - & 0 & 6 & - & 1 & - & 0 & 2 & 7 & 7 \\
\hline Indiana & - & 0 & 4 & - & 2 & - & 0 & 3 & 5 & 3 \\
\hline Michigan & - & 1 & 7 & 6 & 1 & - & 0 & 2 & 4 & 7 \\
\hline Ohio & - & 1 & 5 & 2 & 13 & - & 0 & 3 & 7 & 3 \\
\hline Wisconsin & - & 10 & 148 & $2 \overline{1}$ & 53 & 1 & 0 & 3 & 4 & 4 \\
\hline W.N. Central & - & 12 & 99 & 26 & 37 & - & 0 & 5 & 5 & 9 \\
\hline lowa & - & 1 & 8 & 1 & 4 & - & 0 & 1 & 1 & 2 \\
\hline Kansas & - & 0 & 3 & - & 2 & - & 0 & 1 & - & 1 \\
\hline Minnesota & - & 8 & 96 & 23 & 31 & - & 0 & 3 & 2 & 1 \\
\hline Missouri & - & 0 & 2 & 1 & - & - & 0 & 3 & $\overline{1}$ & 5 \\
\hline Nebraska $^{\dagger}$ & - & 0 & 2 & 1 & - & - & 0 & 2 & - & - \\
\hline North Dakota & - & 0 & 0 & - & - & - & 0 & 0 & - & - \\
\hline South Dakota & - & 0 & 1 & - & - & - & 0 & 1 & 1 & - \\
\hline S. Atlantic & 5 & 34 & 124 & 176 & 293 & 6 & 6 & 15 & 76 & 59 \\
\hline Delaware & - & 9 & 37 & 53 & 104 & - & 0 & 1 & - & 1 \\
\hline District of Columbia & - & 0 & 2 & 5 & 1 & - & 0 & 2 & - & 1 \\
\hline $\begin{array}{l}\text { Florida } \\
\text { Fluma }\end{array}$ & 1 & 1 & 8 & 11 & 9 & - & 1 & 6 & $\overline{10}$ & 13 \\
\hline Georgia & - & 0 & 1 & - & 1 & 4 & 0 & 6 & 21 & 9 \\
\hline Maryland & 3 & 16 & 86 & 97 & 142 & 1 & 1 & 9 & 21 & 18 \\
\hline North Carolina & 1 & 0 & 5 & 8 & 14 & 1 & 0 & 8 & 9 & 8 \\
\hline South Carolina ${ }^{\dagger}$ & - & 0 & 3 & 2 & 4 & - & 0 & 2 & 2 & 1 \\
\hline Virginia $^{\dagger}$ & - & 3 & 21 & - & 18 & - & 0 & 9 & 12 & 7 \\
\hline West Virginia & - & 0 & 42 & - & - & - & 0 & 2 & 1 & 1 \\
\hline E.S. Central & - & 0 & 4 & - & 5 & - & 1 & 2 & 5 & 6 \\
\hline Alabama $^{\dagger}$ & - & 0 & 1 & - & - & - & 0 & 1 & 2 & 1 \\
\hline Kentucky & - & 0 & 1 & - & 1 & - & 0 & 2 & 1 & 2 \\
\hline Mississippi & - & 0 & 0 & - & - & - & 0 & 0 & - & - \\
\hline Tennessee $^{\dagger}$ & - & 0 & 4 & - & 4 & - & 0 & 2 & 2 & 3 \\
\hline W.S. Central & - & 1 & 7 & 1 & 15 & - & 1 & 16 & 7 & 30 \\
\hline Arkansas & - & 0 & 2 & - & - & - & 0 & 2 & - & 2 \\
\hline Louisiana & - & 0 & 1 & - & 2 & - & 0 & 1 & - & 1 \\
\hline Oklahoma & - & 0 & 0 & - & - & - & 0 & 6 & 1 & 2 \\
\hline Texas $^{\dagger}$ & - & 1 & 7 & 1 & 13 & - & 1 & 15 & 6 & 25 \\
\hline Mountain & - & 0 & 4 & 2 & 1 & - & 1 & 6 & 13 & 14 \\
\hline Arizona & - & 0 & 4 & 2 & - & - & 0 & 4 & 1 & 2 \\
\hline Colorado & - & 0 & 1 & - & - & - & 0 & 3 & 4 & 7 \\
\hline Idaho $^{\dagger}$ & - & 0 & 1 & - & - & - & 0 & 0 & - & - \\
\hline Montana & - & 0 & 0 & - & - & - & 0 & 1 & 1 & - \\
\hline Nevada $^{\dagger}$ & - & 0 & 2 & - & - & - & 0 & 2 & - & - \\
\hline New Mexico ${ }^{\dagger}$ & - & 0 & 1 & - & - & - & 0 & 1 & - & 1 \\
\hline Utah & - & 0 & 1 & - & - & - & 0 & 2 & 7 & 3 \\
\hline Wyoming & - & 0 & 1 & - & 1 & - & 0 & 1 & - & 1 \\
\hline Pacific & - & 4 & 18 & 65 & 16 & 1 & 4 & 12 & 42 & 57 \\
\hline Alaska & - & 0 & 1 & - & 1 & 1 & 0 & 1 & 3 & 2 \\
\hline California & - & 2 & 18 & 65 & 14 & - & 3 & 10 & 31 & 47 \\
\hline Hawaii & $\mathrm{N}$ & 0 & 0 & $\mathrm{~N}$ & $\mathrm{~N}$ & - & 0 & 4 & - & 4 \\
\hline Oregon $^{\dagger}$ & - & 0 & 3 & - & 1 & - & 0 & 2 & 4 & 2 \\
\hline Washington & - & 0 & 3 & - & - & - & 0 & 5 & 4 & 2 \\
\hline American Samoa & $U$ & 0 & 0 & U & $U$ & $U$ & 0 & 0 & $U$ & $U$ \\
\hline C.N.M.I. & $U$ & 0 & 0 & U & $U$ & $U$ & 0 & 0 & $U$ & $U$ \\
\hline Guam & - & 0 & 0 & - & - & - & 0 & 0 & - & - \\
\hline Puerto Rico & $\bar{N}$ & 0 & 0 & $\bar{N}$ & $\bar{N}$ & - & 0 & 1 & - & - \\
\hline U.S. Virgin Islands & - & 0 & 0 & - & - & - & 0 & 0 & - & - \\
\hline
\end{tabular}

C.N.M.I.: Commonwealth of Northern Mariana Islands.

U: Unavailable. $\quad-$ : No reported cases. N: Not notifiable.

* Incidence data for reporting years 2005 and 2006 are provisional.

Cum: Cumulative year-to-date counts.

Med: Median

Max: Maximum.

${ }^{\dagger}$ Contains data reported through the National Electronic Disease Surveillance System (NEDSS). 
TABLE II. (Continued) Provisional cases of selected notifiable diseases, United States, weeks ending April 1, 2006, and April 2, 2005 (13th Week)*

\begin{tabular}{|c|c|c|c|c|c|c|c|c|c|c|c|c|c|c|c|}
\hline \multirow[b]{4}{*}{ Reporting area } & \multicolumn{10}{|c|}{ Meningococcal disease, invasive } & \multirow{2}{*}{\multicolumn{5}{|c|}{ Pertussis }} \\
\hline & \multirow{3}{*}{$\begin{array}{c}\text { Current } \\
\text { week }\end{array}$} & \multicolumn{4}{|c|}{ All serogroups } & \multicolumn{5}{|c|}{ Serogroup unknown } & & & & & \\
\hline & & & & \multirow{2}{*}{$\begin{array}{l}\text { Cum } \\
2006 \\
\end{array}$} & \multirow{2}{*}{$\begin{array}{l}\text { Cum } \\
2005 \\
\end{array}$} & \multirow{2}{*}{$\begin{array}{c}\text { Current } \\
\text { week }\end{array}$} & \multicolumn{2}{|c|}{$\begin{array}{l}\text { Previous } \\
52 \text { weeks } \\
\end{array}$} & \multirow{2}{*}{$\begin{array}{l}\text { Cum } \\
2006 \\
\end{array}$} & \multirow{2}{*}{$\begin{array}{l}\text { Cum } \\
2005\end{array}$} & \multirow{2}{*}{$\begin{array}{c}\text { Current } \\
\text { week }\end{array}$} & \multicolumn{2}{|c|}{$\begin{array}{l}\text { Previous } \\
52 \text { weeks }\end{array}$} & \multirow{2}{*}{$\begin{array}{l}\text { Cum } \\
2006 \\
\end{array}$} & \multirow{2}{*}{$\begin{array}{l}\text { Cum } \\
2005 \\
\end{array}$} \\
\hline & & Med & Max & & & & Med & $\operatorname{Max}$ & & & & Med & Max & & \\
\hline United States & 21 & 23 & 81 & 345 & 422 & 10 & 14 & 57 & 233 & 236 & 150 & 429 & 1,777 & 2,730 & 5,010 \\
\hline $\begin{array}{l}\text { New England } \\
\text { Connecticut } \\
\text { Maine } \\
\text { Massachusetts } \\
\text { New Hampshire } \\
\text { Rhode Island } \\
\text { Vermont }^{\dagger}\end{array}$ & $\begin{array}{l}- \\
- \\
- \\
-\end{array}$ & $\begin{array}{l}1 \\
0 \\
0 \\
0 \\
0 \\
0 \\
0\end{array}$ & $\begin{array}{l}5 \\
2 \\
1 \\
3 \\
2 \\
1 \\
1\end{array}$ & $\begin{array}{r}15 \\
3 \\
2 \\
8 \\
2 \\
- \\
\end{array}$ & $\begin{array}{r}28 \\
7 \\
1 \\
13 \\
3 \\
2 \\
2\end{array}$ & $\begin{array}{l}- \\
- \\
- \\
-\end{array}$ & $\begin{array}{l}1 \\
0 \\
0 \\
0 \\
0 \\
0 \\
0\end{array}$ & $\begin{array}{l}3 \\
2 \\
1 \\
3 \\
2 \\
0 \\
1\end{array}$ & $\begin{array}{r}15 \\
3 \\
2 \\
8 \\
2 \\
- \\
-\end{array}$ & $\begin{array}{l}9 \\
1 \\
1 \\
3 \\
3 \\
1\end{array}$ & $\begin{array}{l}\frac{1}{-} \\
-1 \\
- \\
-\end{array}$ & $\begin{array}{r}27 \\
0 \\
1 \\
21 \\
1 \\
0 \\
1\end{array}$ & $\begin{array}{r}55 \\
4 \\
5 \\
44 \\
15 \\
12 \\
6\end{array}$ & $\begin{array}{r}182 \\
12 \\
140 \\
8 \\
\frac{8}{22}\end{array}$ & $\begin{array}{r}336 \\
23 \\
14 \\
253 \\
5 \\
41\end{array}$ \\
\hline $\begin{array}{l}\text { Mid. Atlantic } \\
\text { New Jersey } \\
\text { New York (Upstate) } \\
\text { New York City } \\
\text { Pennsylvania }\end{array}$ & $\begin{array}{l}\frac{5}{5} \\
- \\
-\end{array}$ & $\begin{array}{l}2 \\
0 \\
0 \\
0 \\
1\end{array}$ & $\begin{array}{r}15 \\
2 \\
7 \\
5 \\
4\end{array}$ & $\begin{array}{r}33 \\
10 \\
3 \\
20\end{array}$ & $\begin{array}{r}50 \\
13 \\
13 \\
7 \\
17\end{array}$ & $\begin{array}{r}\frac{4}{4} \\
- \\
-\end{array}$ & $\begin{array}{l}2 \\
0 \\
0 \\
0 \\
1\end{array}$ & $\begin{array}{r}13 \\
2 \\
5 \\
5 \\
4\end{array}$ & $\begin{array}{r}28 \\
8 \\
3 \\
17\end{array}$ & $\begin{array}{r}37 \\
13 \\
4 \\
7 \\
13\end{array}$ & $\frac{46}{\frac{27}{19}}$ & $\begin{array}{r}22 \\
3 \\
10 \\
2 \\
8\end{array}$ & $\begin{array}{r}126 \\
9 \\
115 \\
6 \\
17\end{array}$ & $\begin{array}{r}341 \\
25 \\
125 \\
16 \\
175\end{array}$ & $\begin{array}{r}430 \\
58 \\
148 \\
26 \\
198\end{array}$ \\
\hline $\begin{array}{l}\text { E.N. Central } \\
\text { Illinois } \\
\text { Indiana } \\
\text { Michigan } \\
\text { Ohio } \\
\text { Wisconsin }\end{array}$ & $\begin{array}{l}\frac{8}{5} \\
\frac{3}{-}\end{array}$ & $\begin{array}{l}2 \\
0 \\
0 \\
1 \\
1 \\
0\end{array}$ & $\begin{array}{l}9 \\
4 \\
3 \\
3 \\
5 \\
1\end{array}$ & $\begin{array}{r}37 \\
8 \\
7 \\
8 \\
14 \\
-\end{array}$ & $\begin{array}{r}40 \\
8 \\
5 \\
8 \\
11 \\
8\end{array}$ & $\begin{array}{l}\frac{1}{1} \\
- \\
-\end{array}$ & $\begin{array}{l}1 \\
0 \\
0 \\
0 \\
0 \\
0\end{array}$ & $\begin{array}{l}6 \\
4 \\
2 \\
3 \\
4 \\
1\end{array}$ & $\begin{array}{r}25 \\
8 \\
2 \\
4 \\
11 \\
-\end{array}$ & $\begin{array}{r}34 \\
8 \\
2 \\
5 \\
11 \\
8\end{array}$ & $\begin{array}{r}21 \\
5 \\
1 \\
15 \\
-\end{array}$ & $\begin{array}{r}60 \\
13 \\
5 \\
5 \\
18 \\
19\end{array}$ & $\begin{array}{r}125 \\
31 \\
75 \\
26 \\
43 \\
41\end{array}$ & $\begin{array}{r}377 \\
10 \\
44 \\
98 \\
197 \\
28\end{array}$ & $\begin{array}{r}1,356 \\
238 \\
82 \\
77 \\
515 \\
444\end{array}$ \\
\hline $\begin{array}{l}\text { W.N. Central } \\
\text { lowa } \\
\text { Kansas } \\
\text { Minnesota } \\
\text { Missouri } \\
\text { Nebraska } \\
\text { North Dakota } \\
\text { South Dakota }\end{array}$ & $\begin{array}{l}- \\
- \\
- \\
- \\
-\end{array}$ & $\begin{array}{l}1 \\
0 \\
0 \\
0 \\
0 \\
0 \\
0 \\
0\end{array}$ & $\begin{array}{l}4 \\
2 \\
1 \\
2 \\
3 \\
1 \\
1 \\
1\end{array}$ & $\begin{array}{r}15 \\
1 \\
2 \\
8 \\
4 \\
-\end{array}$ & $\begin{array}{r}26 \\
9 \\
3 \\
5 \\
6 \\
2 \\
-1\end{array}$ & $\begin{array}{l}- \\
- \\
- \\
- \\
- \\
-\end{array}$ & $\begin{array}{l}0 \\
0 \\
0 \\
0 \\
0 \\
0 \\
0 \\
0\end{array}$ & $\begin{array}{l}3 \\
2 \\
1 \\
1 \\
2 \\
1 \\
1 \\
0\end{array}$ & $\begin{array}{r}6 \\
1 \\
1 \\
2 \\
2 \\
-\end{array}$ & $\begin{array}{r}10 \\
1 \\
3 \\
1 \\
3 \\
2 \\
-\end{array}$ & $\begin{array}{l}\frac{1}{1} \\
- \\
- \\
- \\
-\end{array}$ & $\begin{array}{r}58 \\
10 \\
11 \\
0 \\
10 \\
3 \\
0 \\
2\end{array}$ & $\begin{array}{r}205 \\
55 \\
29 \\
148 \\
39 \\
14 \\
28 \\
7\end{array}$ & $\begin{array}{r}337 \\
66 \\
122 \\
- \\
113 \\
32 \\
4 \\
-\end{array}$ & $\begin{array}{r}702 \\
247 \\
88 \\
93 \\
119 \\
71 \\
26 \\
58\end{array}$ \\
\hline $\begin{array}{l}\text { S. Atlantic } \\
\text { Delaware } \\
\text { District of Columbia } \\
\text { Florida } \\
\text { Georgia } \\
\text { Maryland } \\
\text { North Carolina }^{\text {South Carolina }}{ }^{\dagger} \\
\text { Virginia }^{\dagger} \\
\text { West Virginia }^{\text {Wesia }}\end{array}$ & $\begin{array}{l}2 \\
- \\
1 \\
1 \\
- \\
- \\
-\end{array}$ & $\begin{array}{l}4 \\
0 \\
0 \\
1 \\
0 \\
0 \\
0 \\
0 \\
1 \\
0\end{array}$ & $\begin{array}{r}14 \\
1 \\
0 \\
7 \\
2 \\
2 \\
11 \\
2 \\
4 \\
1\end{array}$ & $\begin{array}{r}60 \\
2 \\
25 \\
3 \\
6 \\
11 \\
5 \\
8 \\
\end{array}$ & $\begin{array}{r}68 \\
2 \\
26 \\
8 \\
7 \\
6 \\
10 \\
7 \\
2\end{array}$ & $\begin{array}{l}1 \\
- \\
-1 \\
- \\
- \\
-\end{array}$ & $\begin{array}{l}2 \\
0 \\
0 \\
1 \\
0 \\
0 \\
0 \\
0 \\
0 \\
0\end{array}$ & $\begin{array}{l}8 \\
1 \\
0 \\
6 \\
2 \\
2 \\
3 \\
1 \\
3 \\
1\end{array}$ & $\begin{array}{r}23 \\
2 \\
9 \\
3 \\
3 \\
3 \\
1 \\
2 \\
-\end{array}$ & $\begin{array}{r}29 \\
2 \\
9 \\
8 \\
- \\
7 \\
2 \\
1\end{array}$ & $\begin{array}{r}20 \\
- \\
\overline{8} \\
- \\
2 \\
9 \\
1 \\
-\end{array}$ & $\begin{array}{r}23 \\
0 \\
0 \\
4 \\
1 \\
4 \\
0 \\
5 \\
4 \\
0\end{array}$ & $\begin{array}{r}90 \\
1 \\
3 \\
14 \\
3 \\
8 \\
21 \\
22 \\
72 \\
5\end{array}$ & $\begin{array}{r}255 \\
1 \\
3 \\
64 \\
5 \\
56 \\
52 \\
30 \\
42 \\
2\end{array}$ & $\begin{array}{r}341 \\
11 \\
39 \\
12 \\
68 \\
21 \\
129 \\
43 \\
18\end{array}$ \\
\hline $\begin{array}{l}\text { E.S. Central } \\
\text { Alabama }^{\dagger} \\
\text { Kentucky } \\
\text { Mississippi } \\
\text { Tennessee }^{\dagger}\end{array}$ & $\begin{array}{l}1 \\
1 \\
- \\
-\end{array}$ & $\begin{array}{l}1 \\
0 \\
0 \\
0 \\
0\end{array}$ & $\begin{array}{l}4 \\
1 \\
2 \\
1 \\
2\end{array}$ & $\begin{array}{r}13 \\
3 \\
3 \\
1 \\
6\end{array}$ & $\begin{array}{r}20 \\
8 \\
4 \\
8\end{array}$ & $\begin{array}{l}1 \\
1 \\
- \\
-\end{array}$ & $\begin{array}{l}1 \\
0 \\
0 \\
0 \\
0\end{array}$ & $\begin{array}{l}4 \\
1 \\
2 \\
1 \\
2\end{array}$ & $\begin{array}{r}11 \\
3 \\
3 \\
1 \\
4\end{array}$ & $\begin{array}{l}14 \\
8 \\
4 \\
2\end{array}$ & $\begin{array}{r}4 \\
2 \\
- \\
2\end{array}$ & $\begin{array}{l}8 \\
1 \\
2 \\
1 \\
3\end{array}$ & $\begin{array}{r}25 \\
9 \\
10 \\
4 \\
17\end{array}$ & $\begin{array}{r}61 \\
17 \\
4 \\
9 \\
31\end{array}$ & $\begin{array}{r}138 \\
27 \\
44 \\
20 \\
47\end{array}$ \\
\hline $\begin{array}{l}\text { W.S. Central } \\
\text { Arkansas } \\
\text { Louisiana } \\
\text { Oklahoma } \\
\text { Texas }^{\dagger}\end{array}$ & $\frac{1}{-}$ & $\begin{array}{l}2 \\
0 \\
1 \\
0 \\
1\end{array}$ & $\begin{array}{r}21 \\
3 \\
4 \\
3 \\
15\end{array}$ & $\begin{array}{r}38 \\
3 \\
21 \\
6 \\
8\end{array}$ & $\begin{array}{r}39 \\
7 \\
13 \\
4 \\
15\end{array}$ & $\begin{array}{l}- \\
- \\
-\end{array}$ & $\begin{array}{l}1 \\
0 \\
0 \\
0 \\
0\end{array}$ & $\begin{array}{l}8 \\
2 \\
3 \\
3 \\
3\end{array}$ & $\begin{array}{r}17 \\
3 \\
11 \\
1 \\
2\end{array}$ & $\begin{array}{r}10 \\
1 \\
2 \\
1 \\
6\end{array}$ & $\begin{array}{l}- \\
- \\
-\end{array}$ & $\begin{array}{r}45 \\
4 \\
0 \\
0 \\
39\end{array}$ & $\begin{array}{r}160 \\
19 \\
3 \\
1 \\
155\end{array}$ & $\begin{array}{r}169 \\
18 \\
4 \\
3 \\
144\end{array}$ & $\begin{array}{r}171 \\
34 \\
12 \\
125\end{array}$ \\
\hline $\begin{array}{l}\text { Mountain } \\
\text { Arizona } \\
\text { Colorado } \\
\text { Idaho }^{\dagger} \\
\text { Montana } \\
\text { Nevada }^{\dagger} \\
\text { New Mexico }^{\dagger} \\
\text { Utah } \\
\text { Wyoming }\end{array}$ & $\begin{array}{l}- \\
- \\
- \\
- \\
- \\
-\end{array}$ & $\begin{array}{l}2 \\
0 \\
0 \\
0 \\
0 \\
0 \\
0 \\
0 \\
0\end{array}$ & $\begin{array}{l}7 \\
5 \\
2 \\
2 \\
0 \\
2 \\
2 \\
2 \\
0\end{array}$ & $\begin{array}{r}28 \\
14 \\
11 \\
1 \\
- \\
- \\
2 \\
-\end{array}$ & $\begin{array}{r}29 \\
11 \\
10 \\
1 \\
-2 \\
3 \\
2 \\
-\end{array}$ & $\begin{array}{l}- \\
- \\
- \\
- \\
-\end{array}$ & $\begin{array}{l}1 \\
0 \\
0 \\
0 \\
0 \\
0 \\
0 \\
0 \\
0\end{array}$ & $\begin{array}{l}5 \\
5 \\
1 \\
2 \\
0 \\
1 \\
2 \\
1 \\
0\end{array}$ & $\begin{array}{r}20 \\
14 \\
4 \\
1 \\
- \\
- \\
1 \\
-\end{array}$ & $\begin{array}{r}5 \\
2 \\
-1 \\
- \\
-2 \\
-\end{array}$ & $\begin{array}{r}48 \\
3 \\
15 \\
- \\
- \\
- \\
29 \\
1\end{array}$ & $\begin{array}{r}75 \\
16 \\
24 \\
3 \\
7 \\
0 \\
2 \\
15 \\
1\end{array}$ & $\begin{array}{r}144 \\
86 \\
41 \\
14 \\
29 \\
5 \\
9 \\
38 \\
4\end{array}$ & $\begin{array}{r}836 \\
136 \\
355 \\
15 \\
31 \\
8 \\
8 \\
270 \\
13\end{array}$ & $\begin{array}{r}1,036 \\
76 \\
466 \\
89 \\
217 \\
13 \\
66 \\
102 \\
7\end{array}$ \\
\hline $\begin{array}{l}\text { Pacific } \\
\text { Alaska } \\
\text { California } \\
\text { Hawaii } \\
\text { Oregon }^{\dagger} \\
\text { Washington }\end{array}$ & $\begin{array}{l}\frac{4}{3} \\
\frac{-}{1}\end{array}$ & $\begin{array}{l}5 \\
0 \\
2 \\
0 \\
2 \\
0\end{array}$ & $\begin{array}{r}30 \\
1 \\
9 \\
1 \\
8 \\
25\end{array}$ & $\begin{array}{r}106 \\
61 \\
1 \\
28 \\
16\end{array}$ & $\begin{array}{r}122 \\
1 \\
56 \\
7 \\
42 \\
16\end{array}$ & $\begin{array}{l}\frac{3}{3} \\
- \\
-\end{array}$ & $\begin{array}{l}4 \\
0 \\
2 \\
0 \\
1 \\
0\end{array}$ & $\begin{array}{r}20 \\
1 \\
9 \\
1 \\
6 \\
11\end{array}$ & $\begin{array}{r}88 \\
61 \\
1 \\
20 \\
6\end{array}$ & $\begin{array}{r}88 \\
1 \\
56 \\
26 \\
23 \\
23 \\
6\end{array}$ & $\begin{array}{l}\frac{9}{-} \\
- \\
\end{array}$ & $\begin{array}{r}70 \\
2 \\
40 \\
3 \\
5 \\
12\end{array}$ & $\begin{array}{r}1,192 \\
15 \\
1,000 \\
10 \\
33 \\
189\end{array}$ & $\begin{array}{r}172 \\
24 \\
1 \\
22 \\
46 \\
79\end{array}$ & $\begin{array}{r}500 \\
11 \\
133 \\
37 \\
234 \\
85\end{array}$ \\
\hline $\begin{array}{l}\text { American Samoa } \\
\text { C.N.M.I. } \\
\text { Guam } \\
\text { Puerto Rico } \\
\text { U.S. Virgin Islands }\end{array}$ & $\begin{array}{l}U \\
\\
- \\
-\end{array}$ & $\begin{array}{l}0 \\
0 \\
0 \\
0 \\
0\end{array}$ & $\begin{array}{l}1 \\
0 \\
0 \\
1 \\
0\end{array}$ & $\begin{array}{l}- \\
- \\
-\end{array}$ & $\begin{array}{l}- \\
\overline{4} \\
-\end{array}$ & $\begin{array}{l}U \\
U \\
- \\
-\end{array}$ & $\begin{array}{l}0 \\
0 \\
0 \\
0 \\
0\end{array}$ & $\begin{array}{l}1 \\
0 \\
0 \\
1 \\
0\end{array}$ & $\begin{array}{l}U \\
U \\
- \\
-\end{array}$ & $\begin{array}{l}U \\
\frac{U}{4} \\
-\end{array}$ & $\begin{array}{l}U \\
U \\
- \\
-\end{array}$ & $\begin{array}{l}0 \\
0 \\
0 \\
0 \\
0\end{array}$ & $\begin{array}{l}0 \\
0 \\
0 \\
2 \\
0\end{array}$ & $\begin{array}{l}U \\
U \\
- \\
-\end{array}$ & $\begin{array}{l}U \\
\frac{U}{1} \\
\end{array}$ \\
\hline
\end{tabular}

C.N.M.I.: Commonwealth of Northern Mariana Islands

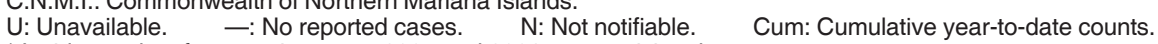

Med: Median.

Max: Maximum.

* Incidence data for reporting years 2005 and 2006 are provisional.

Contains data reported through the National Electronic Disease Surveillance System (NEDSS). 
TABLE II. (Continued) Provisional cases of selected notifiable diseases, United States, weeks ending April 1, 2006, and April 2, 2005 (13th Week)*

\begin{tabular}{|c|c|c|c|c|c|c|c|c|c|c|c|c|c|c|c|}
\hline \multirow[b]{3}{*}{ Reporting area } & \multicolumn{5}{|c|}{ Rabies, animal } & \multicolumn{5}{|c|}{ Rocky Mountain spotted fever } & \multicolumn{5}{|c|}{ Salmonellosis } \\
\hline & \multirow{2}{*}{$\begin{array}{c}\text { Current } \\
\text { week }\end{array}$} & \multicolumn{2}{|c|}{$\begin{array}{l}\text { Previous } \\
52 \text { weeks } \\
\end{array}$} & \multirow{2}{*}{$\begin{array}{l}\text { Cum } \\
2006 \\
\end{array}$} & \multirow{2}{*}{$\begin{array}{l}\text { Cum } \\
2005\end{array}$} & \multirow{2}{*}{$\begin{array}{c}\text { Current } \\
\text { week }\end{array}$} & \multicolumn{2}{|c|}{$\begin{array}{l}\text { Previous } \\
52 \text { weeks }\end{array}$} & \multirow{2}{*}{$\begin{array}{l}\text { Cum } \\
2006\end{array}$} & \multirow{2}{*}{$\begin{array}{l}\text { Cum } \\
2005\end{array}$} & \multirow{2}{*}{$\begin{array}{c}\text { Current } \\
\text { week }\end{array}$} & \multicolumn{2}{|c|}{$\begin{array}{l}\text { Previous } \\
52 \text { weeks }\end{array}$} & \multirow{2}{*}{$\begin{array}{l}\text { Cum } \\
2006 \\
\end{array}$} & \multirow{2}{*}{$\begin{array}{l}\text { Cum } \\
2005 \\
\end{array}$} \\
\hline & & Med & Max & & & & Med & $\operatorname{Max}$ & & & & Med & Max & & \\
\hline United States & 55 & 105 & 165 & 874 & 1,388 & 13 & 34 & 99 & 278 & 142 & 358 & 866 & 1,965 & 5,907 & 6,008 \\
\hline $\begin{array}{l}\text { New England } \\
\text { Connecticut } \\
\text { Maine } \\
\text { Massachusetts } \\
\text { New Hampshire } \\
\text { Rhode Island } \\
\text { Vermont }^{+}\end{array}$ & $\begin{array}{l}\frac{12}{1} \\
11 \\
- \\
-\end{array}$ & $\begin{array}{r}12 \\
3 \\
1 \\
4 \\
0 \\
0 \\
1\end{array}$ & $\begin{array}{r}33 \\
13 \\
4 \\
22 \\
3 \\
4 \\
7\end{array}$ & $\begin{array}{r}114 \\
23 \\
14 \\
60 \\
4 \\
1 \\
12\end{array}$ & $\begin{array}{r}165 \\
21 \\
11 \\
115 \\
2 \\
2 \\
14\end{array}$ & $\begin{array}{l}\overline{-} \\
\bar{N} \\
\overline{-} \\
-\end{array}$ & $\begin{array}{l}0 \\
0 \\
0 \\
0 \\
0 \\
0 \\
0\end{array}$ & $\begin{array}{l}1 \\
0 \\
0 \\
1 \\
1 \\
0 \\
0\end{array}$ & $\begin{array}{l}\overline{-} \\
\bar{N} \\
\overline{-} \\
-\end{array}$ & $\begin{array}{l}\frac{1}{N} \\
\frac{-}{1} \\
-\end{array}$ & $\begin{array}{l}\frac{4}{-} \\
\frac{2}{2} \\
-\end{array}$ & $\begin{array}{r}40 \\
8 \\
3 \\
20 \\
2 \\
0 \\
1\end{array}$ & $\begin{array}{r}78 \\
71 \\
8 \\
41 \\
12 \\
17 \\
10\end{array}$ & $\begin{array}{r}291 \\
71 \\
11 \\
178 \\
17 \\
11 \\
3\end{array}$ & $\begin{array}{r}319 \\
72 \\
22 \\
178 \\
19 \\
11 \\
17\end{array}$ \\
\hline $\begin{array}{l}\text { Mid. Atlantic } \\
\text { New Jersey } \\
\text { New York (Upstate) } \\
\text { New York City } \\
\text { Pennsylvania }\end{array}$ & $\begin{array}{r}11 \\
N \\
11 \\
-\end{array}$ & $\begin{array}{r}18 \\
0 \\
11 \\
0 \\
7\end{array}$ & $\begin{array}{r}40 \\
0 \\
24 \\
3 \\
22\end{array}$ & $\begin{array}{r}135 \\
\mathrm{~N} \\
81 \\
54\end{array}$ & $\begin{array}{r}168 \\
\mathrm{~N} \\
74 \\
7 \\
87\end{array}$ & $\begin{array}{l}\overline{-} \\
\overline{-} \\
-\end{array}$ & $\begin{array}{l}1 \\
0 \\
0 \\
0 \\
1\end{array}$ & $\begin{array}{l}8 \\
2 \\
2 \\
2 \\
6\end{array}$ & $\begin{array}{l}\frac{4}{-} \\
\frac{2}{2} \\
2\end{array}$ & $\begin{array}{l}8 \\
1 \\
1 \\
6\end{array}$ & $\begin{array}{r}41 \\
30 \\
1 \\
10\end{array}$ & $\begin{array}{l}93 \\
17 \\
21 \\
24 \\
31\end{array}$ & $\begin{array}{r}238 \\
41 \\
199 \\
43 \\
61\end{array}$ & $\begin{array}{r}552 \\
45 \\
153 \\
111 \\
243\end{array}$ & $\begin{array}{l}738 \\
144 \\
169 \\
209 \\
216\end{array}$ \\
\hline $\begin{array}{l}\text { E.N. Central } \\
\text { Illinois } \\
\text { Indiana } \\
\text { Michigan } \\
\text { Ohio } \\
\text { Wisconsin }\end{array}$ & $\begin{array}{l}- \\
\overline{-} \\
\bar{N}\end{array}$ & $\begin{array}{l}2 \\
1 \\
0 \\
0 \\
0 \\
0\end{array}$ & $\begin{array}{r}19 \\
4 \\
3 \\
4 \\
12 \\
3\end{array}$ & $\begin{array}{l}5 \\
- \\
3 \\
2 \\
N\end{array}$ & $\begin{array}{r}11 \\
3 \\
1 \\
3 \\
4 \\
\mathrm{~N}\end{array}$ & $\begin{array}{l}= \\
\overline{-} \\
= \\
-\end{array}$ & $\begin{array}{l}0 \\
0 \\
0 \\
0 \\
0 \\
0\end{array}$ & $\begin{array}{l}6 \\
3 \\
1 \\
1 \\
3 \\
1\end{array}$ & $\begin{array}{l}2 \\
1 \\
- \\
1 \\
-\end{array}$ & $\begin{array}{l}3 \\
1 \\
-1 \\
1 \\
-\end{array}$ & $\begin{array}{l}56 \\
\frac{2}{28} \\
2 \\
26 \\
-\end{array}$ & $\begin{array}{l}97 \\
30 \\
11 \\
17 \\
24 \\
15\end{array}$ & $\begin{array}{r}206 \\
124 \\
71 \\
35 \\
52 \\
45\end{array}$ & $\begin{array}{l}732 \\
114 \\
101 \\
143 \\
259 \\
115\end{array}$ & $\begin{array}{r}778 \\
237 \\
52 \\
164 \\
163 \\
162\end{array}$ \\
\hline $\begin{array}{l}\text { W.N. Central } \\
\text { lowa } \\
\text { Kansas } \\
\text { Minnesota } \\
\text { Missouri } \\
\text { Nebraska }^{\dagger} \\
\text { North Dakota } \\
\text { South Dakota }\end{array}$ & $\begin{array}{l}\frac{2}{2} \\
= \\
= \\
-\end{array}$ & $\begin{array}{l}6 \\
1 \\
1 \\
1 \\
1 \\
0 \\
0 \\
1\end{array}$ & $\begin{array}{r}23 \\
10 \\
4 \\
5 \\
7 \\
0 \\
4 \\
6\end{array}$ & $\begin{array}{r}39 \\
13 \\
11 \\
2 \\
3 \\
-2 \\
8\end{array}$ & $\begin{array}{r}68 \\
14 \\
21 \\
12 \\
7 \\
\\
1 \\
13\end{array}$ & $\begin{array}{l}\frac{1}{1} \\
= \\
= \\
- \\
-\end{array}$ & $\begin{array}{l}2 \\
0 \\
0 \\
0 \\
1 \\
0 \\
0 \\
0\end{array}$ & $\begin{array}{r}16 \\
2 \\
2 \\
1 \\
14 \\
2 \\
0 \\
2\end{array}$ & $\begin{array}{l}\frac{5}{1} \\
\frac{1}{4} \\
- \\
-\end{array}$ & $\begin{array}{l}\frac{4}{-} \\
\overline{4} \\
- \\
-\end{array}$ & $\begin{array}{l}17 \\
1 \\
7 \\
7 \\
2 \\
-\end{array}$ & $\begin{array}{r}42 \\
7 \\
7 \\
10 \\
14 \\
14 \\
2 \\
0 \\
2\end{array}$ & $\begin{array}{r}92 \\
18 \\
17 \\
31 \\
40 \\
10 \\
5 \\
11\end{array}$ & $\begin{array}{r}386 \\
50 \\
61 \\
97 \\
124 \\
30 \\
1 \\
23\end{array}$ & $\begin{array}{r}403 \\
76 \\
42 \\
105 \\
107 \\
37 \\
8 \\
28\end{array}$ \\
\hline $\begin{array}{l}\text { S. Atlantic } \\
\text { Delaware } \\
\text { District of Columbia } \\
\text { Florida } \\
\text { Georgia } \\
\text { Maryland } \\
\text { North Carolina } \\
\text { South Carolina }^{\dagger} \\
\text { Virginia }^{\dagger} \\
\text { West Virginia }\end{array}$ & $\begin{array}{l}\frac{15}{-} \\
- \\
\overline{1} \\
\frac{7}{7} \\
-\end{array}$ & $\begin{array}{r}34 \\
0 \\
0 \\
0 \\
4 \\
6 \\
8 \\
4 \\
10 \\
0\end{array}$ & $\begin{array}{r}54 \\
0 \\
0 \\
15 \\
15 \\
16 \\
19 \\
11 \\
26 \\
13\end{array}$ & $\begin{array}{r}356 \\
\overline{46} \\
16 \\
59 \\
77 \\
\frac{1}{142} \\
16\end{array}$ & $\begin{array}{r}632 \\
- \\
201 \\
70 \\
76 \\
107 \\
39 \\
134 \\
5\end{array}$ & $\begin{array}{l}\frac{12}{z} \\
= \\
\overline{-} \\
\frac{12}{-} \\
-\end{array}$ & $\begin{array}{r}17 \\
0 \\
0 \\
0 \\
1 \\
2 \\
4 \\
1 \\
2 \\
0\end{array}$ & $\begin{array}{r}95 \\
2 \\
1 \\
3 \\
9 \\
7 \\
87 \\
6 \\
10 \\
2\end{array}$ & $\begin{array}{r}259 \\
2 \\
-6 \\
15 \\
13 \\
218 \\
3 \\
2 \\
-\end{array}$ & $\begin{array}{r}104 \\
1 \\
5 \\
4 \\
5 \\
80 \\
6 \\
2 \\
1\end{array}$ & $\begin{array}{r}101 \\
\overline{-} \\
66 \\
12 \\
5 \\
15 \\
\frac{-}{3}\end{array}$ & $\begin{array}{r}257 \\
2 \\
1 \\
99 \\
34 \\
14 \\
32 \\
21 \\
20 \\
3\end{array}$ & $\begin{array}{r}507 \\
9 \\
7 \\
730 \\
73 \\
39 \\
114 \\
146 \\
66 \\
13\end{array}$ & $\begin{array}{r}1,639 \\
12 \\
15 \\
712 \\
260 \\
110 \\
333 \\
61 \\
121 \\
15\end{array}$ & $\begin{array}{r}1,569 \\
12 \\
10 \\
608 \\
208 \\
124 \\
309 \\
126 \\
153 \\
19\end{array}$ \\
\hline $\begin{array}{l}\text { E.S. Central } \\
\text { Alabama }^{\dagger} \\
\text { Kentucky } \\
\text { Mississippi } \\
\text { Tennessee }^{\dagger}\end{array}$ & $\begin{array}{l}2 \\
2 \\
- \\
-\end{array}$ & $\begin{array}{l}2 \\
1 \\
0 \\
0 \\
1\end{array}$ & $\begin{array}{l}9 \\
5 \\
3 \\
1 \\
4\end{array}$ & $\begin{array}{r}38 \\
15 \\
4 \\
-19\end{array}$ & $\begin{array}{l}27 \\
\frac{18}{-} \\
9\end{array}$ & $\begin{array}{l}\overline{-} \\
\overline{-} \\
-\end{array}$ & $\begin{array}{l}5 \\
0 \\
0 \\
0 \\
3\end{array}$ & $\begin{array}{r}24 \\
9 \\
1 \\
3 \\
18\end{array}$ & $\begin{array}{l}4 \\
- \\
- \\
3\end{array}$ & $\begin{array}{r}5 \\
1 \\
- \\
4\end{array}$ & $\begin{array}{r}20 \\
12 \\
\frac{2}{6}\end{array}$ & $\begin{array}{r}56 \\
13 \\
7 \\
13 \\
14\end{array}$ & $\begin{array}{r}134 \\
39 \\
26 \\
66 \\
40\end{array}$ & $\begin{array}{r}314 \\
126 \\
55 \\
39 \\
94\end{array}$ & $\begin{array}{r}338 \\
103 \\
36 \\
48 \\
151\end{array}$ \\
\hline $\begin{array}{l}\text { W.S. Central } \\
\text { Arkansas } \\
\text { Louisiana } \\
\text { Oklahoma } \\
\text { Texas }^{\dagger}\end{array}$ & $\begin{array}{l}9 \\
2 \\
- \\
7\end{array}$ & $\begin{array}{r}13 \\
0 \\
0 \\
1 \\
12\end{array}$ & $\begin{array}{r}42 \\
3 \\
0 \\
7 \\
39\end{array}$ & $\begin{array}{r}143 \\
3 \\
11 \\
129\end{array}$ & $\begin{array}{r}241 \\
10 \\
26 \\
205\end{array}$ & $\begin{array}{l}\overline{-} \\
\overline{-} \\
-\end{array}$ & $\begin{array}{l}2 \\
0 \\
0 \\
0 \\
0\end{array}$ & $\begin{array}{r}34 \\
32 \\
2 \\
23 \\
8\end{array}$ & $\begin{array}{l}3 \\
3 \\
- \\
- \\
-\end{array}$ & $\begin{array}{l}\frac{1}{1} \\
- \\
-\end{array}$ & $\begin{array}{r}29 \\
8 \\
- \\
21\end{array}$ & $\begin{array}{r}85 \\
16 \\
15 \\
6 \\
45\end{array}$ & $\begin{array}{r}783 \\
67 \\
42 \\
26 \\
750\end{array}$ & $\begin{array}{r}686 \\
222 \\
62 \\
49 \\
353\end{array}$ & $\begin{array}{r}439 \\
56 \\
105 \\
52 \\
226\end{array}$ \\
\hline $\begin{array}{l}\text { Mountain } \\
\text { Arizona } \\
\text { Colorado } \\
\text { Idaho }^{+} \\
\text {Montana } \\
\text { Nevada }^{\dagger} \\
\text { New Mexico } \\
\text { Utah } \\
\text { Wyoming }\end{array}$ & $\begin{array}{l}1 \\
1 \\
- \\
- \\
= \\
- \\
-\end{array}$ & $\begin{array}{l}4 \\
2 \\
0 \\
0 \\
0 \\
0 \\
0 \\
0 \\
0\end{array}$ & $\begin{array}{r}19 \\
11 \\
2 \\
12 \\
3 \\
2 \\
1 \\
5 \\
2\end{array}$ & $\begin{array}{l}19 \\
19 \\
= \\
= \\
= \\
= \\
-\end{array}$ & $\begin{array}{l}48 \\
41 \\
- \\
- \\
-\overline{1} \\
-\overline{6}\end{array}$ & $\begin{array}{l}\overline{-} \\
\overline{-} \\
\overline{-} \\
\overline{-} \\
-\end{array}$ & $\begin{array}{l}0 \\
0 \\
0 \\
0 \\
0 \\
0 \\
0 \\
0 \\
0\end{array}$ & $\begin{array}{l}4 \\
4 \\
1 \\
2 \\
1 \\
0 \\
1 \\
1 \\
1\end{array}$ & $\begin{array}{l}1 \\
1 \\
= \\
= \\
- \\
- \\
-\end{array}$ & $\begin{array}{l}16 \\
12 \\
- \\
- \\
-1 \\
2 \\
1\end{array}$ & $\begin{array}{r}26 \\
6 \\
13 \\
-4 \\
- \\
-3 \\
-\end{array}$ & $\begin{array}{r}50 \\
13 \\
10 \\
2 \\
2 \\
3 \\
4 \\
5 \\
1\end{array}$ & $\begin{array}{r}112 \\
28 \\
45 \\
17 \\
16 \\
8 \\
13 \\
31 \\
12\end{array}$ & $\begin{array}{r}424 \\
132 \\
127 \\
16 \\
23 \\
23 \\
33 \\
56 \\
14\end{array}$ & $\begin{array}{r}377 \\
121 \\
94 \\
22 \\
18 \\
39 \\
35 \\
40 \\
8\end{array}$ \\
\hline $\begin{array}{l}\text { Pacific } \\
\text { Alaska } \\
\text { California } \\
\text { Hawaii } \\
\text { Oregon }^{\dagger} \\
\text { Washington }\end{array}$ & $\frac{3}{\frac{3}{u}}$ & $\begin{array}{l}4 \\
0 \\
3 \\
0 \\
0 \\
0\end{array}$ & $\begin{array}{r}15 \\
3 \\
15 \\
0 \\
1 \\
0\end{array}$ & $\begin{array}{r}25 \\
5 \\
20 \\
\\
U\end{array}$ & $\begin{array}{r}28 \\
1 \\
27 \\
- \\
U\end{array}$ & $\begin{array}{l}\overline{-} \\
\overline{-} \\
\bar{N}\end{array}$ & $\begin{array}{l}0 \\
0 \\
0 \\
0 \\
0 \\
0\end{array}$ & $\begin{array}{l}2 \\
0 \\
1 \\
0 \\
1 \\
0\end{array}$ & $\begin{array}{l}- \\
\overline{-} \\
\bar{N}\end{array}$ & $\begin{array}{l}- \\
\overline{-} \\
\overline{-}\end{array}$ & $\begin{array}{r}\frac{64}{49} \\
\frac{1}{1} \\
14\end{array}$ & $\begin{array}{r}99 \\
1 \\
76 \\
5 \\
8 \\
8\end{array}$ & $\begin{array}{r}416 \\
5 \\
286 \\
15 \\
25 \\
121\end{array}$ & $\begin{array}{r}883 \\
21 \\
673 \\
45 \\
74 \\
70\end{array}$ & $\begin{array}{r}1,047 \\
12 \\
822 \\
73 \\
70 \\
70\end{array}$ \\
\hline $\begin{array}{l}\text { American Samoa } \\
\text { C.N.M.I. } \\
\text { Guam } \\
\text { Puerto Rico } \\
\text { U.S. Virgin Islands }\end{array}$ & $\begin{array}{l}U \\
\\
-\end{array}$ & $\begin{array}{l}0 \\
0 \\
0 \\
2 \\
0\end{array}$ & $\begin{array}{l}0 \\
0 \\
0 \\
4 \\
0\end{array}$ & $\frac{U}{\frac{U}{26}}$ & $\frac{U}{\frac{U}{20}}$ & $\frac{U}{\mathrm{U}}$ & $\begin{array}{l}0 \\
0 \\
0 \\
0 \\
0\end{array}$ & $\begin{array}{l}0 \\
0 \\
0 \\
0 \\
0\end{array}$ & $\frac{U}{\mathrm{U}}$ & $\frac{U}{\mathrm{U}}$ & $\begin{array}{l}U \\
\\
-\end{array}$ & $\begin{array}{l}0 \\
0 \\
0 \\
7 \\
0\end{array}$ & $\begin{array}{r}2 \\
0 \\
0 \\
23 \\
0\end{array}$ & $\frac{U}{\frac{U}{12}}$ & $\begin{array}{r}1 \\
U \\
1 \\
87 \\
-\end{array}$ \\
\hline
\end{tabular}

C.N.M.I.: Commonwealth of Northern Mariana Islands.

$\mathrm{U}:$ Unavailable. $\quad-$ : No reported cases. N: Not notifiable.

Cum: Cumulative year-to-date counts.

Med: Median

Max: Maximum.

* Incidence data for reporting years 2005 and 2006 are provisional.

Contains data reported through the National Electronic Disease Surveillance System (NEDSS). 
TABLE II. (Continued) Provisional cases of selected notifiable diseases, United States, weeks ending April 1, 2006, and April 2, 2005 $(13$ th Week)*

\begin{tabular}{|c|c|c|c|c|c|c|c|c|c|c|c|c|c|c|c|}
\hline \multirow[b]{3}{*}{ Reporting area } & \multicolumn{5}{|c|}{ Shiga toxin-producing E. coli (STEC) ${ }^{\dagger}$} & \multicolumn{5}{|c|}{ Shigellosis } & \multicolumn{5}{|c|}{ Streptococcal disease, invasive, group A } \\
\hline & \multirow{2}{*}{$\begin{array}{c}\begin{array}{c}\text { Current } \\
\text { week }\end{array} \\
\end{array}$} & \multicolumn{2}{|c|}{$\begin{array}{l}\text { Previous } \\
52 \text { weeks } \\
\end{array}$} & \multirow{2}{*}{$\begin{array}{l}\text { Cum } \\
2006 \\
\end{array}$} & \multirow{2}{*}{$\begin{array}{l}\text { Cum } \\
2005 \\
\end{array}$} & \multirow{2}{*}{$\begin{array}{c}\begin{array}{c}\text { Current } \\
\text { week }\end{array} \\
\end{array}$} & \multicolumn{2}{|c|}{$\begin{array}{l}\text { Previous } \\
52 \text { weeks }\end{array}$} & \multirow{2}{*}{$\begin{array}{l}\text { Cum } \\
2006 \\
\end{array}$} & \multirow{2}{*}{$\begin{array}{l}\text { Cum } \\
2005 \\
\end{array}$} & \multirow{2}{*}{$\begin{array}{c}\begin{array}{c}\text { Current } \\
\text { week }\end{array} \\
\end{array}$} & \multicolumn{2}{|c|}{$\begin{array}{l}\text { Previous } \\
52 \text { weeks } \\
\end{array}$} & \multirow{2}{*}{$\begin{array}{l}\text { Cum } \\
2006 \\
\end{array}$} & \multirow{2}{*}{$\begin{array}{l}\text { Cum } \\
2005 \\
\end{array}$} \\
\hline & & Med & Max & & & & Med & $\operatorname{Max}$ & & & & Med & $\operatorname{Max}$ & & \\
\hline United States & 14 & 48 & 248 & 194 & 323 & 92 & 292 & 604 & 1,963 & 2,534 & 70 & 81 & 196 & 1,398 & 1,311 \\
\hline $\begin{array}{l}\text { New England } \\
\text { Connecticut } \\
\text { Maine } \\
\text { Massachusetts } \\
\text { New Hampshire } \\
\text { Rhode Island } \\
\text { Vermont } \$\end{array}$ & $\begin{array}{l}- \\
- \\
- \\
-\end{array}$ & $\begin{array}{l}4 \\
0 \\
0 \\
2 \\
0 \\
0 \\
0\end{array}$ & $\begin{array}{r}13 \\
4 \\
5 \\
7 \\
2 \\
2 \\
2\end{array}$ & $\begin{array}{l}\frac{13}{-} \\
\frac{11}{2} \\
\frac{1}{1}\end{array}$ & $\begin{array}{r}28 \\
12 \\
2 \\
11 \\
1 \\
1 \\
1\end{array}$ & $\begin{array}{l}\frac{2}{-} \\
\frac{2}{-} \\
-\end{array}$ & $\begin{array}{l}5 \\
1 \\
0 \\
4 \\
0 \\
0 \\
0\end{array}$ & $\begin{array}{r}17 \\
6 \\
3 \\
11 \\
4 \\
6 \\
4\end{array}$ & $\begin{array}{r}56 \\
6 \\
43 \\
3 \\
3 \\
1\end{array}$ & $\begin{array}{r}51 \\
12 \\
1 \\
30 \\
4 \\
1 \\
3\end{array}$ & $\begin{array}{l}\frac{1}{U} \\
\frac{-}{-} \\
-1\end{array}$ & $\begin{array}{l}4 \\
0 \\
0 \\
2 \\
0 \\
0 \\
0\end{array}$ & $\begin{array}{l}8 \\
0 \\
2 \\
7 \\
3 \\
3 \\
2\end{array}$ & $\begin{array}{r}44 \\
U \\
3 \\
28 \\
8 \\
3 \\
2\end{array}$ & $\begin{array}{r}50 \\
U \\
2 \\
35 \\
3 \\
3 \\
7\end{array}$ \\
\hline $\begin{array}{l}\text { Mid. Atlantic } \\
\text { New Jersey } \\
\text { New York (Upstate) } \\
\text { New York City } \\
\text { Pennsylvania }\end{array}$ & $\begin{array}{l}- \\
- \\
-\end{array}$ & $\begin{array}{l}6 \\
1 \\
2 \\
0 \\
2\end{array}$ & $\begin{array}{r}99 \\
7 \\
96 \\
2 \\
8\end{array}$ & $\begin{array}{l}\overline{-} \\
\frac{10}{-}\end{array}$ & $\begin{array}{r}33 \\
10 \\
13 \\
1 \\
9\end{array}$ & $\frac{\frac{8}{7}}{\frac{7}{1}}$ & $\begin{array}{r}20 \\
5 \\
4 \\
6 \\
2\end{array}$ & $\begin{array}{l}69 \\
18 \\
54 \\
22 \\
48\end{array}$ & $\begin{array}{r}135 \\
35 \\
58 \\
19 \\
23\end{array}$ & $\begin{array}{r}273 \\
76 \\
72 \\
109 \\
16\end{array}$ & $\frac{\frac{19}{14}}{5}$ & $\begin{array}{r}13 \\
2 \\
4 \\
3 \\
6\end{array}$ & $\begin{array}{r}43 \\
8 \\
33 \\
9 \\
13\end{array}$ & $\begin{array}{r}222 \\
9 \\
93 \\
14 \\
106\end{array}$ & $\begin{array}{r}281 \\
45 \\
103 \\
52 \\
81\end{array}$ \\
\hline $\begin{array}{l}\text { E.N. Central } \\
\text { Illinois } \\
\text { Indiana } \\
\text { Michigan } \\
\text { Ohio } \\
\text { Wisconsin }\end{array}$ & $\begin{array}{l}\frac{8}{3} \\
\frac{5}{-}\end{array}$ & $\begin{array}{l}7 \\
1 \\
1 \\
0 \\
2 \\
2\end{array}$ & $\begin{array}{r}31 \\
7 \\
7 \\
4 \\
14 \\
15\end{array}$ & $\begin{array}{l}\frac{57}{10} \\
16 \\
18 \\
13\end{array}$ & $\begin{array}{r}64 \\
18 \\
6 \\
-25 \\
15\end{array}$ & $\frac{\frac{15}{11}}{\frac{4}{-}}$ & $\begin{array}{r}17 \\
6 \\
1 \\
4 \\
3 \\
3\end{array}$ & $\begin{array}{r}78 \\
25 \\
56 \\
10 \\
11 \\
9\end{array}$ & $\begin{array}{r}175 \\
32 \\
30 \\
50 \\
43 \\
20\end{array}$ & $\begin{array}{r}184 \\
49 \\
15 \\
78 \\
14 \\
28\end{array}$ & $\begin{array}{l}7 \\
2 \\
2 \\
3 \\
-\end{array}$ & $\begin{array}{r}15 \\
3 \\
2 \\
4 \\
4 \\
1\end{array}$ & $\begin{array}{r}39 \\
10 \\
12 \\
10 \\
19 \\
8\end{array}$ & $\begin{array}{r}270 \\
56 \\
42 \\
70 \\
86 \\
16\end{array}$ & $\begin{array}{r}276 \\
83 \\
27 \\
74 \\
61 \\
31\end{array}$ \\
\hline $\begin{array}{l}\text { W.N. Central } \\
\text { lowa } \\
\text { Kansas } \\
\text { Minnesota } \\
\text { Missouri } \\
\text { Nebraska } \\
\text { North Dakota } \\
\text { South Dakota }\end{array}$ & $\begin{array}{l}2 \\
- \\
2 \\
1 \\
- \\
-\end{array}$ & $\begin{array}{l}7 \\
1 \\
1 \\
3 \\
2 \\
0 \\
0 \\
0\end{array}$ & $\begin{array}{r}39 \\
10 \\
4 \\
23 \\
7 \\
4 \\
2 \\
5\end{array}$ & $\begin{array}{r}38 \\
9 \\
28 \\
16 \\
2 \\
\frac{2}{1}\end{array}$ & $\begin{array}{r}44 \\
9 \\
6 \\
7 \\
12 \\
8 \\
-2\end{array}$ & $\begin{array}{l}1 \\
= \\
- \\
- \\
=\end{array}$ & $\begin{array}{r}38 \\
1 \\
4 \\
2 \\
22 \\
1 \\
0 \\
1\end{array}$ & $\begin{array}{r}64 \\
7 \\
20 \\
6 \\
45 \\
9 \\
9 \\
2 \\
17\end{array}$ & $\begin{array}{r}192 \\
3 \\
19 \\
20 \\
116 \\
18 \\
2 \\
14\end{array}$ & $\begin{array}{r}163 \\
35 \\
5 \\
11 \\
85 \\
19 \\
2 \\
6\end{array}$ & $\begin{array}{l}1 \\
\mathrm{~N} \\
- \\
- \\
-1 \\
-\end{array}$ & $\begin{array}{l}5 \\
0 \\
1 \\
1 \\
1 \\
0 \\
0 \\
0\end{array}$ & $\begin{array}{r}57 \\
0 \\
5 \\
52 \\
6 \\
4 \\
3 \\
2\end{array}$ & $\begin{array}{r}117 \\
\mathrm{~N} \\
30 \\
52 \\
19 \\
12 \\
3 \\
1\end{array}$ & $\begin{array}{r}78 \\
N \\
11 \\
26 \\
27 \\
7 \\
2 \\
5\end{array}$ \\
\hline $\begin{array}{l}\text { S. Atlantic } \\
\text { Delaware } \\
\text { District of Columbia } \\
\text { Florida } \\
\text { Georgia } \\
\text { Maryland } \\
\text { North Carolina } \\
\text { South Carolina } \\
\text { Virginia } \\
\text { West Virginia }\end{array}$ & $\begin{array}{l}\bar{z} \\
= \\
= \\
\frac{2}{z} \\
=\end{array}$ & $\begin{array}{l}7 \\
0 \\
0 \\
1 \\
0 \\
1 \\
1 \\
0 \\
2 \\
0\end{array}$ & $\begin{array}{r}41 \\
2 \\
1 \\
31 \\
31 \\
6 \\
5 \\
11 \\
2 \\
2 \\
9 \\
2\end{array}$ & $\begin{array}{l}\frac{23}{-} \\
\frac{15}{15} \\
\frac{-}{13} \\
2 \\
-\end{array}$ & $\begin{array}{l}65 \\
- \\
36 \\
8 \\
7 \\
9 \\
5 \\
-\end{array}$ & $\begin{array}{l}28 \\
- \\
12 \\
6 \\
3 \\
7 \\
- \\
-\end{array}$ & $\begin{array}{r}47 \\
0 \\
0 \\
21 \\
12 \\
2 \\
2 \\
2 \\
2 \\
2 \\
0\end{array}$ & $\begin{array}{r}116 \\
2 \\
2 \\
66 \\
37 \\
8 \\
22 \\
9 \\
9 \\
1\end{array}$ & $\begin{array}{r}542 \\
3 \\
231 \\
178 \\
33 \\
56 \\
32 \\
9 \\
-\end{array}$ & $\begin{array}{r}377 \\
2 \\
3 \\
156 \\
106 \\
17 \\
44 \\
31 \\
18 \\
-\end{array}$ & $\begin{array}{l}23 \\
- \\
8 \\
7 \\
8 \\
- \\
- \\
-\end{array}$ & $\begin{array}{r}19 \\
0 \\
0 \\
5 \\
4 \\
4 \\
1 \\
1 \\
2 \\
0\end{array}$ & \begin{tabular}{r|r}
39 \\
2 \\
2 \\
12 \\
9 \\
12 \\
13 \\
6 \\
11 \\
5
\end{tabular} & $\begin{array}{r}336 \\
1 \\
4 \\
86 \\
79 \\
78 \\
34 \\
24 \\
24 \\
6\end{array}$ & $\begin{array}{r}249 \\
2 \\
71 \\
55 \\
66 \\
25 \\
14 \\
13 \\
3\end{array}$ \\
\hline $\begin{array}{l}\text { E.S. Central } \\
\text { Alabama } \\
\text { Kentucky } \\
\text { Mississippi } \\
\text { Tennessee }\end{array}$ & $\begin{array}{l}- \\
- \\
-\end{array}$ & $\begin{array}{l}2 \\
0 \\
1 \\
0 \\
1\end{array}$ & $\begin{array}{r}12 \\
3 \\
9 \\
2 \\
4\end{array}$ & $\frac{\frac{9}{7}}{\frac{7}{19}}$ & $\begin{array}{r}14 \\
3 \\
3 \\
-8\end{array}$ & $\begin{array}{l}5 \\
5 \\
- \\
-\end{array}$ & $\begin{array}{r}17 \\
3 \\
6 \\
2 \\
4\end{array}$ & $\begin{array}{r}50 \\
20 \\
31 \\
7 \\
46\end{array}$ & $\begin{array}{r}121 \\
30 \\
50 \\
20 \\
21\end{array}$ & $\begin{array}{r}327 \\
70 \\
20 \\
25 \\
212\end{array}$ & $\frac{4}{\mathrm{~N}}$ & $\begin{array}{l}4 \\
0 \\
1 \\
0 \\
3\end{array}$ & $\begin{array}{r}10 \\
0 \\
4 \\
0 \\
9\end{array}$ & $\begin{array}{r}69 \\
N \\
15 \\
54\end{array}$ & $\begin{array}{r}58 \\
N \\
14 \\
44\end{array}$ \\
\hline $\begin{array}{l}\text { W.S. Central } \\
\text { Arkansas } \\
\text { Louisiana } \\
\text { Oklahoma } \\
\text { Texas }^{\S}\end{array}$ & $\begin{array}{l}- \\
- \\
-\end{array}$ & $\begin{array}{l}2 \\
0 \\
0 \\
0 \\
1\end{array}$ & $\begin{array}{r}32 \\
2 \\
2 \\
3 \\
32\end{array}$ & $\begin{array}{r}2 \\
1 \\
-1 \\
7\end{array}$ & $\begin{array}{r}14 \\
2 \\
6 \\
1 \\
5\end{array}$ & $\begin{array}{l}3 \\
1 \\
- \\
-2\end{array}$ & $\begin{array}{r}65 \\
1 \\
2 \\
10 \\
50\end{array}$ & $\begin{array}{r}244 \\
9 \\
11 \\
41 \\
237\end{array}$ & $\begin{array}{r}211 \\
24 \\
28 \\
23 \\
136\end{array}$ & $\begin{array}{r}569 \\
14 \\
35 \\
117 \\
403\end{array}$ & $\begin{array}{l}- \\
\overline{-} \\
-\end{array}$ & $\begin{array}{l}6 \\
0 \\
0 \\
2 \\
3\end{array}$ & $\begin{array}{r}48 \\
2 \\
2 \\
12 \\
41\end{array}$ & $\begin{array}{r}79 \\
3 \\
5 \\
51 \\
20\end{array}$ & $\begin{array}{r}79 \\
6 \\
4 \\
46 \\
23\end{array}$ \\
\hline $\begin{array}{l}\text { Mountain } \\
\text { Arizona } \\
\text { Colorado } \\
\text { Idaho } \\
\text { Montana } \\
\text { Nevada } \\
\text { New Mexico } \\
\text { Utah } \\
\text { Wyoming }\end{array}$ & $\begin{array}{l}2 \\
2 \\
-1 \\
- \\
- \\
- \\
-\end{array}$ & $\begin{array}{l}5 \\
0 \\
1 \\
1 \\
0 \\
0 \\
0 \\
1 \\
0\end{array}$ & $\begin{array}{r}16 \\
4 \\
6 \\
8 \\
2 \\
3 \\
3 \\
7 \\
3\end{array}$ & $\begin{array}{r}25 \\
10 \\
11 \\
4 \\
- \\
-2 \\
2 \\
-\end{array}$ & $\begin{array}{r}42 \\
4 \\
10 \\
7 \\
1 \\
9 \\
2 \\
8 \\
1\end{array}$ & $\begin{array}{r}11 \\
3 \\
7 \\
- \\
- \\
- \\
-1 \\
-\end{array}$ & $\begin{array}{r}17 \\
9 \\
3 \\
0 \\
0 \\
1 \\
2 \\
1 \\
0\end{array}$ & $\begin{array}{r}48 \\
29 \\
18 \\
4 \\
1 \\
6 \\
9 \\
4 \\
1\end{array}$ & $\begin{array}{r}164 \\
87 \\
28 \\
4 \\
12 \\
19 \\
13 \\
1\end{array}$ & $\begin{array}{r}140 \\
59 \\
23 \\
1 \\
23 \\
23 \\
11 \\
-\end{array}$ & $\begin{array}{r}14 \\
7 \\
5 \\
- \\
- \\
1 \\
1 \\
-\end{array}$ & $\begin{array}{r}12 \\
4 \\
3 \\
0 \\
0 \\
0 \\
1 \\
2 \\
0\end{array}$ & $\begin{array}{r}43 \\
28 \\
10 \\
2 \\
0 \\
6 \\
6 \\
6 \\
1\end{array}$ & $\begin{array}{r}240 \\
126 \\
63 \\
3 \\
- \\
- \\
22 \\
24 \\
2\end{array}$ & $\begin{array}{r}212 \\
84 \\
77 \\
1 \\
- \\
22 \\
27 \\
1\end{array}$ \\
\hline $\begin{array}{l}\text { Pacific } \\
\text { Alaska } \\
\text { California } \\
\text { Hawaii } \\
\text { Oregon } \\
\text { Washington }\end{array}$ & $\frac{\frac{2}{2}}{\frac{1}{1}}$ & $\begin{array}{l}6 \\
0 \\
1 \\
0 \\
2 \\
1\end{array}$ & $\begin{array}{r}52 \\
2 \\
11 \\
4 \\
47 \\
41\end{array}$ & $\begin{array}{r}27 \\
19 \\
2 \\
14 \\
6\end{array}$ & $\begin{array}{r}19 \\
2 \\
8 \\
3 \\
1 \\
5\end{array}$ & $\begin{array}{r}19 \\
1 \\
12 \\
2 \\
4\end{array}$ & $\begin{array}{r}39 \\
0 \\
32 \\
1 \\
1 \\
2\end{array}$ & $\begin{array}{r}145 \\
1 \\
103 \\
4 \\
28 \\
41\end{array}$ & $\begin{array}{r}367 \\
2 \\
269 \\
10 \\
51 \\
35\end{array}$ & $\begin{array}{r}450 \\
6 \\
402 \\
7 \\
24 \\
11\end{array}$ & $\begin{array}{l}1 \\
- \\
1 \\
N \\
N\end{array}$ & $\begin{array}{l}2 \\
0 \\
0 \\
2 \\
0 \\
0\end{array}$ & $\begin{array}{l}8 \\
0 \\
0 \\
8 \\
0 \\
0\end{array}$ & $\begin{array}{l}21 \\
\overline{-} \\
21 \\
N \\
N\end{array}$ & $\begin{array}{l}28 \\
\\
28 \\
N \\
N\end{array}$ \\
\hline $\begin{array}{l}\text { American Samoa } \\
\text { C.N.M.I. } \\
\text { Guam } \\
\text { Puerto Rico } \\
\text { U.S. Virgin Islands }\end{array}$ & $\begin{array}{l}U \\
\\
-\end{array}$ & $\begin{array}{l}0 \\
0 \\
0 \\
0 \\
0\end{array}$ & $\begin{array}{l}0 \\
0 \\
0 \\
1 \\
0\end{array}$ & $\begin{array}{l}U \\
\frac{U}{-} \\
-\end{array}$ & $\frac{U}{\frac{U}{1}}$ & $\begin{array}{l}U \\
\frac{U}{-} \\
-\end{array}$ & $\begin{array}{l}0 \\
0 \\
0 \\
0 \\
0\end{array}$ & $\begin{array}{l}2 \\
0 \\
0 \\
1 \\
0\end{array}$ & $\begin{array}{l}U \\
\\
-\end{array}$ & $\begin{array}{r}1 \\
U \\
1 \\
-\end{array}$ & $\frac{U}{\frac{U}{N}}$ & $\begin{array}{l}0 \\
0 \\
0 \\
0 \\
0\end{array}$ & $\begin{array}{l}0 \\
0 \\
0 \\
0 \\
0\end{array}$ & $\frac{U}{\frac{U}{N}}$ & $\frac{U}{\mathrm{U}}$ \\
\hline
\end{tabular}

C.N.M.I.: Commonwealth of Northern Mariana Islands.

U: Unavailable. $\quad$-: No reported cases. N: Not notifiable.

Cum: Cumulative year-to-date counts.

Med: Median

Max: Maximum. * Incidence data for reporting years 2005 and 2006 are provisional.

$\dagger$ Includes E. coli O157: H7; Shiga toxin positive, serogroup non-0157; and Shiga toxin positive, not serogrouped.

${ }^{\S}$ Contains data reported through the National Electronic Disease Surveillance System (NEDSS). 
TABLE II. (Continued) Provisional cases of selected notifiable diseases, United States, weeks ending April 1, 2006, and April 2, 2005 (13th Week)*

\begin{tabular}{|c|c|c|c|c|c|c|c|c|c|c|c|c|c|c|c|}
\hline \multirow[b]{3}{*}{ Reporting area } & \multicolumn{5}{|c|}{$\begin{array}{c}\text { Streptococcus pneumoniae, invasive disease } \\
\text { Drug resistant, all ages }\end{array}$} & \multicolumn{5}{|c|}{ Syphilis, primary and secondary } & \multicolumn{5}{|c|}{ Varicella (chickenpox) } \\
\hline & \multirow{2}{*}{$\begin{array}{c}\text { Current } \\
\text { week }\end{array}$} & \multicolumn{2}{|c|}{$\begin{array}{l}\text { Previous } \\
52 \text { weeks }\end{array}$} & \multirow{2}{*}{$\begin{array}{l}\text { Cum } \\
2006\end{array}$} & \multirow{2}{*}{$\begin{array}{l}\text { Cum } \\
2005\end{array}$} & \multirow{2}{*}{$\begin{array}{c}\text { Current } \\
\text { week }\end{array}$} & \multicolumn{2}{|c|}{$\begin{array}{l}\text { Previous } \\
52 \text { weeks }\end{array}$} & \multirow{2}{*}{$\begin{array}{l}\text { Cum } \\
2006\end{array}$} & \multirow{2}{*}{$\begin{array}{l}\text { Cum } \\
2005\end{array}$} & \multirow{2}{*}{$\begin{array}{c}\text { Current } \\
\text { week }\end{array}$} & \multicolumn{2}{|c|}{$\begin{array}{l}\text { Previous } \\
52 \text { weeks }\end{array}$} & \multirow{2}{*}{$\begin{array}{l}\text { Cum } \\
2006 \\
\end{array}$} & \multirow{2}{*}{$\begin{array}{l}\text { Cum } \\
2005 \\
\end{array}$} \\
\hline & & Med & $\operatorname{Max}$ & & & & Med & $\operatorname{Max}$ & & & & Med & Max & & \\
\hline United States & 49 & 49 & 124 & 840 & 854 & 74 & 171 & 299 & 1,683 & 1,828 & 901 & 638 & 2,988 & 12,424 & 6,982 \\
\hline $\begin{array}{l}\text { New England } \\
\text { Connecticut } \\
\text { Maine } \\
\text { Massachusetts } \\
\text { New Hampshire } \\
\text { Rhode Island } \\
\text { Vermont }^{\dagger}\end{array}$ & $\begin{array}{l}\bar{U} \\
\mathrm{~N} \\
- \\
- \\
-\end{array}$ & $\begin{array}{l}1 \\
0 \\
0 \\
1 \\
0 \\
0 \\
0\end{array}$ & $\begin{array}{r}14 \\
0 \\
0 \\
6 \\
0 \\
9 \\
2\end{array}$ & $\begin{array}{c}7 \\
U \\
N \\
- \\
1 \\
6\end{array}$ & $\begin{array}{r}43 \\
\text { N } \\
40 \\
- \\
3\end{array}$ & $\begin{array}{l}\frac{5}{-} \\
\frac{3}{2} \\
-\end{array}$ & $\begin{array}{l}4 \\
0 \\
0 \\
2 \\
0 \\
0 \\
0\end{array}$ & $\begin{array}{r}17 \\
11 \\
2 \\
5 \\
2 \\
6 \\
1\end{array}$ & $\begin{array}{r}45 \\
4 \\
3 \\
31 \\
4 \\
3 \\
\end{array}$ & $\begin{array}{r}47 \\
1 \\
1 \\
40 \\
2 \\
3 \\
-\end{array}$ & $\begin{array}{r}12 \\
U \\
\frac{2}{7} \\
\frac{7}{3}\end{array}$ & $\begin{array}{r}35 \\
0 \\
6 \\
18 \\
5 \\
0 \\
3\end{array}$ & $\begin{array}{r}1,130 \\
0 \\
20 \\
86 \\
1,110 \\
0 \\
25\end{array}$ & $\begin{array}{r}350 \\
U \\
85 \\
2 \\
95 \\
168\end{array}$ & $\begin{array}{r}824 \\
U \\
88 \\
719 \\
\\
17\end{array}$ \\
\hline $\begin{array}{l}\text { Mid. Atlantic } \\
\text { New Jersey } \\
\text { New York (Upstate) } \\
\text { New York City } \\
\text { Pennsylvania }\end{array}$ & $\begin{array}{l}6 \\
N \\
4 \\
U \\
2\end{array}$ & $\begin{array}{l}2 \\
0 \\
1 \\
0 \\
2\end{array}$ & $\begin{array}{r}14 \\
0 \\
10 \\
0 \\
9\end{array}$ & $\begin{array}{r}37 \\
N \\
9 \\
U \\
28\end{array}$ & $\begin{array}{r}86 \\
N \\
35 \\
U \\
51\end{array}$ & $\begin{array}{r}10 \\
3 \\
1 \\
2 \\
4\end{array}$ & $\begin{array}{r}20 \\
2 \\
2 \\
11 \\
4\end{array}$ & $\begin{array}{r}33 \\
7 \\
15 \\
21 \\
8\end{array}$ & $\begin{array}{r}164 \\
38 \\
31 \\
45 \\
50\end{array}$ & $\begin{array}{r}238 \\
33 \\
14 \\
155 \\
36\end{array}$ & $\frac{106}{-}$ & $\begin{array}{r}117 \\
0 \\
0 \\
0 \\
117\end{array}$ & $\begin{array}{r}182 \\
0 \\
0 \\
0 \\
182\end{array}$ & $\begin{array}{r}\frac{1,629}{-} \\
\frac{-}{1,629}\end{array}$ & $\frac{1,320}{-}$ \\
\hline $\begin{array}{l}\text { E.N. Central } \\
\text { Illinois } \\
\text { Indiana } \\
\text { Michigan } \\
\text { Ohio } \\
\text { Wisconsin }\end{array}$ & $\begin{array}{l}\frac{13}{7} \\
\frac{7}{6} \\
\mathrm{~N}\end{array}$ & $\begin{array}{r}12 \\
0 \\
3 \\
1 \\
7 \\
0\end{array}$ & $\begin{array}{r}37 \\
2 \\
19 \\
4 \\
32 \\
0\end{array}$ & $\begin{array}{r}214 \\
7 \\
50 \\
9 \\
148 \\
\mathrm{~N}\end{array}$ & $\begin{array}{r}187 \\
51 \\
14 \\
122 \\
\mathrm{~N}\end{array}$ & $\begin{array}{r}13 \\
5 \\
2 \\
3 \\
3 \\
-\end{array}$ & $\begin{array}{r}19 \\
9 \\
1 \\
2 \\
4 \\
1\end{array}$ & $\begin{array}{r}42 \\
32 \\
5 \\
8 \\
11 \\
3\end{array}$ & $\begin{array}{r}217 \\
85 \\
20 \\
39 \\
61 \\
12\end{array}$ & $\begin{array}{r}125 \\
34 \\
15 \\
16 \\
53 \\
7\end{array}$ & $\begin{array}{r}380 \\
N \\
81 \\
299 \\
-\end{array}$ & $\begin{array}{r}148 \\
1 \\
0 \\
86 \\
33 \\
7\end{array}$ & $\begin{array}{r}533 \\
5 \\
347 \\
231 \\
382 \\
27\end{array}$ & $\begin{array}{r}5,094 \\
4 \\
N \\
1,456 \\
3,530 \\
104\end{array}$ & $\begin{array}{r}1,992 \\
22 \\
\mathrm{~N} \\
1,235 \\
559 \\
176\end{array}$ \\
\hline $\begin{array}{l}\text { W.N. Central } \\
\text { lowa } \\
\text { Kansas } \\
\text { Minnesota } \\
\text { Missouri } \\
\text { Nebraska }^{\dagger} \\
\text { North Dakota } \\
\text { South Dakota }\end{array}$ & $\begin{array}{l}\bar{N} \\
N \\
- \\
- \\
-\end{array}$ & $\begin{array}{l}1 \\
0 \\
0 \\
0 \\
0 \\
0 \\
0 \\
0\end{array}$ & $\begin{array}{r}15 \\
0 \\
0 \\
15 \\
3 \\
1 \\
1 \\
1\end{array}$ & $\begin{array}{r}15 \\
\mathrm{~N} \\
\mathrm{~N} \\
15 \\
- \\
-\end{array}$ & $\begin{array}{r}13 \\
\mathrm{~N} \\
\mathrm{~N} \\
12 \\
\frac{1}{-} \\
1\end{array}$ & $\begin{array}{l}\frac{2}{1} \\
-\frac{1}{1} \\
- \\
-\end{array}$ & $\begin{array}{l}5 \\
0 \\
0 \\
1 \\
2 \\
0 \\
0 \\
0\end{array}$ & $\begin{array}{l}9 \\
1 \\
2 \\
5 \\
8 \\
1 \\
1 \\
1\end{array}$ & $\begin{array}{r}41 \\
2 \\
7 \\
6 \\
25 \\
1 \\
-\end{array}$ & $\begin{array}{r}58 \\
3 \\
5 \\
12 \\
37 \\
1 \\
-\end{array}$ & $\begin{array}{l}60 \\
\mathrm{~N} \\
- \\
58 \\
-\end{array}$ & $\begin{array}{r}15 \\
0 \\
0 \\
0 \\
11 \\
0 \\
0 \\
1\end{array}$ & $\begin{array}{r}73 \\
0 \\
0 \\
0 \\
72 \\
1 \\
25 \\
23\end{array}$ & $\begin{array}{r}557 \\
\mathrm{~N} \\
- \\
- \\
528 \\
- \\
13 \\
16\end{array}$ & $\begin{array}{r}41 \\
\mathrm{~N} \\
- \\
2 \\
9 \\
30\end{array}$ \\
\hline $\begin{array}{l}\text { S. Atlantic } \\
\text { Delaware } \\
\text { District of Columbia } \\
\text { Florida } \\
\text { Georgia } \\
\text { Maryland } \\
\text { North Carolina }^{\text {South Carolina }}{ }^{\dagger} \\
\text { Virginia }^{\dagger} \\
\text { West Virginia }^{\text {Wesia }}\end{array}$ & $\begin{array}{r}24 \\
1 \\
15 \\
5 \\
\frac{\mathrm{N}}{\mathrm{N}} \\
\mathrm{N} \\
3\end{array}$ & $\begin{array}{r}21 \\
0 \\
0 \\
11 \\
5 \\
0 \\
0 \\
0 \\
0 \\
2\end{array}$ & $\begin{array}{r}42 \\
2 \\
4 \\
34 \\
19 \\
0 \\
0 \\
0 \\
0 \\
10\end{array}$ & $\begin{array}{r}436 \\
\frac{14}{246} \\
145 \\
\frac{N}{N} \\
\frac{N}{31}\end{array}$ & $\begin{array}{r}371 \\
\frac{1}{10} \\
194 \\
141 \\
\frac{\mathrm{N}}{\mathrm{N}} \\
\mathrm{N} \\
26\end{array}$ & $\begin{array}{r}27 \\
1 \\
9 \\
2 \\
8 \\
4 \\
-3 \\
-\end{array}$ & $\begin{array}{r}43 \\
0 \\
2 \\
15 \\
8 \\
5 \\
5 \\
1 \\
3 \\
0\end{array}$ & $\begin{array}{r}178 \\
2 \\
9 \\
29 \\
137 \\
19 \\
17 \\
7 \\
12 \\
1\end{array}$ & $\begin{array}{r}436 \\
8 \\
24 \\
174 \\
33 \\
67 \\
75 \\
18 \\
37 \\
\end{array}$ & $\begin{array}{r}431 \\
2 \\
29 \\
181 \\
52 \\
72 \\
58 \\
16 \\
20 \\
1\end{array}$ & $\begin{array}{l}92 \\
- \\
- \\
- \\
- \\
- \\
4 \\
59 \\
29\end{array}$ & $\begin{array}{r}53 \\
1 \\
0 \\
0 \\
0 \\
0 \\
0 \\
12 \\
13 \\
19\end{array}$ & $\begin{array}{r}810 \\
5 \\
6 \\
0 \\
0 \\
0 \\
0 \\
43 \\
790 \\
70\end{array}$ & $\begin{array}{r}1,242 \\
24 \\
6 \\
- \\
- \\
- \\
- \\
240 \\
450 \\
522\end{array}$ & $\begin{array}{r}639 \\
7 \\
5 \\
- \\
- \\
- \\
158 \\
54 \\
415\end{array}$ \\
\hline $\begin{array}{l}\text { E.S. Central } \\
\text { Alabama }^{\dagger} \\
\text { Kentucky } \\
\text { Mississippi } \\
\text { Tennessee }^{\dagger}\end{array}$ & $\begin{array}{r}4 \\
\mathrm{~N} \\
1 \\
3\end{array}$ & $\begin{array}{l}4 \\
0 \\
0 \\
0 \\
3\end{array}$ & $\begin{array}{r}14 \\
0 \\
5 \\
0 \\
13\end{array}$ & $\begin{array}{r}71 \\
N \\
9 \\
62\end{array}$ & $\begin{array}{r}51 \\
N \\
9 \\
42\end{array}$ & $\begin{array}{r}9 \\
7 \\
- \\
2\end{array}$ & $\begin{array}{r}10 \\
3 \\
1 \\
0 \\
4\end{array}$ & $\begin{array}{r}20 \\
12 \\
5 \\
5 \\
11\end{array}$ & $\begin{array}{r}141 \\
76 \\
11 \\
11 \\
43\end{array}$ & $\begin{array}{r}114 \\
53 \\
6 \\
15 \\
40\end{array}$ & $\frac{-}{\frac{N}{N}}$ & $\begin{array}{l}0 \\
0 \\
0 \\
0 \\
0\end{array}$ & $\begin{array}{l}0 \\
0 \\
0 \\
0 \\
0\end{array}$ & $\frac{-}{\bar{N}}$ & $\frac{-}{\mathrm{N}}$ \\
\hline $\begin{array}{l}\text { W.S. Central } \\
\text { Arkansas } \\
\text { Louisiana } \\
\text { Oklahoma } \\
\text { Texas }^{\dagger}\end{array}$ & $\begin{array}{l}- \\
\overline{-} \\
\mathrm{N}\end{array}$ & $\begin{array}{l}1 \\
0 \\
1 \\
0 \\
0\end{array}$ & $\begin{array}{l}7 \\
3 \\
5 \\
0 \\
0\end{array}$ & $\begin{array}{r}31 \\
6 \\
25 \\
N \\
N\end{array}$ & $\begin{array}{r}71 \\
6 \\
65 \\
N \\
N\end{array}$ & $\begin{array}{r}4 \\
1 \\
1 \\
2 \\
-\end{array}$ & $\begin{array}{r}24 \\
1 \\
3 \\
1 \\
17\end{array}$ & $\begin{array}{r}37 \\
6 \\
17 \\
6 \\
27\end{array}$ & $\begin{array}{r}288 \\
25 \\
18 \\
20 \\
225\end{array}$ & $\begin{array}{r}292 \\
12 \\
37 \\
11 \\
232\end{array}$ & $\begin{array}{r}190 \\
2 \\
- \\
188\end{array}$ & $\begin{array}{r}152 \\
0 \\
1 \\
0 \\
148\end{array}$ & $\begin{array}{r}1,666 \\
39 \\
19 \\
0 \\
1,634\end{array}$ & $\begin{array}{r}2,552 \\
155 \\
80 \\
-2,317\end{array}$ & $\frac{1,102}{\frac{65}{2}}$ \\
\hline $\begin{array}{l}\text { Mountain } \\
\text { Arizona } \\
\text { Colorado } \\
\text { Idaho }^{\dagger} \\
\text { Montana } \text { Nevada }^{\dagger} \\
\text { New Mexico } \\
\text { Utah } \\
\text { Wyoming }\end{array}$ & $\begin{array}{l}2 \\
N \\
N \\
N \\
- \\
- \\
- \\
2\end{array}$ & $\begin{array}{l}1 \\
0 \\
0 \\
0 \\
0 \\
0 \\
0 \\
0 \\
0\end{array}$ & $\begin{array}{r}27 \\
0 \\
0 \\
0 \\
1 \\
27 \\
0 \\
6 \\
3\end{array}$ & $\begin{array}{r}29 \\
N \\
N \\
N \\
1 \\
\frac{1}{15} \\
13\end{array}$ & $\begin{array}{r}32 \\
N \\
N \\
N \\
1 \\
\frac{1}{19} \\
12\end{array}$ & $\begin{array}{l}3 \\
3 \\
- \\
- \\
- \\
- \\
-\end{array}$ & $\begin{array}{l}8 \\
3 \\
1 \\
0 \\
0 \\
2 \\
1 \\
0 \\
0\end{array}$ & $\begin{array}{r}17 \\
13 \\
3 \\
3 \\
1 \\
7 \\
3 \\
1 \\
0\end{array}$ & $\begin{array}{r}85 \\
52 \\
7 \\
1 \\
-19 \\
5 \\
1 \\
-\end{array}$ & $\begin{array}{r}103 \\
33 \\
17 \\
6 \\
5 \\
25 \\
14 \\
3 \\
-\end{array}$ & $\begin{array}{l}\frac{61}{22} \\
- \\
- \\
5 \\
34 \\
-\end{array}$ & $\begin{array}{r}48 \\
0 \\
35 \\
0 \\
0 \\
0 \\
3 \\
8 \\
0\end{array}$ & $\begin{array}{r}130 \\
0 \\
74 \\
0 \\
0 \\
2 \\
24 \\
55 \\
3\end{array}$ & $\begin{array}{r}1,000 \\
582 \\
- \\
- \\
- \\
139 \\
271 \\
8\end{array}$ & $\begin{array}{r}1,064 \\
725 \\
- \\
- \\
- \\
82 \\
218 \\
39\end{array}$ \\
\hline $\begin{array}{l}\text { Pacific } \\
\text { Alaska } \\
\text { California } \\
\text { Hawaii } \\
\text { Oregon }^{\dagger} \\
\text { Washington }\end{array}$ & $\begin{array}{l}-\bar{c} \\
\frac{\mathrm{N}}{\mathrm{N}} \\
\mathrm{N}\end{array}$ & $\begin{array}{l}0 \\
0 \\
0 \\
0 \\
0 \\
0\end{array}$ & $\begin{array}{l}0 \\
0 \\
0 \\
0 \\
0 \\
0\end{array}$ & $\begin{array}{l}- \\
\frac{N}{N} \\
N \\
N\end{array}$ & $\begin{array}{l}- \\
\bar{N} \\
\bar{N} \\
N\end{array}$ & $\begin{array}{l}1 \\
-1 \\
- \\
-\end{array}$ & $\begin{array}{r}34 \\
0 \\
28 \\
0 \\
0 \\
2\end{array}$ & $\begin{array}{r}56 \\
4 \\
54 \\
54 \\
2 \\
6 \\
11\end{array}$ & $\begin{array}{r}266 \\
4 \\
197 \\
6 \\
4 \\
45\end{array}$ & $\begin{array}{r}420 \\
3 \\
368 \\
1 \\
7 \\
41\end{array}$ & $\begin{array}{l}- \\
- \\
N \\
N \\
N\end{array}$ & $\begin{array}{l}0 \\
0 \\
0 \\
0 \\
0 \\
0\end{array}$ & $\begin{array}{l}0 \\
0 \\
0 \\
0 \\
0 \\
0\end{array}$ & $\begin{array}{l}- \\
- \\
N \\
N \\
N\end{array}$ & $\begin{array}{l}- \\
- \\
N \\
N \\
N\end{array}$ \\
\hline $\begin{array}{l}\text { American Samoa } \\
\text { C.N.M.I. } \\
\text { Guam } \\
\text { Puerto Rico } \\
\text { U.S. Virgin Islands }\end{array}$ & $\begin{array}{l}- \\
\bar{N} \\
-\end{array}$ & $\begin{array}{l}0 \\
0 \\
0 \\
0 \\
0\end{array}$ & $\begin{array}{l}0 \\
0 \\
0 \\
0 \\
0\end{array}$ & $\begin{array}{l}- \\
\bar{N} \\
-\end{array}$ & $\begin{array}{l}- \\
\bar{N} \\
-\end{array}$ & $\frac{U}{U}$ & $\begin{array}{l}0 \\
0 \\
0 \\
4 \\
0\end{array}$ & $\begin{array}{r}0 \\
0 \\
0 \\
16 \\
0\end{array}$ & $\begin{array}{c}U \\
\frac{U}{37} \\
-\end{array}$ & $\frac{U}{U} \frac{U}{35}$ & $\begin{array}{l}U \\
\frac{U}{2} \\
\end{array}$ & $\begin{array}{l}0 \\
0 \\
0 \\
6 \\
0\end{array}$ & $\begin{array}{r}0 \\
0 \\
0 \\
47 \\
0\end{array}$ & $\begin{array}{l}\mathrm{U} \\
\frac{\mathrm{U}}{42} \\
\end{array}$ & $\begin{array}{r}U \\
U \\
26 \\
160 \\
\end{array}$ \\
\hline
\end{tabular}

C.N.M.I.: Commonwealth of Northern Mariana Islands.

U: Unavailable. - No reported cases. N: Not notifiable.

Cum: Cumulative year-to-date counts.

Med: Median

Max: Maximum.

* Incidence data for reporting years 2005 and 2006 are provisional.

Contains data reported through the National Electronic Disease Surveillance System (NEDSS). 
TABLE II. (Continued) Provisional cases of selected notifiable diseases, United States, weeks ending April 1, 2006, and April 2, 2005 (13th Week)*

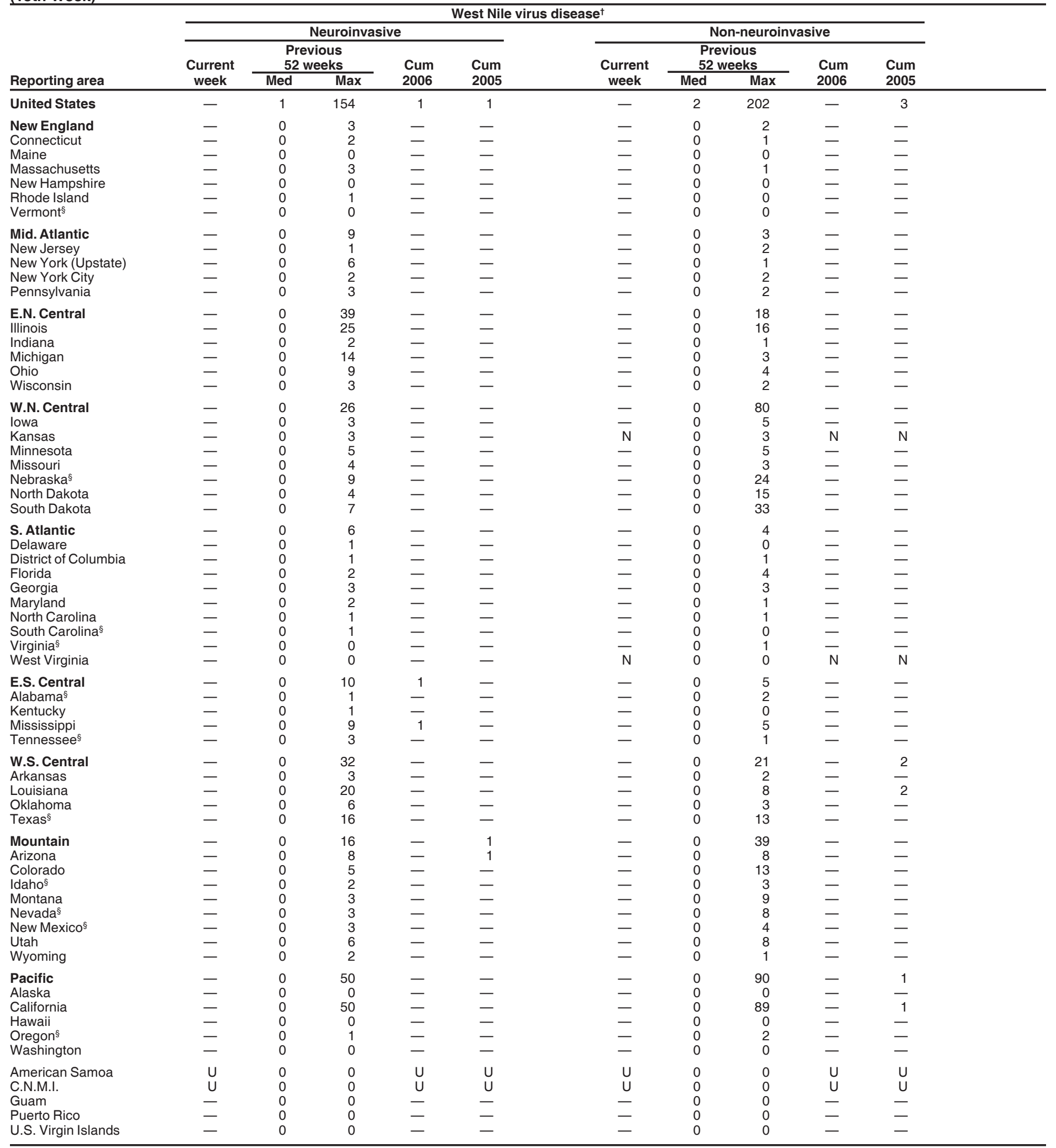

C.N.M.I.: Commonwealth of Northern Mariana Islands.

$\mathrm{U}$ : Unavailable. - No reported cases. N: Not notifiable.

* Incidence data for reporting years 2005 and 2006 are provisional.

† Updated weekly from reports to the Division of Vector-Borne Infectious Diseases, National Center for Infectious Diseases (ArboNet Surveillance).

$\S$ Contains data reported through the National Electronic Disease Surveillance System (NEDSS). 
TABLE III. Deaths in 122 U.S. cities, ${ }^{*}$ week ending April 1, 2006 (13th Week)

\begin{tabular}{|c|c|c|c|c|c|c|c|c|c|c|c|c|c|c|c|}
\hline \multirow[b]{2}{*}{ Reporting Area } & \multicolumn{6}{|c|}{ All causes, by age (years) } & \multirow[b]{2}{*}{$\begin{array}{l}\text { P\& }^{\dagger} \\
\text { Total }\end{array}$} & \multirow[b]{2}{*}{ Reporting Area } & \multicolumn{6}{|c|}{ All causes, by age (years) } & \multirow[b]{2}{*}{$\begin{array}{l}\text { P\&I }{ }^{\dagger} \\
\text { Total }\end{array}$} \\
\hline & $\begin{array}{c}\text { All } \\
\text { Ages }\end{array}$ & $\geq 65$ & $45-64$ & $25-44$ & $1-24$ & $<1$ & & & $\begin{array}{c}\text { All } \\
\text { Ages }\end{array}$ & $\geq 65$ & 45-64 & $25-44$ & $1-24$ & $<1$ & \\
\hline New England & 626 & 432 & 121 & 49 & 13 & 11 & 75 & S. Atlantic & 1,202 & 743 & 301 & 96 & 33 & 27 & 69 \\
\hline Boston, MA & 152 & 93 & 32 & 17 & 6 & 4 & 18 & Atlanta, GA & 75 & 39 & 26 & 8 & 1 & 1 & 5 \\
\hline Bridgeport, CT & 42 & 24 & 12 & 5 & 1 & - & 7 & Baltimore, MD & 166 & 101 & 44 & 14 & 5 & 2 & 15 \\
\hline Cambridge, MA & 25 & 18 & 6 & 1 & - & - & 1 & Charlotte, NC & 115 & 73 & 23 & 12 & 3 & 4 & 9 \\
\hline Fall River, MA & 31 & 23 & 5 & 2 & - & 1 & 2 & Jacksonville, FL & 170 & 105 & 36 & 13 & 7 & 8 & 2 \\
\hline Hartford, CT & 57 & 37 & 10 & 7 & 1 & 2 & 2 & Miami, FL & 90 & 55 & 21 & 10 & 2 & 2 & 3 \\
\hline Lowell, MA & 26 & 19 & 6 & 1 & - & - & 3 & Norfolk, VA & 60 & 37 & 19 & 2 & - & 2 & 1 \\
\hline Lynn, MA & 15 & 10 & 4 & 1 & - & - & 3 & Richmond, VA & 68 & 38 & 27 & 2 & - & 1 & 5 \\
\hline New Bedford, MA & 22 & 18 & 4 & - & - & - & 2 & Savannah, GA & 71 & 47 & 20 & 2 & 2 & - & 5 \\
\hline New Haven, CT & 33 & 26 & 3 & 2 & 1 & 1 & 8 & St. Petersburg, FL & 70 & 40 & 20 & 4 & 3 & 3 & 6 \\
\hline Providence, RI & 68 & 46 & 16 & 3 & 2 & 1 & 10 & Tampa, FL & 203 & 141 & 38 & 14 & 5 & 4 & 11 \\
\hline Somerville, MA & 7 & 6 & 1 & - & - & - & - & Washington, D.C. & 99 & 53 & 26 & 15 & 5 & - & 2 \\
\hline Springfield, MA & 47 & 33 & 8 & 4 & 1 & 1 & 4 & Wilmington, DE & 15 & 14 & 1 & - & - & - & 5 \\
\hline Waterbury, CT & 25 & 22 & - & 3 & - & - & 4 & & 966 & 615 & 234 & 55 & 34 & 28 & 89 \\
\hline Worcester, MA & 76 & 57 & 14 & 3 & 1 & 1 & 11 & $\begin{array}{l}\text { E.S. Central } \\
\text { Birmingham, AL }\end{array}$ & $\begin{array}{l}960 \\
150\end{array}$ & $\begin{array}{r}015 \\
92\end{array}$ & $\begin{array}{r}234 \\
35\end{array}$ & $\begin{array}{r}50 \\
7\end{array}$ & $\begin{array}{r}34 \\
7\end{array}$ & 9 & 14 \\
\hline Mid. Atlantic & 2,224 & 1,505 & 507 & 124 & 49 & 39 & 112 & Chattanooga, TN & 81 & 56 & 16 & 5 & 1 & 3 & 2 \\
\hline Albany, NY & 53 & 36 & 13 & 3 & 1 & - & 4 & Knoxville, TN & 72 & 45 & 17 & 9 & - & 1 & 3 \\
\hline Allentown, PA & 26 & 20 & 3 & 3 & - & - & 3 & Lexington, $\mathrm{KY}$ & 93 & 70 & 16 & 5 & - & 2 & 9 \\
\hline Buffalo, NY & 85 & 63 & 15 & 4 & 1 & 2 & 13 & Memphis, TN & 194 & 104 & 59 & 11 & 13 & 7 & 17 \\
\hline Camden, NJ & 36 & 24 & 6 & 2 & - & 4 & 3 & Mobile, AL & 126 & 88 & 26 & 5 & 4 & 3 & 16 \\
\hline Elizabeth, NJ & 22 & 16 & 5 & 1 & - & - & 2 & Montgomery, $\mathrm{AL}$ & 90 & 64 & 21 & 1 & 3 & 1 & 19 \\
\hline Erie, PA & 45 & 39 & 4 & 1 & 1 & - & 1 & Nashville, TN & 160 & 96 & 44 & 12 & 6 & 2 & 9 \\
\hline Jersey City, NJ & 40 & 30 & 8 & 1 & - & 1 & - & W.S. Central & 1,540 & 973 & 376 & 110 & 41 & 40 & 91 \\
\hline New York City, NY & 1,098 & 733 & 269 & 60 & 21 & 15 & 41 & $\begin{array}{l}\text { W.S. Central } \\
\text { Austin, TX }\end{array}$ & $\begin{array}{r}1,540 \\
102\end{array}$ & 62 & 25 & 7 & $\begin{array}{r}41 \\
2\end{array}$ & $\begin{array}{r}40 \\
6\end{array}$ & $\begin{array}{r}911 \\
6\end{array}$ \\
\hline Newark, NJ & 57 & 31 & 16 & 5 & 4 & 1 & 5 & $\begin{array}{l}\text { Austin, TX } \\
\text { Baton Bouge IA }\end{array}$ & & 25 & 7 & & & & $\begin{array}{l}0 \\
1\end{array}$ \\
\hline Paterson, NJ & 21 & 16 & 2 & 2 & 1 & - & 1 & & 38 & & & 5 & $\overline{3}$ & 1 & 1 \\
\hline Philadelphia, PA & 342 & 190 & 96 & 28 & 15 & 13 & 16 & Corpus Christi, TX & 67 & 44 & 15 & 4 & 3 & 1 & 3 \\
\hline Pittsburgh, $\mathrm{PA}^{\S}$ & 23 & 18 & 4 & 1 & - & - & 1 & Dallas, TX & 232 & 143 & 58 & 16 & 10 & 5 & 16 \\
\hline Reading, PA & 26 & 23 & 2 & 1 & - & - & 1 & El Paso, TX & 128 & 89 & 23 & 8 & 3 & 5 & 5 \\
\hline Rochester, NY & 135 & 105 & 23 & 3 & 2 & 2 & 5 & Fort Worth, TX & 116 & 82 & 22 & 4 & 2 & 6 & 9 \\
\hline Schenectady, NY & 13 & 9 & 3 & 1 & - & $\underline{-}$ & 1 & Houston, TX & 404 & 234 & 112 & 35 & 13 & 10 & 20 \\
\hline Scranton, PA & 28 & 22 & 5 & 1 & - & - & 1 & Little Rock, AR & 78 & 47 & 18 & 8 & 2 & 3 & 2 \\
\hline Syracuse, NY & 103 & 73 & 24 & 4 & 1 & 1 & 11 & New Orleans, LA & U & $U$ & $U$ & $U$ & $U$ & $U$ & $\mathrm{U}$ \\
\hline Trenton, NJ & 32 & 21 & $\begin{array}{r}24 \\
7\end{array}$ & $\begin{array}{l}4 \\
2\end{array}$ & 2 & -1 & $\begin{array}{r}11 \\
1\end{array}$ & San Antonio, TX & 202 & 144 & 41 & 15 & 2 & - & 18 \\
\hline Utica, NY & 19 & 16 & 2 & 1 & - & - & 1 & Shreveport, LA & 51 & 31 & 15 & 1 & 2 & 2 & 7 \\
\hline Yonkers, NY & 20 & 20 & - & - & - & - & $\overline{2}$ & Tulsa, OK & 122 & 72 & 40 & 7 & 2 & 1 & 4 \\
\hline E.N. Central & 2,238 & 1,479 & 524 & 146 & 46 & 43 & & Mountain & 1,077 & 718 & 212 & 85 & 44 & 17 & 93 \\
\hline Akron, $\mathrm{OH}$ & 54 & 32 & 13 & 6 & $\begin{array}{r}40 \\
2\end{array}$ & $\begin{array}{r}43 \\
1\end{array}$ & $\begin{array}{r}159 \\
?\end{array}$ & Albuquerque, NM & 161 & 110 & 34 & 12 & 5 & - & 14 \\
\hline Canton, $\mathrm{OH}$ & 40 & 34 & 6 & - & - & - & 2 & Boise, ID & 58 & 46 & 10 & 1 & - & 1 & 6 \\
\hline Chicago, IL & 339 & 196 & 98 & 28 & 8 & - & $\begin{array}{r}4 \\
2 ?\end{array}$ & Colorado Springs, CO & 73 & 52 & 15 & 4 & 1 & 1 & 7 \\
\hline Cincinnati, $\mathrm{OH}$ & 113 & 79 & 21 & $\begin{array}{r}20 \\
4\end{array}$ & 6 & 9 & 22 & Denver, CO & 104 & 68 & 17 & 10 & 6 & 3 & 9 \\
\hline Cleveland, $\mathrm{OH}$ & 228 & 164 & 49 & $\begin{array}{r}4 \\
11\end{array}$ & - & $\begin{array}{l}3 \\
4\end{array}$ & $\begin{array}{r}14 \\
7\end{array}$ & Las Vegas, NV & 292 & 198 & 63 & 22 & 6 & 3 & 22 \\
\hline Columbus, $\mathrm{OH}$ & 200 & 137 & 50 & 5 & 3 & $\begin{array}{l}4 \\
5\end{array}$ & 14 & Ogden, UT & 23 & 18 & 3 & 1 & - & 1 & - \\
\hline Dayton, $\mathrm{OH}$ & 151 & 109 & 25 & 14 & 3 & - & $\begin{array}{r}14 \\
4\end{array}$ & Phoenix, AZ & 225 & 126 & 43 & 24 & 24 & 7 & 18 \\
\hline Detroit, MI & 178 & 88 & 62 & 18 & 6 & 4 & $\begin{array}{r}4 \\
15\end{array}$ & Pueblo, CO & 25 & 22 & 2 & 1 & - & - & 2 \\
\hline Evansville, IN & 53 & 35 & 12 & 5 & 1 & - & $\begin{array}{r}15 \\
4\end{array}$ & Salt Like City, UT & 116 & 78 & 25 & 10 & 2 & 1 & 15 \\
\hline Fort Wayne, IN & 76 & 56 & 13 & 6 & 1 & - & $\begin{array}{l}4 \\
8\end{array}$ & Tucson, AZ & U & $U$ & $U$ & $U$ & $U$ & $U$ & U \\
\hline Gary, IN & 7 & 3 & 1 & 1 & 1 & 1 & - & Pacific & 1,981 & 1,359 & 417 & 117 & 45 & 43 & 205 \\
\hline Grand Rapids, MI & 67 & 45 & 12 & 3 & 4 & 3 & 11 & Berkeley, CA & 31 & 20 & 8 & 3 & - & - & 1 \\
\hline Indianapolis, IN & 239 & 163 & 48 & 16 & 4 & 8 & 13 & Fresno, CA & 50 & 35 & 13 & 1 & - & 1 & 7 \\
\hline Lansing, MI & 62 & 44 & 13 & 4 & 1 & - & 9 & Glendale, CA & 39 & 32 & 4 & 1 & 1 & 1 & 7 \\
\hline Milwaukee, WI & 107 & 67 & 32 & 7 & - & 1 & 7 & Honolulu, $\mathrm{HI}$ & 40 & 30 & 5 & 4 & - & 1 & - \\
\hline Peoria, IL & 40 & 19 & 15 & 3 & 1 & 2 & 8 & Long Beach, CA & 71 & 45 & 19 & 7 & - & - & 9 \\
\hline Rockford, IL & 48 & 39 & 8 & 1 & - & - & 4 & Los Angeles, CA & 545 & 351 & 115 & 55 & 9 & 15 & 59 \\
\hline South Bend, IN & 59 & 46 & 10 & 3 & - & - & 4 & Pasadena, CA & 38 & 32 & 2 & 3 & - & 1 & 8 \\
\hline Toledo, $\mathrm{OH}$ & 116 & 73 & 27 & 10 & 4 & 2 & 3 & Portland, OR & 142 & 102 & 29 & 5 & 5 & 1 & 7 \\
\hline Youngstown, $\mathrm{OH}$ & 61 & 50 & 9 & 1 & 1 & - & 6 & Sacramento, CA & 173 & 118 & 40 & 7 & 5 & 3 & 18 \\
\hline W.N. Central & 627 & 436 & 126 & 34 & 18 & 12 & 52 & San Diego, CA & 115 & 78 & 25 & 5 & 2 & 5 & 11 \\
\hline Des Moines, IA & 64 & 45 & 18 & - & 1 & 12 & 4 & San Francisco, CA & 118 & 74 & 33 & 4 & 2 & 5 & 11 \\
\hline Duluth, MN & 32 & 22 & 9 & 1 & - & - & $\begin{array}{l}4 \\
8\end{array}$ & San Jose, CA & 300 & 220 & 56 & 8 & $\overline{9}$ & 7 & 43 \\
\hline Kansas City, KS & 32 & 21 & 5 & 2 & 3 & 1 & 6 & Santa Cruz, CA & 22 & 16 & 6 & - & - & - & 2 \\
\hline Kansas City, MO & 87 & 56 & 22 & 6 & 2 & 1 & $\begin{array}{l}0 \\
7\end{array}$ & Seattle, WA & 129 & 92 & 26 & 5 & 4 & 2 & 7 \\
\hline Lincoln, NE & 41 & 36 & $\begin{array}{r}22 \\
4\end{array}$ & 1 & 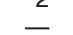 & - & 2 & Spokane, WA & 68 & 46 & 10 & 5 & 6 & 1 & 12 \\
\hline Minneapolis, MN & $\begin{array}{l}41 \\
75\end{array}$ & 46 & 16 & 7 & $\overline{3}$ & 3 & 9 & Tacoma, WA & 100 & 68 & 26 & 4 & 2 & - & 3 \\
\hline Omaha, NE & 93 & 69 & 14 & 5 & 4 & 1 & 6 & Total & $12,481^{* *}$ & 8,260 & 2,818 & 816 & 323 & 260 & 945 \\
\hline St. Louis, MO & 65 & 43 & 15 & 4 & - & 2 & 5 & & & & & & & & \\
\hline St. Paul, MN & 59 & 45 & 9 & 4 & - & 1 & 2 & & & & & & & & \\
\hline Wichita, KS & 79 & 53 & 14 & 4 & 5 & 3 & 3 & & & & & & & & \\
\hline
\end{tabular}

U: Unavailable. - $\quad$ No reported cases.

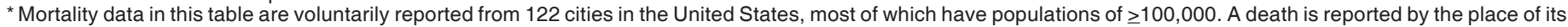
occurrence and by the week that the death certificate was filed. Fetal deaths are not included.

$\dagger$ Pneumonia and influenza.

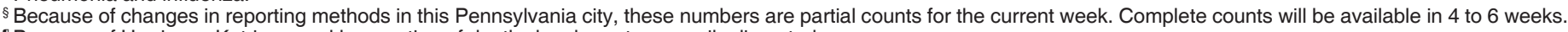

"Because of Hurricane Katrina, weekly reporting of deaths has been temporarily disrupted.

** Total includes unknown ages. 
FIGURE I. Selected notifiable disease reports, United States, comparison of provisional 4-week totals April 1, 2006, with historical data

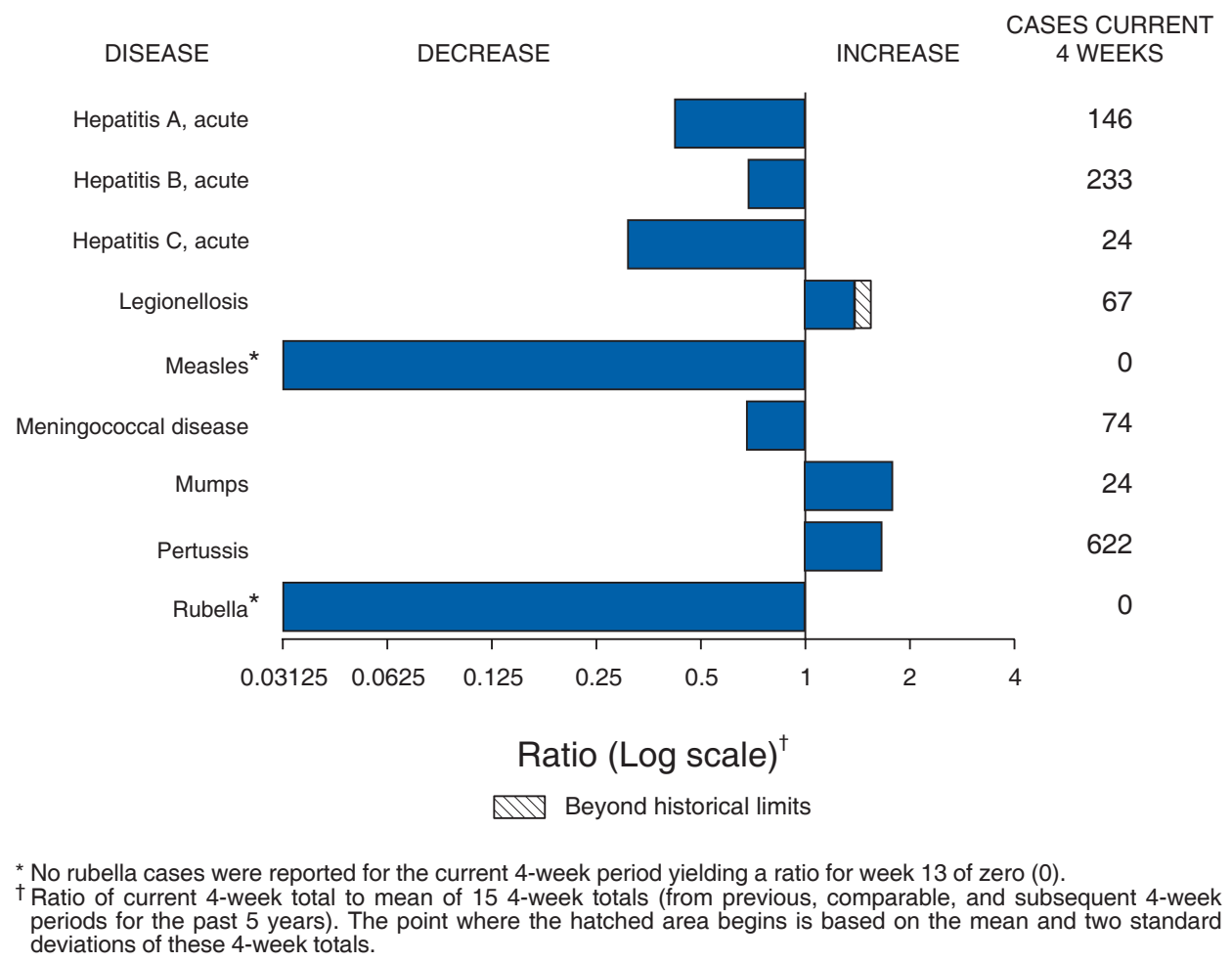


The Morbidity and Mortality Weekly Report (MMWR) Series is prepared by the Centers for Disease Control and Prevention (CDC) and is available free of charge in electronic format and on a paid subscription basis for paper copy. To receive an electronic copy each week, send an e-mail message to listserv@listserv.cdc.gov. The body content should read SUBscribe mmwr-toc. Electronic copy also is available from CDC's World-Wide Web server at http://www.cdc.gov/mmwr or from CDC's file transfer protocol server at ftp://ftp.cdc.gov/pub/publications/mmwr. To subscribe for paper copy, contact Superintendent of Documents, U.S. Government Printing Office, Washington, DC 20402; telephone 202-512-1800.

Data in the weekly MMWR are provisional, based on weekly reports to CDC by state health departments. The reporting week concludes at close of business on Friday; compiled data on a national basis are officially released to the public on the following Friday. Address inquiries about the $M M W R$ Series, including material to be considered for publication, to Editor, MMWR Series, Mailstop K-95, CDC, 1600 Clifton Rd., N.E., Atlanta, GA 30333; telephone 888-232-3228.

All material in the MMWR Series is in the public domain and may be used and reprinted without permission; citation as to source, however, is appreciated.

All MMWR references are available on the Internet at http://www.cdc.gov/mmwr. Use the search function to find specific articles.

Use of trade names and commercial sources is for identification only and does not imply endorsement by the U.S. Department of Health and Human Services.

References to non-CDC sites on the Internet are provided as a service to MMWR readers and do not constitute or imply endorsement of these organizations or their programs by CDC or the U.S. Department of Health and Human Services. CDC is not responsible for the content of these sites. URL addresses listed in $M M W R$ were current as of the date of publication.

预U.S. Government Printing Office: 2006-523-056/40036 Region IV ISSN: 0149-2195 